Leonardo Bíscaro Pereira

Avaliação do Perfil de Citocinas no Tecido Subcutâneo de Camundongos na Presença de Cimento Endodôntico 



\section{Avaliação do Perfil de Citocinas no Tecido Subcutâneo de Camundongos na Presença de Cimento Endodôntico}

Tese apresentada à Faculdade de Odontologia de Ribeirão Preto da Universidade de São Paulo, para obtenção do Título de Doutor em Ciências da Saúde. Programa: Odontopediatria Área de Concentração: Odontopediatria OrIentadora: Prof. Dra. Léa Assed Bezerra da Silva COORIENTADOR: Prof. Dr. Marcelo José Barbosa Silva

\section{Versão Corrigida}

Ribeirão Preto 


\section{AUTORIZAÇÃO PARA REPRODUÇÃo}

Autorizo a reprodução e divulgação total ou parcial deste trabalho, por qualquer meio convencional ou eletrônico, para fins de estudo e pesquisa, desde que citada a fonte.

Nota: A versão original desta tese encontra-se disponível na Biblioteca da unidade sede do Programa.

Ficha CATALOGRÁFica

Pereira, Leonardo Bíscaro

Avaliação do Perfil de Citocinas no Tecido Subcutâneo de Camundongos na Presença de Cimento Endodôntico, 2012

137 p. : il. ; $30 \mathrm{~cm}$

Tese de Doutorado, apresentada à Faculdade de Odontologia de Ribeirão Preto/USP. Área de Concentração: Odontopediatria

Orientadora: Léa Assed Bezerra da Silva

Coorientador: Marcelo José Barbosa Silva

1.Endodontia, 2. Cimentos endodônticos, 3. Citocinas, 4. Células Th1, 5.Células Th2, 6. Células Th17, 7. Tecido Subcutâneo, 8. Citometria de fluxo 
Pereira, LB. Avaliação do Perfil de Citocinas no Tecido Subcutâneo de Camundongos na Presença de Cimento Endodôntico

Tese apresentada à Faculdade de Odontologia de Ribeirão Preto da Universidade de São Paulo, para obtenção do Título de Doutor em Ciências da Saúde. Programa: Odontopediatria Área de concentração: Odontopediatria.

Data da defesa:

BANCA EXAMINADORA

Prof. Dr.

Instituição:

Julgamento:

Assinatura:

Prof. Dr.

Instituição:

Julgamento:

Assinatura:

Prof. Dr.

Instituição:

Julgamento:

Assinatura:

Prof. Dr.

Instituição:

Julgamento:

Assinatura:

Prof. Dr.

Instituição:

Julgamento: Assinatura: 



\section{Leonardo Bíscaro Pereira}

Dados Curriculares

Nascimento 21 de novembro de 1980 - Santa Fé do Sul/SP

Filiação Antonio Cassiano Pereira

Cleide Maria Bíscaro Pereira

1999-2002 Curso de Graduação

Faculdade de Odontologia de Ribeirão Preto da Universidade de São Paulo

2005-2007 Curso de Pós-Graduação "Lato Sensu'em Odontologia

Especialização em Endodontia

Faculdade de Odontologia Universidade Federal de Uberlândia-MG

2005-2007 Curso de Pós-Graduação (Mestrado) em Odontologia

Área de Concentração: Reabilitação Oral

Faculdade de Odontologia Universidade Federal de Uberlândia-MG

2009-2013 Curso de Pós-Graduação (Doutorado) em Ciências da Saúde

Programa: odontopediatria

Área de Concentração: Odontopediatria

Faculdade de Odontologia de Ribeirão Preto da Universidade de São Paulo

2012-Atual Professor das Disciplinas de Endodontia I e II

Curso de Odontologia da Faculdade Patos de Minas-MG 



\section{Dedico Este TRABALHO}

A minha esposa amada Daniella Cristina Borges, que esteve sempre ao meu lado me incentivando dando apoio e ajudando na execussão deste projeto.

Aos meus Pais Antonio Cassiano Pereira e Cleide Maria Bíscaro Pereira por terem me educado com ética responsabilidade e principalmente amor o que me permitiu ser a pessoa que sou hoje.

Aos meus irmãos, Cassiano Bíscaro Pereira e Fabrício Biscaro Pereira que mesmo a distância nunca deixaram de torcer por mim.

E a todos os meus familiares que sempre estiveram presentes na minha vida. 



\section{Agradecimentos Especiais}

À minha orientadora Profa. Dra Léa Assed Bezerra da Silva, professora do departamento de Clínica Infantil da Faculdade de Odontologia de Ribeirão Preto/USP, pelo apoio e conhecimentos transmitidos durante estes anos, sendo um exemplo de dedicação à docência.

Ao meu coorientador Dr Marcelo José Barbosa Silva, professor do Instituto de Ciências Biomédicas da Universidade Federal de Uberlândia. Quis o destino que nos tornássemos amigos para depois poder chamá-lo de professor. Quero sempre tê-lo como um exemplo de dedicação à pesquisa e à famíla. Obrigado por toda orientação, incentivo e ajuda e espero poder contar sempre com a sua amizade.

Ao Prof. Dr. Mário Roberto Leonardo, professor colaborador do departamento de Clínica Infantil da Faculdade de Odontologia de Ribeirão Preto/USP, por ter colaborado na execussão deste trabalho.

À Profa. Raquel Assed Bezerra Segato, professora do departamento de Clínica Infantil da Faculdade de Odontologia de Ribeirão Preto/USP, sempre disposta a ajudar no que fosse preciso.

À Profa. Dra. Lúcia Helena Faccioli, professora do departamento de Ciências Farmacêuticas da Faculdade de Ciências Farmacêutica de Ribeirão Preto/USP, pelo auxîlio no delineamento e execussão da fase laboratorial desta pesquisa.

Ao Dr Francisco Wanderley Garcia de Paula e Silva, Cirurgião Dentista do departamento de Clínica Infantil da Faculdade de Odontologia de Ribeirão Preto/USP. Obrigado pela ajuda e apoio durante a pesquisa.

Aos amigos do laboratório do departamento de Clínica Infantil da Faculdade de Odontologia de Ribeirão Preto/USP, Marco Antonio Dos Santos, Nilza Letícia Magalhães e Fátima Aparecida Rizoli. Sem a ajuda e dedicação de vocês com minhas amostras e o carinho com que sempre me receberam, a conclusão deste trabalho teria sido muito mais difícil. 
Ao amigo Prof. Dr. Paulo César Azevedo, professor aposentado da Ārea de Endodontia da Faculdade de Odontologia da Universidade Federal de Uberlândia, um dos principais responsáveis pela minha paixão pela Endodontia e pela docência.

Aos professores da Área de Endodontia da Faculdade de Odontologia da Universidade Federal de Uberlândia, Prof. Dr. João Carlos Gabrielli Biffi, Profa. Dra. Luciana Arantes Porto Carvalho, Prof. Dr. Cássio José Alves de Sousa, por permitirem que eu fizesse parte da equipe de professores dos cursos de especialização em Endodontia e pelo incentivo em seguir a carreira acadêmica.

À amiga Fernanda Regina Ribeiro Santos, pela amizade sincera e a companhia sempre alegre e divertida no biotério. 
À Universidade de São Paulo.

À Faculdade de Odontologia de Ribeirão Preto da Universidade de São Paulo, na pessoa do atual diretor Prof. Dr.Valdemar Mallet da Rocha Barros e da Vice-Diretora Profa. Dra. Léa Assed Bezerra da Silva.

À Coordenação do Curso de Pós-Graduação em Odontopediatria da Faculdade de Odontologia de Ribeirão Preto da Universidade de São Paulo, na pessoa da Profa. Dra. Léa Assed Bezerra da Silva e do Vice-Coordenador Prof. Dr. Paulo Nelson Filho.

À Universidade Federal de Uberlândia.

Ao Instituto de Ciências Biomédicas da UFU.

Ao Prof. Dr Tiago Wilson Patriarca Mineo professor do Instituto de Ciências Biomédicas da Universidade Federal de Uberlândia e responsável técnico do laboratório de Imunoparasitologia - UFU, por me receber de forma tão atenciosa e permitir que parte de minha pesquisa fosse realizada na instituição.

À Dra. Ana Cláudia Arantes Marquez Pajuaba, técnica de nível superior do Instituto de Ciências Biomédicas da Universidade Federal de Uberlânndia, pela colaboração atenciosa e indispensável na execussão e leitura da citometria de fluxo.

Aos professores do departamento de Clínica Infantil da Faculdade de Odontologia de Ribeirão Preto/USP, Profa. Dra. Aldevina Campos de Freitas, Profa. Dra. Alexandra Mussolino de Queiroz, Profa. Dra. Andiara De Rossi Daldegan, Profa Dra. Kranya Victoria Díaz Serrano, Profa. Dra. Léa Assed Bezerra da Silva, Profa. Dra. Maria Cristina Borsato, Prof. Dr. Paulo Nelson Filho, Profa. Dra. Raquel Assed Bezerra Segato e Profa Dra. Sada Assed. Obrigado pela minha formação durante os cursos de graduação e pós-graduação. 
Aos funcionários do departamento de Clínica Infantil da Faculdade de Odontologia de Ribeirão Preto/USP, Filomena Leli Placciti, Micheli Cristina Leite Rovanholo, Matheus Morelli Zanela e Dr. Marilia Pacífico Lucisano, pela colaboração e atenção dedicadas.

Aos colegas de curso de Pós-graduação em Odontopediatria da Faculdade de Odontologia de Ribeirão Preto/USP, por tudo o que apreendemos juntos neste período de convivência.

Às funcionárias da Secção de Pós-Graduação da Faculdade e Odontologia de Ribeirão Preto/USP, Isabel Cristina Galino Sola e Regiane Cristina Moi Sacilotto, pela atenção e carinho.

Aos colegas, professores e amigos da Faculdade de Patos de Minas - FPM; Prof. Me. Fernando Nascimento, Prof. Me. Marcelo Dias, Prof. Me. Marcos Bilharino de Mendonça, Profa. Ma. Daniella Cristina Borges, Profa. Ma. Dalila Viviane Barros, Profa Ma. Lia Dietrich, Prof. Me. Douglas Magalhães de Paula, Profa. Ma. Débora Andalécio, Prof. Alexandre Vianna e Prof. Henrique Cury, muito obrigado pela compreensão apoio e amizade. 


\section{LISTA DE FIGURAS}

Figura 1. (A) paquímetro digital utilizado para a padronização do comprimento dos tubos, (B) tubo de calibre 4 com uma das extremidades fechada, (C) tubo de calibre 6 com uma das extremidades fechada, (D) tubo de calibre 12, (E,F) implante com os tubos de calibre 4 seta vermelha, calibre 6 seta branca e calibre 12 seta amarela.

Figura 2. (A) seringa de $1 \mathrm{ml}$ com a extremidade cortada e disco diamantado montado em mandril para peça reta; (B) implante no interior do aplicador; (C) conjunto aplicador e implante embalados e esterilizados por óxido de etileno...............................................

Figura 3. (A) zona assépitica formada pela chama de três lamparinas; (B) esponja sendo embebida com $5 \mu$ le PBS fisiológico ou da solução de Lipopolissacarideo; (C) tubo sendo preenchido com o cimento endodôntico a ser testado; (D) implante pronto para instalação.........

Figura 4. (A) zona assépitica formada pela chama de três lamparinas; (B) esponja sendo embebida com $5 \mu$ le PBS fisiológico ou da solução de Lipopolissacarideo; (C) tubo sendo preenchido com o cimento endodôntico a ser testado; (D) implante pronto para instalação.........

Figura 5. (A) tecido removido de formato retangular com o implante situado ao centro; (B) remoção do implante pela base; (C) remoção do excesso de tecido; (D) tecido correspondente ao implante.

Figura 6. (A) tecido removido de formato retangular com o implante situado ao centro; (B) foto esquemática demosntrando a posição do implante em relação ao tecido.

Figura 7. (A) amostra em $0.5 \mathrm{ml}$ de uma solução formada por $0.480 \mathrm{ml}$ de tampão de lise RIPA associado a $0.020 \mathrm{ml}$ da solução de inibidor de protease; (B) amostra após a homogenização e centrigugação..........

Figura 8. Grupo I - Aspectos microscópicos da reação do tecido conjuntivo subcutâneo de camundongos frente ao implante. (A) Corte histológico corado em $\mathrm{HE}$, objetiva de 4,2X; (B) área destacada da figura (A) objetiva de 20X.

Figura 9. Grupo II - Aspectos microscópicos da reação do tecido conjuntivo subcutâneo de camundongos frente ao implante. (A) Corte histológico corado em $\mathrm{HE}$, objetiva de 4,2X; (B) área destacada da figura (A) com objetiva de 20X.... 
Figura 10. Grupo III - Aspectos microscópicos da reação do tecido conjuntivo subcutâneo de camundongos frente ao implante. (A) Corte histológico corado em $\mathrm{HE}$, objetiva de 4,2X; (B) área destacada da figura $(A)$ com objetiva de 20X................................................

Figura 11. Grupo IV - Aspectos microscópicos da reação do tecido conjuntivo subcutâneo de camundongos frente ao implante. (A) Corte histológico corado em HE, objetiva de 4,2X; (B) área destacada da figura (A) com objetiva de $20 \mathrm{X}$.

Figura 12. Grupo $V$ - Aspectos microscópicos da reação do tecido conjuntivo subcutâneo de camundongos frente ao implante. (A) Corte histológico corado em $\mathrm{HE}$, objetiva de 4,2X; (B) área destacada da figura (A) com objetiva de 20X.

Figura 13. Grupo VI - Aspectos microscópicos da reação do tecido conjuntivo subcutâneo de camundongos frente ao implante. (A) Corte histológico corado em $\mathrm{HE}$, objetiva de 4,2X, (B) área destacada da figura (A) com objetiva de 20X.

Figura 14. Grupo VII - Aspectos microscópicos da reação do tecido conjuntivo subcutâneo de camundongos frente ao implante. (A) Corte histológico corado em $\mathrm{HE}$, objetiva de 4,2X; (B) área destacada da figura (A) com objetiva de 20X.

Figura 15. Grupo VIII - Aspectos microscópicos da reação do tecido conjuntivo subcutâneo de camundongos frente ao implante. (A) Corte histológico corado em HE, objetiva de 4,2X; (B) área destacada da figura (A) com objetiva de 20X

81

Figura 16. Grupo IX - Aspectos microscópicos da reação do tecido conjuntivo subcutâneo de camundongos frente ao implante. (A) Corte histológico corado em $\mathrm{HE}$, objetiva de 4,2X; (B) área destacada da figura (A) com objetiva de $20 \mathrm{X}$

Figura 17. Grupo $X$ - Aspectos microscópicos da reação do tecido conjuntivo subcutâneo de camundongos frente ao implante. (A) Corte histológico corado em $\mathrm{HE}$, objetiva de 4,2X; (B) área destacada da figura (A) com objetiva de 20X.

Figura 18. Grupo XI - Aspectos microscópicos da reação do tecido conjuntivo subcutâneo de camundongos frente ao implante. (A) Corte histológico corado em $\mathrm{HE}$, objetiva de 4,2X; (B) área destacada da figura (A) com objetiva de 20X 
Figura 19. Grupo XII - Aspectos microscópicos da reação do tecido conjuntivo subcutâneo de camundongos frente ao implante. (A) Corte histológico corado em $\mathrm{HE}$, objetiva de 4,2X; (B) área destacada da figura (A) com objetiva de 20X

Figura 20. Grupo XIII - Aspectos microscópicos da reação do tecido conjuntivo subcutâneo de camundongos frente ao implante. (A) Corte histológico corado em $\mathrm{HE}$, objetiva de 4,2X; (B) área destacada da figura (A) com objetiva de $20 \mathrm{X}$

Figura 21. Grupo XIV - Aspectos microscópicos da reação do tecido conjuntivo subcutâneo de camundongos frente ao implante. (A) Corte histológico corado em $\mathrm{HE}$, objetiva de 4,2X; (B) área destacada da figura (A) com objetiva de 20X.

Figura 22. Grupo XV - Aspectos microscópicos da reação do tecido conjuntivo subcutâneo de camundongos frente ao implante. (A) Corte histológico corado em $\mathrm{HE}$, objetiva de 4,2X; (B) área destacada da figura (A) com objetiva de $20 \mathrm{X}$

Figura 23. Grupo XVI - Aspectos microscópicos da reação do tecido conjuntivo subcutâneo de camundongos frente ao implante. (A) Corte histológico corado em $\mathrm{HE}$, objetiva de 4,2X; (B) área destacada da figura (A) com objetiva de $20 \mathrm{X}$

Figura 24. Grupo XVII - Aspectos microscópicos da reação do tecido conjuntivo subcutâneo de camundongos frente ao implante. (A) Corte histológico corado em $\mathrm{HE}$, objetiva de 4,2X; (B) área destacada da figura (A) com objetiva de $20 \mathrm{X}$

Figura 25. Grupo XVIII - Aspectos microscópicos da reação do tecido conjuntivo subcutâneo de camundongos frente ao implante. (A) Corte histológico corado em $\mathrm{HE}$, objetiva de 4,2X; (B) área destacada da figura (A) com objetiva de $20 \mathrm{X}$

Figura 26. Grupo XIX - Aspectos microscópicos da reação do tecido conjuntivo subcutâneo de camundongos frente ao implante. (A) Corte histológico corado em $\mathrm{HE}$, objetiva de 4,2X; (B) área destacada da figura (A) com objetiva de 20X.

Figura 27. Grupo XX - Aspectos microscópicos da reação do tecido conjuntivo subcutâneo de camundongos frente ao implante. (A) Corte histológico corado em $\mathrm{HE}$, objetiva de 4,2X; (B) área destacada da figura (A) com objetiva de $20 \mathrm{X}$ 
Figura 28. Grupo XXI - Aspectos microscópicos da reação do tecido conjuntivo subcutâneo de camundongos frente ao implante. (A) Corte histológico corado em $\mathrm{HE}$, objetiva de 4,2X; (B) área destacada da figura $(A)$ com objetiva de 20X...............................................

Figura 29. Grupo XXII - Aspectos microscópicos da reação do tecido conjuntivo subcutâneo de camundongos frente ao implante. (A) Corte histológico corado em $\mathrm{HE}$, objetiva de 4,2X; (B) área destacada da figura (A) com objetiva de 20X.

Figura 30. Grupo XXIII - Aspectos microscópicos da reação do tecido conjuntivo subcutâneo de camundongos frente ao implante. (A) Corte histológico corado em $\mathrm{HE}$, objetiva de 4,2X; (B) área destacada da figura (A) com objetiva de 20X.

Figura 31. Grupo XIV - Aspectos microscópicos da reação do tecido conjuntivo subcutâneo de camundongos frente ao implante. (A) Corte histológico corado em $\mathrm{HE}$, objetiva de 4,2X; (B) área destacada da figura (A) com objetiva de $20 \mathrm{X}$....

Figura 32. Média e desvio padrão da citocina IL-2, nos diferentes grupos avaliados.

Figura 33. Média e desvio padrão da citocina IL-6, nos diferentes grupos avaliados.

Figura 34. Média e desvio padrão da citocina TNF-a, nos diferentes grupos avaliados.

Figura 35. Média e desvio padrão da citocina IFN- $\gamma$, nos diferentes grupos avaliados.

Figura 36. Média e desvio padrão da citocina IL-4, nos diferentes grupos avaliados.

Figura 37. Média e desvio padrão da citocina IL-10, nos diferentes grupos avaliados.

Figura 38. Média e desvio padrão da citocina IL-17, nos diferentes grupos avaliados. 


\section{RESUMO}

\section{ABSTRACT}

1. INTRODUÇÃO.

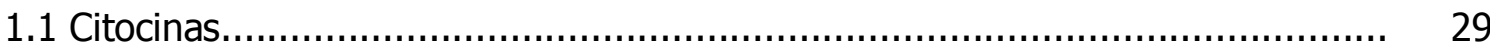

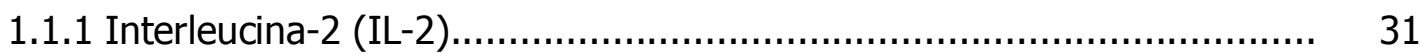

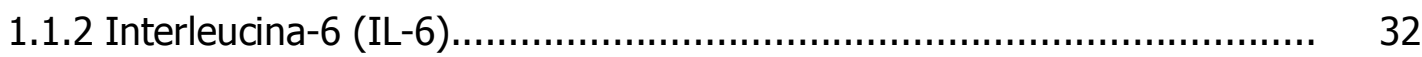

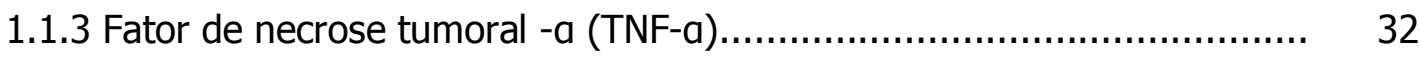

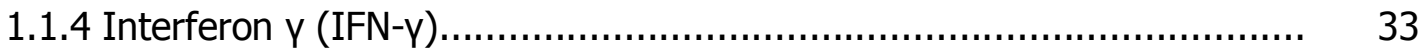

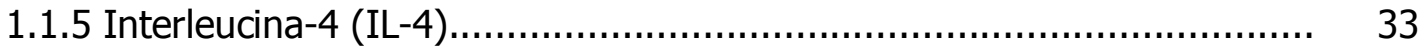

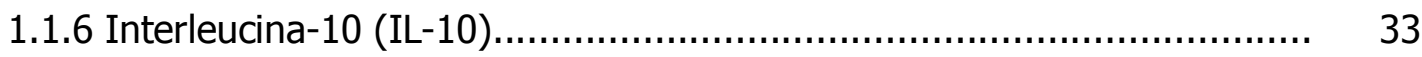

1.1.7 Interleucina-17A (IL-17A)...................................................... 34

2. PROPOSIÇÃO................................................................................... 35

3. MATERIAL E MÉTODOS.................................................................. 39

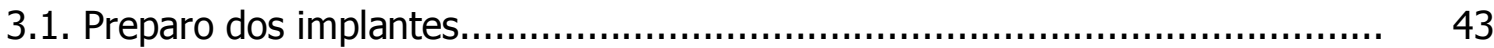

3.2. Preparo dos Aplicadores................................................................. 47

3.3. Preparo dos implantes para instalação..................................................... 49

3.4. Procedimento Operatório........................................................................ 51

3.5. Processamento Histológico e análise microscópica descritiva......................... 57

3.6. Processamento para a dosagem de citocinas............................................ 59

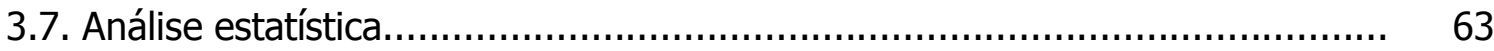

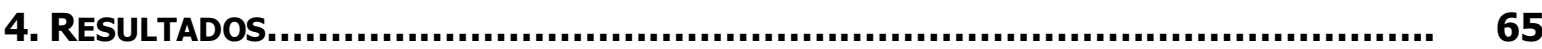

4.1. Análise Microscópica descritiva.............................................................. 67

4.2 Variação da produção de citocinas frente aos diferentes cimentos nos diferentes tempos experimentais - Teste CBA................................................ 101

5. DISCUSSÃO

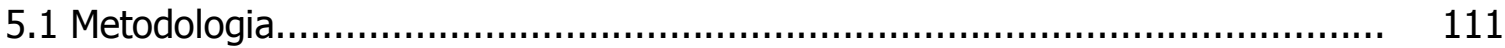

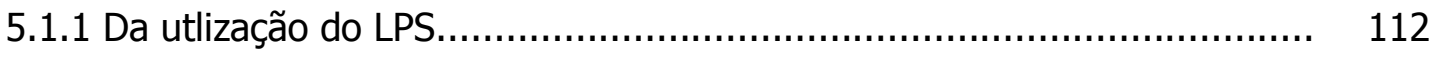

5.1.2 Da dosagem das citocinas.......................................................... 113

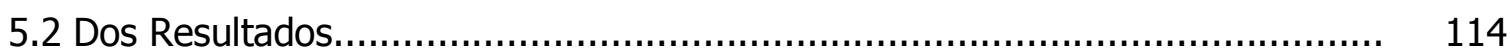

5.2.1 Grupos com a presença do LPS.................................................. 114

5.2.2 Grupos sem a presença do LPS................................................. 115

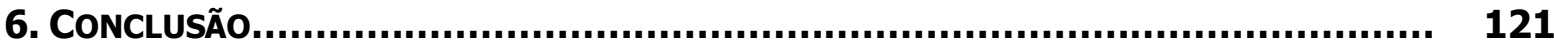

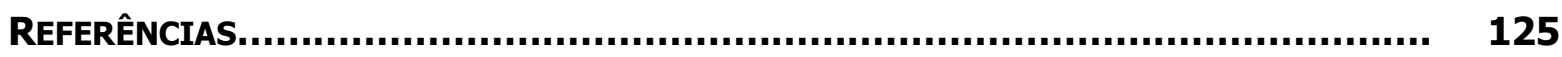

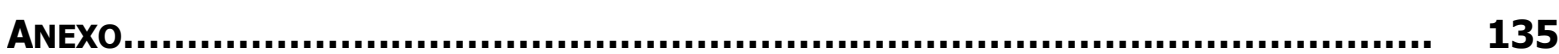





\section{RESUMO}

\section{Pereira, LB. Avaliação do Perfil de Citocinas no Tecido Subcutâneo de}

Camundongos na Presença de Cimento Endodôntico [tese]. Ribeirão Preto: Faculdade de odontologia de Ribeirão Preto - Universidade de São Paulo; 2013

Avaliou-se a capacidade dos cimentos endodônticos: Sealapex ${ }^{\circledR}$, Activ-GP ${ }^{\circledR}$ e AH-Plus ${ }^{\circledR}$ de alterarem o perfil das citocinas nas respostas Th1, Th2 e Th17, após a implantação destes em subcutâneo de camundongos. A quantificação das citocinas IL-2, IL-6, TNF-a, IFN- $ү$, IL4, IL-10 e IL-17 foi realizada in vivo, no tecido reacional circundante aos implantes, os quais foram confeccionados a partir de sondas nasogástricas estéreis e apirogênicas de cloreto de polivinila preenchidas com os cimentos, tendo um grupo controle com sondas vazias. Utilizou-se camundongos isogênicos da linhagem C57BL/6 machos de 6/8 semanas de vida sendo que cada um recebeu 2 implantes na região dorsal (lado direito e esquerdo). Após os períodos experimentais de 7, 21 e 63 dias, com os camundongos anestesiados, os implantes foram removidos juntamente com o tecido circundante, e os animais sacrificados em seguida por deslocamento cervical. As amostras de cada grupo foram divididas sendo: duas, contendo implante/tecido, processadas histotecnicamente e as demais com apenas tecido (sem implante) foram homogeneizadas e centrifugadas com solução formada por tampão RIPA e inibidor de protease. O sobrenadante, fruto deste processo, foi coletado e a dosagem das citocinas realizada através do kit CBA mouse-Th1/Th2/Th17 Cytokine Kit (BD Cytometric Bead Array, San Jose, CA, USA) em análise por citometria de fluxo. Os parâmetros avaliados foram a concentração da citocina em função do cimento testado em cada período experimental. Submeteu-se os resultados à análise estatística por meio do teste $t$ com a correção de Welch's. Para todos os testes o nível de significância foi de 5\%. Com relação à IL-2 houve diferenças estatísticas significantes entre os grupos Activ-GP ${ }^{\circledR}$ e AH-Plus ${ }^{\circledR}$ $(p=0,0391)$. No período de 21 dias foram detectadas diferenças entre o grupo controle e AHPlus $^{\circledR}(p=0,0402)$ e entre o grupo Sealapex ${ }^{\circledR}$ e AH-Plus ${ }^{\circledR}(p=0,0244)$. O AH-Plus ${ }^{\circledR}$ induziou um maior aumento na IL-6, aos 7 dias em relação ao Activ-GP ${ }^{\circledR}(p=0,0286)$ e aos 21 dias entre o grupo controle $(p=0.0402)$ e $\operatorname{Activ-GP}^{\circledR}(p=0.0244)$. Os níveis de TNF-a foram estatisticamente superiores após 7 dias quando comparou-se o grupo AH-Plus ${ }^{\circledR}$ com os demais. Observou-se que no grupo controle aos 7 e 21 dias ocorreram diferenças estatísticas em relação ao Sealapex ${ }^{\circledR}$ e AH-Plus ${ }^{\circledR}$ respectivamente quando avaliadas as concentrações de IFN- $\gamma$. Houve também diferenças estatísticas entre o grupo controle e Sealapex ${ }^{\circledR}(p=0,0158)$ no período de 7 dias para a citocina IL-4. Os valores de IL-10 foram estatisticamente 
superiores para o grupo controle em relação ao Activ-GP ${ }^{\circledR}$ no período de 21 dias $(p=0,0471)$. Com relação a IL-17 no período de 21 dias, observou-se os maiores valores para o grupo controle, seguido pelo Sealapex ${ }^{\circledR}$, Activ-GP ${ }^{\circledR}$ e AH-Plus ${ }^{\circledR}$. Foram detectadas diferenças entre os grupos controle e AH-Plus ${ }^{\circledR}(p=0,0121)$, controle e Activ-GP ${ }^{\circledR}(p=0,0262)$ e entre Sealapex ${ }^{\circledR}$ e Activ GP $^{\circledR}(p=0,0314)$. Baseado nesses resultados pode-se concluir que: os cimentos endodônticos são capazes de modular as respostas Th1, Th2 e Th17 através da inibição ou estimulação da liberação das citocinas testadas. O cimento AH-Plus ${ }^{\circledR}$ promoveu as maiores diferenças no perfil de resposta Th1.

Palavras-chave: 1. Endodontia, 2. Cimentos endodônticos, 3. Citocinas, 4. Células Th1, 5.Células Th2, 6. Células Th17, 7. Tecido Subcutâneo, 8. Citometria de fluxo 


\section{Abstract}

\section{Pereira, LB. Evaluation of Cytokine Profile in Subcutaneous Tissue of Mice in the}

Presence of Endodontic Cement [thesis]. Ribeirao Preto: Faculty of Dentistry of Ribeirão Preto - University of São Paulo, 2013

It was evaluated the capacity of the following endodontic sealers: Sealapex ${ }^{\circledR}$, Activ-GP ${ }^{\circledR}$ and AH-Plus $^{\circledR}$ to modify the cytokine profile in Th1, Th2 and Th17 responses, after their implantation in the subcutaneous tissue of mice. Quantification of IL-2, IL-6, TNF- $a$, IFN- $y$, IL-4, IL-10 and IL-17 was performed in vivo, in the reactional tissue surrounding the implants, which were made from sterile nasogastric probes and apyrogenic of polyvinyl chloride filled with sealer, and a control group of empty probes. It was used isogenic mice of C57BL/6 lineage, 6/8 weeks old males, each of which received two implants in the dorsal region (left and right). After the experimental time of 7, 21 and 63 days, the mice were anesthetized and the implants were removed along with the surrounding tissue, the animals were then sacrificed by cervical dislocation. Samples from each group were divided as follows: two containing implant / tissue processed histologically and with only the remaining tissue (without implant) were mixed and centrifuged with a solution formed by RIPA buffer and protease inhibitors. The supernatant result of this process was collected and cytokine dosage accomplished by mouse-Th1/Th2/Th17 Cytokine CBA Kit Kit (BD cytometric Bead Array, San Jose, CA, USA) for flow cytometry analysis. The evaluated parameters were the cytokine concentration in function of sealer tested in each trial. The results were submitted to statistical analysis using the $t$ test with Welch's correction. For all tests the significance level was $5 \%$. With respect to IL-2 there were significant statistical differences between groups-Activ $\mathrm{GP}^{\circledR}$ and $\mathrm{AH}$-Plus ${ }^{\circledR}(\mathrm{p}=0.0391)$. In the period of 21 days differences were found between the control group and $\mathrm{AH}-\mathrm{Plus}^{\circledR}(\mathrm{p}=0.0402)$ and between the group Sealapex ${ }^{\circledR}$ and AH-Plus ${ }^{\circledR}(p=0.0244)$. The AH-Plus ${ }^{\circledR}$ induced a greater increase in IL-6, at 7 days compared to Activ-GP ${ }^{\circledR}(p=0.0286)$ and at 21 days between the control group $(p=0.0402)$ and Activ$\mathrm{GP}^{\circledR}(\mathrm{p}=0.0244)$. The levels of TNF-a were significantly higher after 7 days when the AHPlus $^{\circledR}$ group was compared with others. It was observed that in the control group at 7 and 21 days there were statistical differences in relation to Sealapex and AH-Plus ${ }^{\circledR}$ respectively when evaluated concentrations of IFN-y. There were also significant differences between the control group and Sealapex ${ }^{\circledR}(p=0.0158)$ within 7 days for the cytokine IL-4. The amounts of $\mathrm{IL}-10$ were statistically higher in the control group compared to the Activ $\mathrm{GP}^{\circledR}$ in a period of 
21 days $(p=0.0471)$. With respect to IL-17 in a period of 21 days, it was observed the highest values for the control group, followed by Sealapex ${ }^{\circledR}$, Activ-GP ${ }^{\circledR}$ and AH-Plus ${ }^{\circledR}$. Differences were found between the control groups and AH-Plus $(p=0.0121)$, control and Activ-GP ${ }^{\circledR}(p=0.0262)$ and between Sealapex ${ }^{\circledR}$ and Activ-GP ${ }^{\circledR}(p=0.0314)$. Based on the presented results theendodontic sealers are able to promote changes in the response cytokine profile Th1, Th2 and Th17; Sealer AH-Plus ${ }^{\circledR}$ produced the greatest changes, in the Th1 response profile.

Keywords: 1 .Endodontics, 2. Sealers, 3. Cytokines, 4. Th1 cells, 5. Th2 cells, 6 . Th17 cells, 7. Subcutaneous Tissue, 8. Flow cytometry 


$$
\text { Introdução }
$$





\section{INTRODUÇÃO}

O tecido pulpar é circunscrito por uma parede rígida e inextensível de dentina que, em condições normais, não possui uma microbiota residente. No entanto, os microrganismos da cavidade oral podem infectar este local por diferentes vias: através da exposição dos túbulos dentinários causada pela cárie, por restaurações mal-adaptadas, procedimentos cirúrgicos, traumas que levam a trincas, fraturas e através da circulação sanguínea (via anacorética) (Nair, 1997; 1998). No momento em que os patógenos conseguem se instalar e agredir esse tecido, alterações imuno-inflamatórias ocorrerão, causando a formação de um edema intrapulpar e a deposição de um tecido mineralizado na tentativa de isolar o agente agressor (Paula-Silva, Da Silva et al., 2010).

A formação do edema irá comprimir os vasos sanguíneos da polpa dentária, dificultando a circulação e reduzindo o aporte de oxigênio. Os processos metabólicos pulpares cessam juntamente com a perda da sua estrutura, culminando em necrose. 0 tecido pulpar necrosado proverá, então, livre acesso aos microrganismos da cavidade oral, oferecendo as condições ideais para a formação de biofilmes e colônias bacterianas dentro do canal radicular. Uma vez instalado o biofilme, haverá a produção das endotoxinas e derivados da desintegração pulpar que podem atravessar o forame apical, passando a induzir alterações nos tecidos periodontais adjacentes. Tais alterações ocorrerão, inicialmente, através da ativação dos macrófagos que liberam vários mediadores entre eles o fator de necrose tumoral alfa (TNF-a) e outras citocinas (Nair, Meghi et al., 1996; Nair, 1997; Marton e Kiss, 2000). É importante ressaltar que a presença desses microrganismos na lesão periapical é uma exceção, e não uma regra (Block, Bushell et al., 1976). Sendo assim, o desenvolvimento das alterações perirradiculares consequência do efeito de uma infecção instalada no sistema de canais (Marton e Kiss, 2000; Fouad e Acosta, 2001).

As técnicas de microbiologia utilizadas para cultura e identificação de microrganismos, têm demonstrado que os canais radiculares de dentes com necrose pulpar e lesão periapical crônica tem o predomínio de bactérias anaeróbias, especialmente as Gramnegativas (Silva, Nelson-Filho et al., 2002). Estes microrganismos apresentam diferentes fatores de virulência e geram produtos e subprodutos que são tóxicos para os tecidos apicais e periapicais, além de liberarem endotoxinas durante a sua multiplicação e/ou morte (Rocha, Rossi et al., 2008).

Endotoxina foi o termo utilizado por Richard Pfeitter (1992) para designar uma macromolécula altamente pirogênica, mais tarde identificada como um lipopolissacarídeo (LPS), uma parte integrante da camada externa da parede celular de bactérias Gram- 
negativas. O LPS tem papel importante no surgimento e evolução das lesões periapicais uma vez que ele é um desafio ao sistema imunológico, produzindo uma variedade de efeitos biológicos. Dentre eles há a ativação do fator Hageman (fator XII da coagulação), o qual pode causar choque séptico com efeito letal em animais, além de induzir febre, ativar o sistema complemento, atuar nas reações da resposta inflamatória (aumento da permeabilidade vascular, da quimiotaxia de neutrófilos e macrófagos, da liberação de lisozimas e linfocinas e da ativação do ciclo metabólico do ácido araquidônico). Em canais radiculares infectados, as endotoxinas podem contribuir para um aumento da liberação de substâncias vasoativas e neurotransmissores na região das terminações nervosas nos tecidos periapical, causando dor (Leonardo, Silva et al., 2004). Sendo assim, as lesões periapicais são basicamente o mesmo que é visto em outros tecidos de granulação que se desenvolvem a partir do tecido conjuntivo ao redor da área danificada. Uma característica comum às lesões periapicais, é a exsudação persistente de grande número de células imunológicas como os leucócitos polimorfonucleares, mononucleares e células do sangue (Kettering e Torabinejad, 1993; De Rossi, Rocha et al., 2008).

O tratamento endodôntico consiste em variadas manobras técnicas que visam restabelecer a normalidade dos tecidos dentais, ou pelo menos manter a estrutura dentária em seu alvéolo sem presença de inflamação ou infecção. Este procedimento baseia-se em remover todo o tecido, vivo ou não, da câmara pulpar e do sistema de canais radiculares presente nas raízes selando-os em seguida. Portanto, a obturação dos canais radiculares bem como o preparo biomecânico são etapas do tratamento endodôntico visando o selamento hermético do canal radicular, impedindo a infiltração e inibindo o crescimento bacteriano (Nassri, Lia et al., 2003; Valera, Leonardo et al., 2004; Gomes-Filho, Bernabe et al., 2008). Assim o sucesso desta terapia está diretamente associado a uma resposta imunológica bem sucedida e ao cumprimento de todas as fases operatórias necessárias e interdependentes.

Uma ênfase maior tem sido dada à resposta biológica pós-tratamento, observando se houve reparação a partir de um selamento apical efetivo e biológico por meio de tecido mineralizado ou fibroso (Holland e De Souza, 1985). Fatores inerentes à etapa da obturação, como a natureza do material obturador e sua compatibilidade biológica, tem sua importância confirmada nas pesquisas que revelam ser a maioria dos cimentos obturadores irritantes aos tecidos apicais e periapicais (Leonardo, 1991).

Outro aspecto que vem sendo estudado é a capacidade dos cimentos endodônticos interferirem na resposta imune (Bernath e Szabo, 2003; De Oliveira Mendes, Ribeiro Sobrinho et al., 2003; Gomes-Filho, Watanabe et al., 2009; Gomes-Filho, Gomes et al., 
2011). Associando-se a inflamação já existente fruto do processo patológico à possível irritação ocasionada pelos materiais obturadores, a resposta inflamatória poderá ser persistente mesmo após a obturação (Perassi, Filho et al., 2004). Por conseguinte, na presença de uma resposta mal sucedida, corre-se o risco de haver processos inflamatórios mais vigorosos, associados a fenômenos vasculares e exudativos que prejudicarão fisiológica e funcionalmente, o hospedeiro. Em casos cuja inflamação se estabeleça por longo período, a partir da resistência e persistência de fatores agressores, a intensidade e o aspecto do processo, serão modificados, levando a cronificação do processo (Baldwin e Hunt, 2008). Desta forma ao invés de cumprir seu papel de defesa e auxílio na reparação, a resposta inflamatória persistente após a obturação e poderá inibir o processo de reparo (Grossman, 1976). Nesse cenário, haverá um grande acúmulo celular e de mediadores inflamatórios secretados, relacionados à resposta imunológica denominados citocinas (Baldwin e Hunt, 2008). Portanto, as células do sistema imunológico são capazes de produzir e liberar citocinas que direcionarão a resposta inflamatória, além de, em alguns casos, promover reações lesivas agudas e crônicas nos tecidos periapicais (Coico, 2010).

\subsection{Citocinas}

Foi em 1974, que Stanley Cohen introduziu pela primeira vez o termo citocina, do grego cito que significa "célula" e cininas "hormônios" (Tayal e Kalra, 2008). Este termo abrangente engloba uma variedade de citocinas e seus nomes são registrados, quase sempre considerando o local de sua identificação, a origem, ou sua forma molecular. Dessa maneira temos as interleucinas (IL), linfocinas, monocinas, fatores estimuladores de colônias (CSFs), interférons (IFN), fator de necrose tumoral (TNF) e quimiocinas (Paul, 1999; Consolaro, 2009).

As citocinas tem a forma de pequenas seqüências de aminoácidos, ou peptídeos capazes de interagir-se com receptores específicos das membranas celulares, induzindo fenômenos diferentes e antagônicos em células morfológica e funcionalmente diferentes. Assim, atuam como mensageiros químicos no sistema imunológico, comunicando-se com células em outros sistemas. A interpretação da mensagem depende da via metabólica a ser ativada naquele tipo de célula (Consolaro, 2009), sendo localmente de forma autócrina (agindo na mesma célula que a secreta), parácrina (em células diferentes) ou ainda atuar sistemicamente (endócrina) (Tayal e Kalra, 2008; Coico, 2010). Entre as funções das citocinas estão: mediar e regular respostas imunitárias, inflamação, hematopoiese e controle da proliferação e diferenciação celular. 
As citocinas possuem três propriedades fundamentais:

1- Pleiotropia, isto é, elas podem atuar de maneira diferente nos diferentes tipos celulares;

2- Redundância, ou seja, funções similares podem ser estimuladas por diferentes citocinas;

3- Multifuncionalidade, refererindo-se ao fato de que uma mesma citocina pode regular diferentes funções imunitárias (Tayal e Kalra, 2008).

O recrutamento celular durante o processo inflamatório e essencial para controlar a infecção periapical. Isto é resultado da expressão de moléculas de adesão na superfície vascular de celular endoteliais, induzidas por citocinas IL-1a, IL-1ß e TNF-a e quimiocinas. A produção das quimiocinas nestas lesões pode ser iniciada por elas próprias, por citocinas e/ou produtos bacterianos (Silva, Garlet et al., 2007).

A reabsorção óssea encontrada nas lesões periapicais induzidas em animais (camundongos e ratos) ocorre a partir do desequilíbrio entre a atividade de osteoclastos e osteoblastos. Entre a primeira e segunda semanas de desenvolvimento das lesões periapicais (fase aguda) predomina-se IL-1a, IL-1ß e TNF-a com intensa reabsorção óssea no local. Nas semanas seguintes ocorre a mudança no perfil das citocinas para IL-4, IL-10 e IL-13, relacionadas com a fase crônica do processo (Stashenko, Dewhirst et al., 1987; Stashenko, Teles et al., 1998).

A presença de células apresentadoras de antígenos (APCs) em especial as dendríticas (DCs) são fundamentais para a ativação dos linfócitos T-helper em linfócitos Th1, Th2 e Th17. Acredita-se que a resposta imune Th1 é mediada pelo IFN- $\gamma$, em conjunto com outras citocinas pró-inflmatórias como IL-1, IL-6 e TNF-a, estando todas envolvidas na progressão e reabsorção óssea das lesões periapicais. Em contrapartida, os mecanismos imunosupressores relacionados aos processos de cura e restrição dessas lesões, são mediados por citocinas envolvidas na resposta Th2 (IL-4, IL-5 e IL-10) (Kawashima e Stashenko, 1999; Colic, Gazivoda et al., 2009).

Embora as citocinas possam ser produzidas por muitas populações de células, os produtores predominantes são as células T-helper, macrófagos e células dendríticas (Rossi e Zlotnik, 2000). As citocinas tem um papel fundamental na determinação do perfil da resposta imune através da diferenciação de células T CD4+ em linfócitos T-helper tipo 1(Th1) ou Thelper tipo 2(Th2). A presença de IL-12 e IFN-y estimula a diferenciação das células T CD4+ em linfócitos Th1 determinando um perfil pró-inflamatório por outro lado a presença de IL-4 vai estimular a diferenciação em linfócitos Th2 originando um perfil anti-inflamatório (Rossi e Zlotnik, 2000; Dong, 2006). 
A regulação do processo de diferenciação das células T ocorre a partir da utilização de diferentes mecanismos moleculares utilizados pelas citocinas. As citocinas produzidas pelas células Th1 inibem a produção das células Th2 e vice-versa em um mecanismo de regulação cruzada. Este tipo de regulação é responsável pela relação inversa entre a produção de anticorpos e a imunidade celular (Rossi e Zlotnik, 2000; Ansel, Lee et al., 2003; De Rossi, Rocha et al., 2008; Colic, Gazivoda et al., 2009).

Além das respostas Th1 e Th2 já estabelecidas estudos indicam também a participação de outros tipos celulares na patogênese de lesões periapicais, de modo que a presença de células $T$ regulatórias (Tregs), bem como das células Th17 recentemente descritas tem sido investigadas (Colic, Vasilijic et al., 2007; Colic, Gazivoda et al., 2009). As células Th17 são uma sub-população de células T CD4+ que secretam IL-17 sendo o seu principal produto por isso recebem esse nome. Essa citocina pró-inflamatória apresenta potentes efeitos em diversos tipos celulares da imunidade inata, particularmente granulócitos, atuando com um elemento de ligação entre o sistema imune inato e adiquirido (Gaffen, Kramer et al., 2006). Segundo Dong (2006), a resposta imune adaptativa mediada pelas células Th1 e Th2 deve ser repensada pois as células Th17 tem um papel importante na regulação da inflamação dos tecidos e não depende das citocinas que regulam a resposta Th1 e Th2. Alguns estudos sugerem que a família das IL-17 coordena a inflamação local, pela liberação de citocinas pró-inflamatórias e recrutamento de neutrófilos (Kolls e Linden, 2004; Colic, Vasilijic et al., 2007; Colic, Gazivoda et al., 2009; Wu, Zhu et al., 2013).

\subsubsection{Interleucina-2 (IL-2)}

Por possuir a capacidade de estimular a proliferação de linfócitos T estimulados por antígenos, a interleucina-2 (IL-2) é também chamada de fator de crescimento, sobrevivência e diferenciação dessas células. A IL-2 é sintetizada principalmente por linfócitos T CD4+ e possui ações autócrinas e parácrinas. A expressão de receptores funcionais para IL-2 é principalmente induzida quando da ativação de linfócitos $T$ virgens e efetores. Contudo linfócitos T reguladores sempre expressam receptores para IL-2. Entre as principais funções biológicas da IL-2 estão: sobrevivência e provavelmente manutenção da função de células T regulatórias suprimindo respostas contra antígenos próprios e alguns antígenos exógenos; sobrevivência, proliferação e diferenciação de linfócitos T ativados por antígeno; proliferação e diferenciação de células exterminadoras naturais (NK); em linfócitos B a IL-2 parece atuar como estímulo para síntese de anticorpos (Commins, Borish et al., 2010). 


\subsubsection{Interleucina-6 (IL-6)}

A interleucina-6 está diretamente relacionada com as respostas imunológicas naturais estimuladas por vírus e patógenos microbianos. Ela é produzida por diversos tipos celulares sendo os principais os fagócitos como os macrófagos e neutrófilos. Outra importante função da IL-6 é a síntese de proteínas da fase aguda, ativação de células T, produção de IL-2 e crescimento celular de progenitores hematopoiéticos (Coico, 2010).

\subsubsection{Fator de necrose tumoral -a (TNF-a)}

O TNF é um dos principais mediadores da fase aguda da resposta inflamatória a bactérias gram-negativas e outros microrganismos infecciosos. Contudo, o TNF também parece ser o grande responsável por várias das complicações sistêmicas comumente presentes nos casos de infecções graves. A nomenclatura empregada ao TNF foi embasada na observação original de uma substância presente no PBS que causava necrose de alguns tipos de tumores. O TNF é, com freqüência, chamado de TNF-a para diferenciá-lo do TNF- $\beta$, o qual é secretado principalmente por linfócitos e por isso conhecido como linfotoxina (LT) (Abbas, 2008; Coico, 2010).

Vários tipos celulares têm a capacidade de sintetizar o TNF (ex: linfócitos T estimulados, células NK, mastócitos e fagócitos). Contudo, os fagócitos mononucleares ativados são a principal fonte de TNF. Um dos estímulos mais potentes para levar a liberação de TNF por macrófagos, por exemplo, é a ativação de um tipo de receptor do tipo toll 4 (TLR4) pela molécula de lipopolissacarídeo (LPS) entre outros produtos presentes em microrganismos (Hong, Lin et al., 2004; Coico, 2010).

Entre as funções biológicas do TNF estão à estimulação do recrutamento de neutrófilos e monócitos para locais de infecção e ativar essas células para erradicar microrganismos. Além dos efeitos celulares, podem existir efeitos sistêmicos dependentes das concentrações plasmáticas de TNF. Os efeitos sistêmicos de elevadas concentrações de TNF são geralmente os principais causadores das complicações observadas na síndrome da reação inflamatória sistêmica e na síndrome do choque séptico, que pode ser induzido em animais de laboratório pela injeção de LPS ou TNF (Abbas, 2008). Avaliando a liberação de TNF-a em cultura de células de macrófagos do peritônio de camundongos associada aos cimentos endodônticos Sealapex ${ }^{\circledR}$ ou Endomethasone foi constatada a capacidade destes materiais em promover o aumento da liberação de TNF-a (Perassi, Filho et al., 2004). 


\subsubsection{Interferon Y (IFN-Y)}

Esta citocina é sintetizada por células NK, linfócitos Th1, sendo a citocina que caracteriza a respostas mediadas por linfócitos Th1. Na imunidade natural o IFN- $\gamma$ é secretado por células NK em resposta à IL-12 ou a ligantes ativadores presentes em células infectadas ou que estão em estado de estresse. As funções biológicas do IFN- $\gamma$, são de extrema importância para imunidade mediada por células contra microrganismos intracelulares. Entre essas ações estão à ativação das capacidades microbicidas de macrófagos (ex: transcrição de genes que codificam enzimas produtoras de espécies reativas de oxigênio e óxido nítrico) principalmente pela liberação de IFN-ץ por linfócitos Th1. Juntamente a diferenciação de células T CD4+ em células Th1 é dependente de IFN- $\gamma$, o que leva a inibição da proliferação de células Th2 (Commins, Borish et al., 2010).

\subsubsection{Interleucina-4 (IL-4)}

A IL-4 apresenta papel fundamental na síntese de isotipos de IgE e IgG no desenvolvimento de linfócitos Th2, sendo a principal citocina indutora e efetora destas células. Suas ações biológicas envolvem respostas imunes contra helmintos e artrópodes, a partir da participação de linfócitos Th2, IgE e da ação de eosinófilos. Além disso, a IL-4 funciona como fator de crescimento autócrino para linfócitos Th2 inibindo ao mesmo tempo o desenvolvimento de células Th1 e Th17, ações estas contrárias às do IFN-Y. Adicionalmente, a IL-4, em conjunto com IL-13, promove ativação alternativa de macrófagos (Abbas, 2008).

\subsubsection{Interleucina-10 (IL-10)}

A interleucina-10 (IL-10) é uma citocina regulatória, devido a sua capacidade de inibir macrófagos, células Th1 e células dendríticas ativadas, possuindo importante papel no controle de respostas envolvendo imunidade natural mediada por células. As principais fontes de IL-10 são macrófagos ativados e linfócitos Th2. Em macrófagos, a IL-10 tem a importante tarefa de fazer com que estas células retornem ao estado de pré-ativação nos momentos em que a infecção microbiana já foi erradicada. Um dos mecanismos envolvidos na modulação da atividade dos macrófagos por parte da IL-10 envolve a inibição da produção da IL-12, a qual estimula a liberação de interferon- $\gamma$ (IFN- $\gamma$ ), que tem papel 
fundamental na ativação de respostas naturais mediadas por células. (Commins, Borish et al., 2010).

\subsubsection{Interleucina-17A (IL-17A)}

As células Th17 são uma sub-população de células CD4+ que secretam IL-23 e IL17 sendo o seu principal produto, por isso recebem esse nome. Essa citocina próinflamatória apresenta potentes efeitos em diversos tipos celulares da imunidade inata, particularmente granulócitos, atuando como um elemento de ligação entre o sistema imune inato e adiquirido (Gaffen, Kramer et al., 2006).

Esta citocina é secretada por células T ativadas e de memória e atua sobre células epiteliais, endoteliais, fibroblastos e macrófagos para que estas estimulem a produção de outras citocinas como TNF, IL-1, IL-6 e IL-8. Desta forma seus efeitos pró-inflamatórios são mediados pelo seu receptor IL-17R expresso em diversos tipos celulares (Aggarwal e Gurney, 2002). Takahashi et al. (2005) apontam que a IL-17 estimula a resposta inflamatória, auxilia na resposta imune Th1 e estimula a osteoclastogênese. Outros estudos também associam uma maior produção de IL-17 em lesões periapicais sintomáticas (Colic, Vasilijic et al., 2007).

As células Th17 e a família das citocinas IL-17 atuam na defesa do hospedeiro contra patógenos bacterianos e alguns fungos que provavelmente não seriam eliminados pela imunidade Th1 e Th2. A IL-17 estimula a mobilização e a diferenciação de neutrófilos desempenhando um papel decisivo na autoimunidade e lesão tecidual. Foi sugerido que ela é responsável pela defesa inicial contra traumas graves que resultariam em necrose tissular ou sepse (Coico, 2010). 
Proposição 



\section{ProposiçÃo}

O objetivo deste estudo é avaliar os cimentos endodônticos: AH-Plus ${ }^{\circledR}$, Sealapex ${ }^{\circledR}$ e Activ-GP ${ }^{\circledR}$ com relação:

- A reação tecidual com e sem a estimulação por LPS bacteriano, em microscopia óptica, após implantação no tecido conjuntivo subcutâneo de camundongos.

- A produção das citocinas IL-2, IL-6, TNF-a, IFN-y, IL-4, IL-10 e IL-17A na presença ou ausência dos cimentos endodônticos. 

Material e Métodos 



\section{Material e Métodos}

O projeto de pesquisa foi submetido à apreciação do Comitê de Ética no Uso de Animais - Campus de Ribeirão Preto - Universidade de São Paulo (Protocolo $\mathrm{n}^{\circ}$ 11.1.1455.53.5) e aprovado (ANEXO A). Os critérios utilizados para a execução do experimento e para avaliação da reação tecidual seguiram as normas preconizadas pela ISO 10993-6(2007).

Foram utilizados 122 camundongos da linhagem C57BL/6 isogênicos machos, com 6 a 8 semanas de vida pesando em média $20 \mathrm{~g}$ provenientes do Biotério Central da Faculdade de Medicina de Ribeirão Preto - USP, sendo que 120 foram divididos em 24 grupos experimentais (Tabela 1). Cada animal recebeu dois implantes com os materiais testados (Tabela 2), sendo um na região dorsal direta e outro na região dorsal esquerda.

Dois animais foram destinados para a determinação do nível basal (Base line) das citocinas no tecido subcutâneo, não recebendo nenhum tipo de tratamento. A dosagem das citocinas foi realizada seguindo o mesmo protocolo utilizado para o processamento das amostras, descritos no item 3.4.6. 
Tabela 1. Determinação dos grupos, materiais empregados, número de implantes, número de animais e períodos utilizados no experimento com camundongos isogênicos C57BL/6.

\begin{tabular}{|c|c|c|c|c|}
\hline Grupos & Materiais & $\begin{array}{l}\text { Número de } \\
\text { implantes }\end{array}$ & $\begin{array}{l}\text { Número de } \\
\text { animais }\end{array}$ & Períodos \\
\hline $\mathbf{I}$ & Tubo vazio + PBS & 10 & 5 & 7 dias \\
\hline II & Tubo vazio + LPS & 10 & 5 & 7 dias \\
\hline III & Sealapex ${ }^{\circledR}+$ PBS & 10 & 5 & 7 dias \\
\hline IV & Sealapex ${ }^{\circledR}+$ LPS & 10 & 5 & 7 dias \\
\hline $\mathbf{v}$ & Activ $\mathrm{GP}^{\circledR}+$ PBS & 10 & 5 & 7 dias \\
\hline VI & Activ $\mathrm{GP}^{\circledR}+$ LPS & 10 & 5 & 7 dias \\
\hline VII & AH Plus $^{\circledR}+$ PBS & 10 & 5 & 7 dias \\
\hline VIII & AH Plus $^{\circledR}+$ LPS & 10 & 5 & 7 dias \\
\hline IX & Tubo vazio + PBS & 10 & 5 & 21 dias \\
\hline $\mathbf{x}$ & Tubo vazio + LPS & 10 & 5 & 21 dias \\
\hline $\mathbf{X I}$ & Sealapex ${ }^{\circledR}+$ PBS & 10 & 5 & 21 dias \\
\hline XII & Sealapex ${ }^{\circledR}+$ LPS & 10 & 5 & 21 dias \\
\hline XIII & Activ $\mathrm{GP}^{\circledR}+\mathrm{PBS}$ & 10 & 5 & 21 dias \\
\hline XIV & Activ $\mathrm{GP}^{\circledR}+$ LPS & 10 & 5 & 21 dias \\
\hline $\mathbf{x v}$ & AH Plus $^{\circledR}+$ PBS & 10 & 5 & 21 dias \\
\hline $\mathbf{X V I}$ & AH Plus $^{\circledR}+$ LPS & 10 & 5 & 21 dias \\
\hline XVII & Tubo vazio + PBS & 10 & 5 & 63 dias \\
\hline XVIII & Tubo vazio + LPS & 10 & 5 & 63 dias \\
\hline XIX & Sealapex ${ }^{\circledR}+$ PBS & 10 & 5 & 63 dias \\
\hline$x x$ & Sealapex ${ }^{\circledR}+$ LPS & 10 & 5 & 63 dias \\
\hline XXI & Activ $\mathrm{GP}^{\circledR}+$ PBS & 10 & 5 & 63 dias \\
\hline XXII & Activ $G P^{\circledR}+$ LPS & 10 & 5 & 63 dias \\
\hline XXIII & AH Plus $^{\circledR}+$ PBS & 10 & 5 & 63 dias \\
\hline XXIV & AH Plus $^{\circledR}+$ LPS & 10 & 5 & 63 dias \\
\hline
\end{tabular}


Tabela 2. Materiais utilizados, fabricantes e proporções.

\begin{tabular}{|c|c|c|}
\hline Material & Fabricante & Proporção \\
\hline AH-Plus ${ }^{\circledR}$ & Dentsply, Milford, DE, USA & $\begin{array}{c}\text { Partes iguais de base e } \\
\text { catalisador }\end{array}$ \\
\hline Sealapex ${ }^{\circledR}$ & $\begin{array}{c}\text { Sybron Endo, Glendora, } \mathrm{Ca} \text {, } \\
\text { USA }\end{array}$ & $\begin{array}{c}\text { Partes iguais de base e } \\
\text { catalisador }\end{array}$ \\
\hline Activ $\mathrm{GP}^{\circledR}$ & Brasseler, Savannah, GA & $\begin{array}{c}\text { Uma medida de pó para uma } \\
\text { gota de líquido }\end{array}$ \\
\hline Solução de LPS de E. Coli & $\begin{array}{c}\text { Sigma - Aldrich Sigma Chemical } \\
\text { CO. St. Louis, MO, USA }\end{array}$ & $\begin{array}{l}\text { 10mg de LPS } \\
1 \mathrm{ml} \text { de PBS }\end{array}$ \\
\hline
\end{tabular}

\subsection{Preparo dos implantes}

Para a preparação dos implantes, foram utilizadas sondas nasogástrica longas de cloreto de polivinila (PVC) transparente, flexíveis, atóxicas e apirogênicas (Mark Med ${ }^{\circledR}$ Bragança Paulista - SP - Brasil) com diametro de 4, 6 e 12 na escala French (Fr) ${ }^{1}$ cortadas com comprimento de 10mm (Figura $1 \mathrm{~A}, \mathrm{~B}, \mathrm{C}, \mathrm{D}$ ). Uma das extremidades dos tubos de calibre 4 e 6 foi fechada com o auxilio de seladora térmica. Os implantes foram confeccionados com a colocação dos dois tubos de menor calibre (4 e 6) no interior do tubo de maior calibre (Figura1 E,F). No interior da tubo de calibre 6 foi colocada uma tira de esponja de gelatina liofilizada de origem porcina esterilizada por raios gama com $1 \mathrm{~mm}$ de largura e $10 \mathrm{~mm}$ de comprimento (Hemospon Tape ${ }^{\circledR}$ - Technew, Rio de Janeiro, Brasil). O tubo de calibre menor (4) foi preenchido com os cimentos a serem testados ou permaneceu vazio nos grupos controle.

${ }^{1} \mathrm{O} \mathrm{Fr}$ (French) é a unidade de medida mais usada na área médica e indica o diâmetro externo de estruturas tubulares. Um French (Fr) corresponde a 0.33milimetros (mm). 


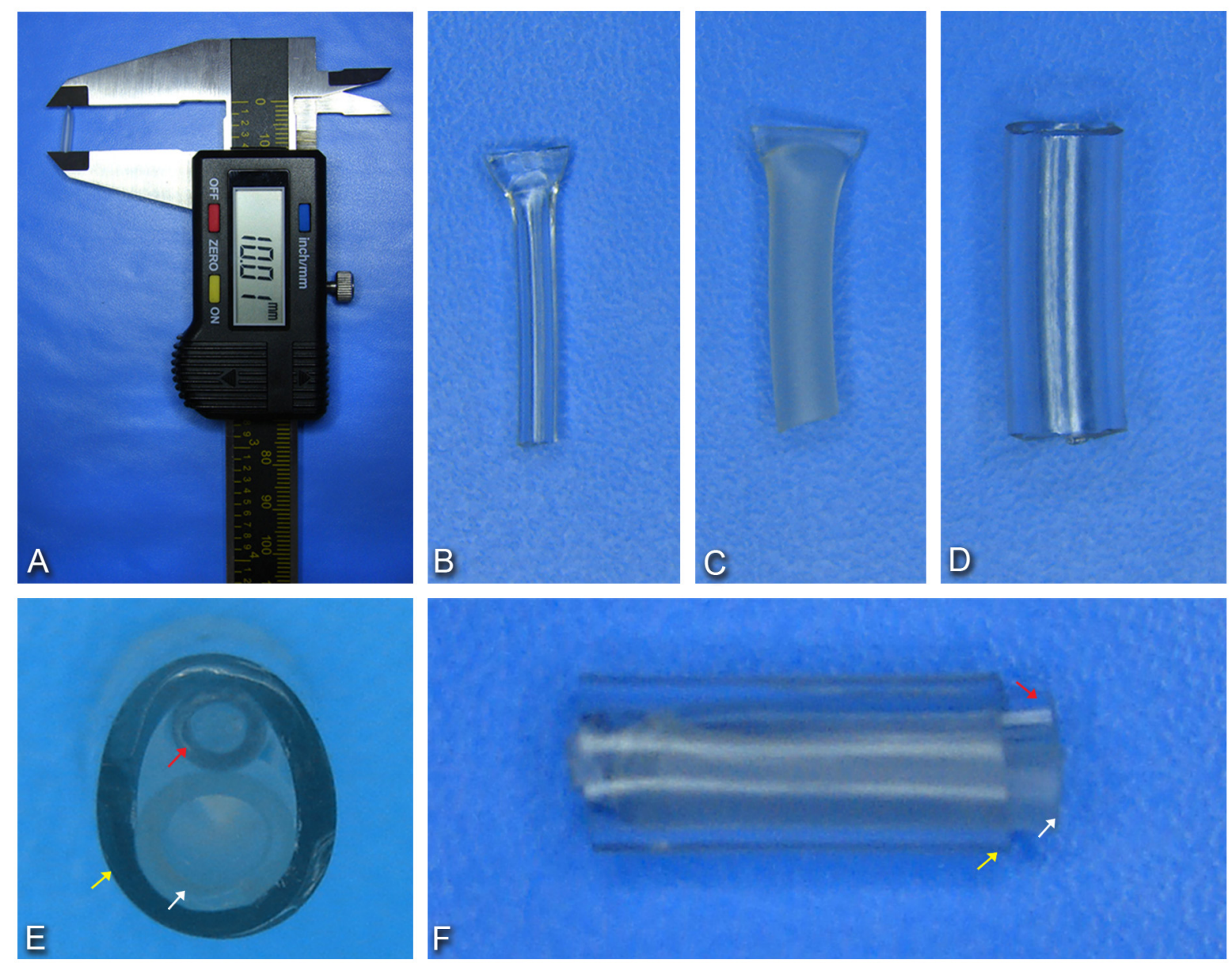

Figura 1 (A) paquímetro digital utilizado para a padronização do comprimento dos tubos, (B) tubo de calibre 4 com uma das extremidades fechadas, (C) tubo de calibre 6 com uma das extremidades fechada, (D) tubo de calibre $12,(E, F)$ implante com os tubos de calibre 4 seta vermelha, calibre 6 seta branca e calibre 12 seta amarela. 



\subsection{Preparo dos Aplicadores}

Os aplicadores foram confeccionados a partir de uma adaptação feita em seringas de $1 \mathrm{~mL}$. Para isso, duzentas e quarenta seringas terão sua extremidade cortada com o auxilio de um disco diamantado montado em mandril e peça reta como demonstrado na figura 2A. Após o preparo, o implante foi acondicionado no interior de cada seringa tomando-se o cuidado de deixar a frente do mesmo voltada para a abertura da seringa (2B). O conjunto aplicador mais implante foi embalado de forma apropriada para a esterilização por óxido de etileno (figura 2C).
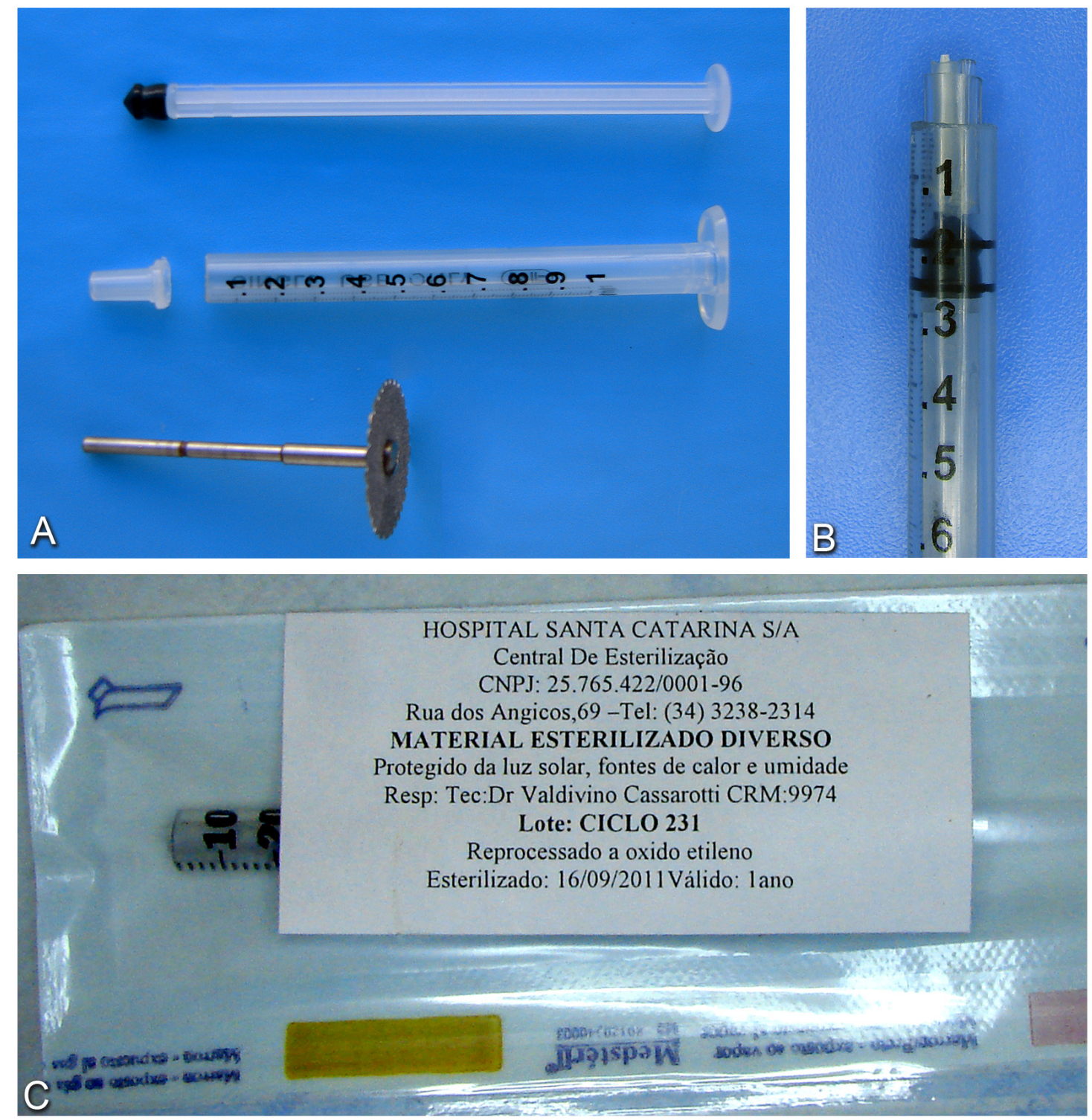

Figura 2. (A) seringa de $1 \mathrm{ml}$ com a extremidade cortada e disco diamantado montado em mandril para peça reta; (B) implante no interior do aplicador; (C) conjunto aplicador e implante embalados e esterilizados por óxido de etileno. 



\subsection{Preparo dos implantes para instalação}

O conjunto implante e aplicador foi aberto dentro de uma zona asséptica, formada por 3 lamparinas (Figura 3A) onde a esponja foi embebida com $5 \mu$ l de PBS fisiológico ou da solução de Lipopolissacarideo (LPS) de Escherichia coli (Serotype 055:B5 Sigma - Aldrich Sigma Chemical CO. St. Louis, MO, USA) preparada pela dissolução de $10 \mathrm{mg}$ de LPS em $1 \mathrm{ml}$ de phosphate buffer saline (PBS) estéril obtendo-se uma concentração de $10 \mathrm{mg} / \mathrm{ml}$ (Figura 3B) e o tubo vazio foi preenchido com o cimento a ser testado (Figura $3 \mathrm{C}$ ) ou permaneceu vazio para os grupos controle.
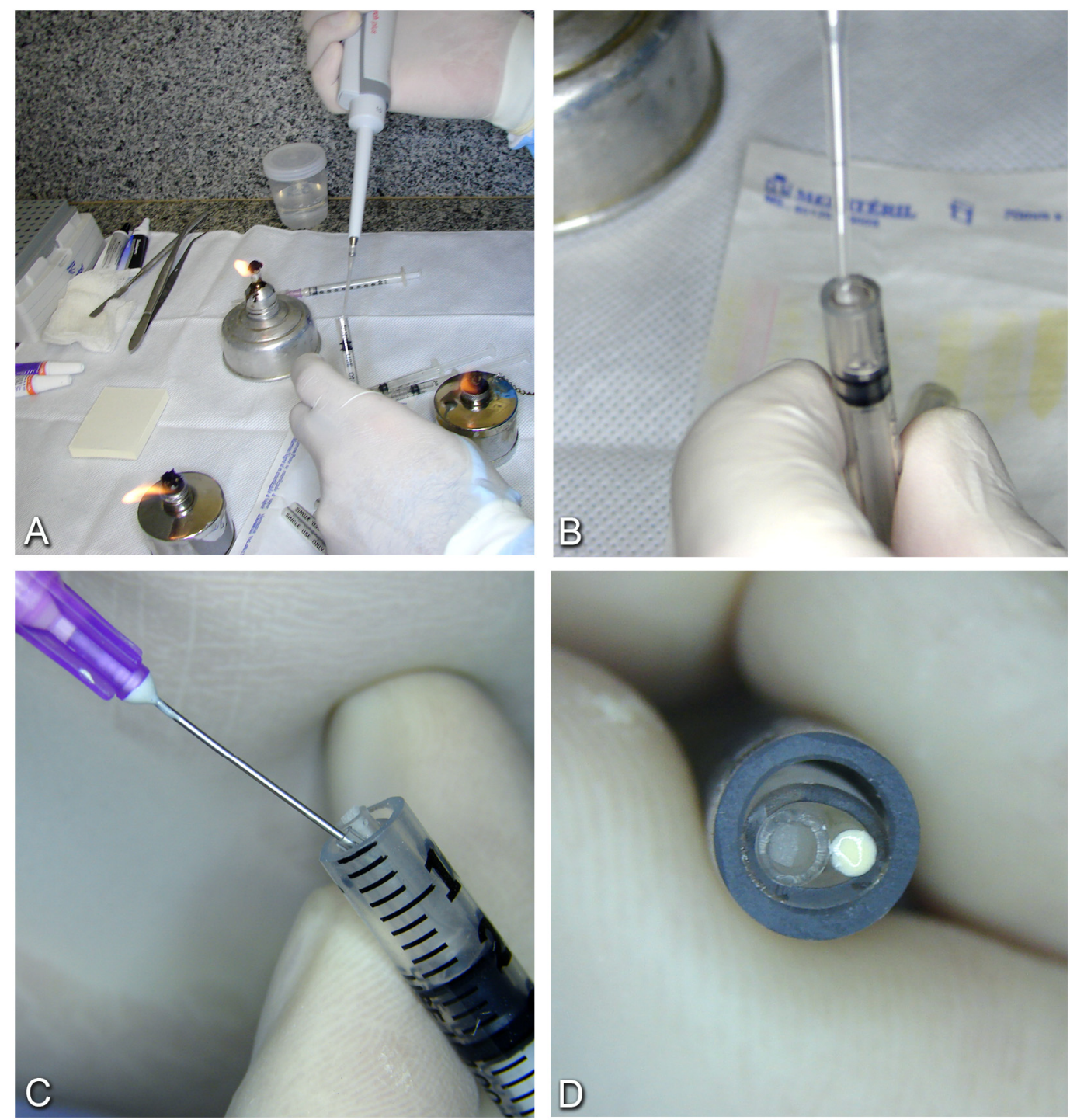

Figura 3. (A) zona assépitica formada pela chama de três lamparinas; (B) esponja sendo embebida com $5 \mu$ l de PBS fisiológico ou da solução de Lipopolissacarideo; (C) tubo sendo preenchido com o cimento endodôntico a ser testado; (D) implante pronto para instalação. 



\subsection{Procedimento Operatório}

Os animais foram anestesiados com a associação de cetamina $10 \% 25 \mathrm{mg} / \mathrm{kg}$ e xilazina 2\% 10mg/kg, injetado intraperitonealmente (Figura 4A). Estando os animais anestesiados, o pelo do dorso foi removido e a anti-sepsia foi realizada com solução alcoólica de iodo a 2\% (Figura 4B). Nessas regiões, foram feitas duas incisões de aproximadamente $1 \mathrm{~cm}$ com o auxilio de uma tesoura cirúrgica (Figura $4 \mathrm{C}$ ), seguida da divulsão do tecido com uma tesoura romba e descolador de Molt. Após a confecção das lojas cirúrgicas, os implantes foram colocados com o auxílio do aplicador utilizando a marcação da seringa para padronizar a distância do implante à incisão de aproximadamente $3 \mathrm{~cm}$ (Figura 4E seta). As incisões foram suturadas com fio de seda 4-0 (JOHNSON \& JOHNSON, Sorocaba, SP, Brasil.) (Figura 4F). Os pontos foram removidos quando necessário, 7 dias após a intervenção. 


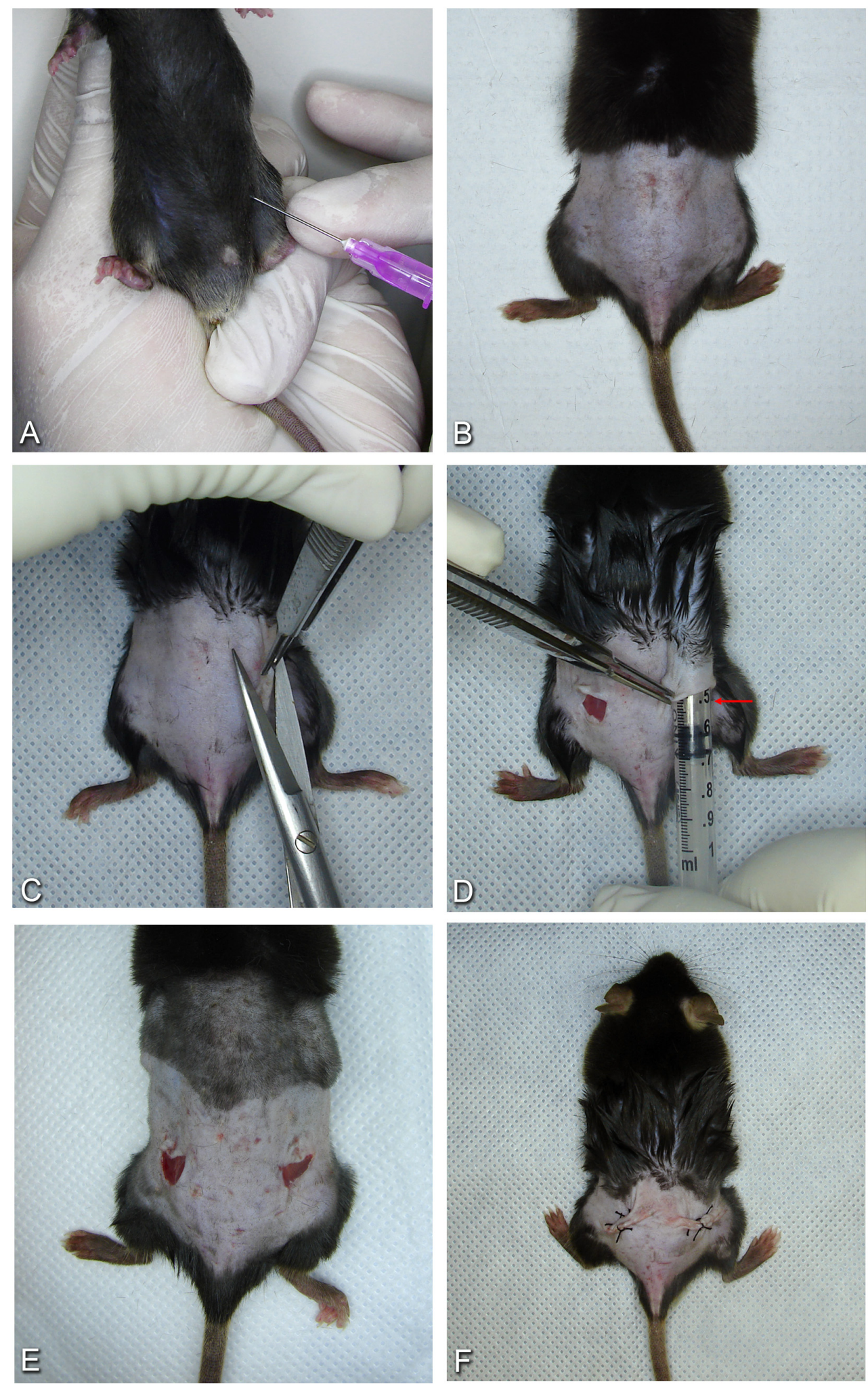

Figura 4 (A) anestesia com a associação de cetamina 10\% 25mg/kg e xilazina 2\% $10 \mathrm{mg} / \mathrm{kg}$, injetado intraperitonealmente; (B) remoção dos pelos do dorso; (C) incisão realizada com tesoura cirurgica; (D) instalação dos implantes, a seta corresponde a marcação da distância entre o local de peposição do implante e a incisão (aproximadamente $3 \mathrm{~cm}$ ); (E) implantes em posição; (F) sutura com fio de seda 4-0 (JOHNSON \& JOHNSON, Sorocaba, SP, Brasil.). 

Os animais foram mantidos no Biotério da Faculdade de Odontologia de Ribeirão Preto - USP em caixas plásticas $(41 \times 34 \times 16 \mathrm{~cm}$ ) (5 animais por caixa) em ambiente com temperatura local mantida a $24 \pm 0,5^{\circ} \mathrm{C}$, controlada por condicionador de ar quente/frio, e umidade natural. A iluminação foi automatizada, controlada por timer, com ciclo de $12 \mathrm{~h}$ claro/12 h escuro. Os animais receberam alimentação (ração) e água filtrada à vontade. Durante os períodos experimentais, eles foram monitorados periodicamente para a observância de qualquer anormalidade.

Após cada período experimental (7, 21 e 63 dias), os animais foram anestesiados para a remoção dos implantes e tecidos subjacentes sendo em seguida sacrificados por deslocamento cervical. Os implantes foram removidos cortando-se a pele em sua volta, obtendo-se um tecido de formato retangular com o implante situado ao centro (Figura 5A). As amostras foram divididas da seguinte forma: duas amostras de cada grupo foram enviadas para o processamento histotécnico de rotina preservando o implante no interior do tecido (Figura 6) e com as oito amostras restantes foi realizada a remoção do implante tomando se o cuidado de remove-lo pela parte inferior (Figura 5B). Após a remoção do implante o excesso de tecido foi descartado (Figura 5C) e apenas a faixa de tecido correspondente ao implante (Figura 5D) foi embalada individualmente em papel alumínio e congeladas a $-70^{\circ} \mathrm{C}$ para posterior processamento para a dosagem de citocinas. 


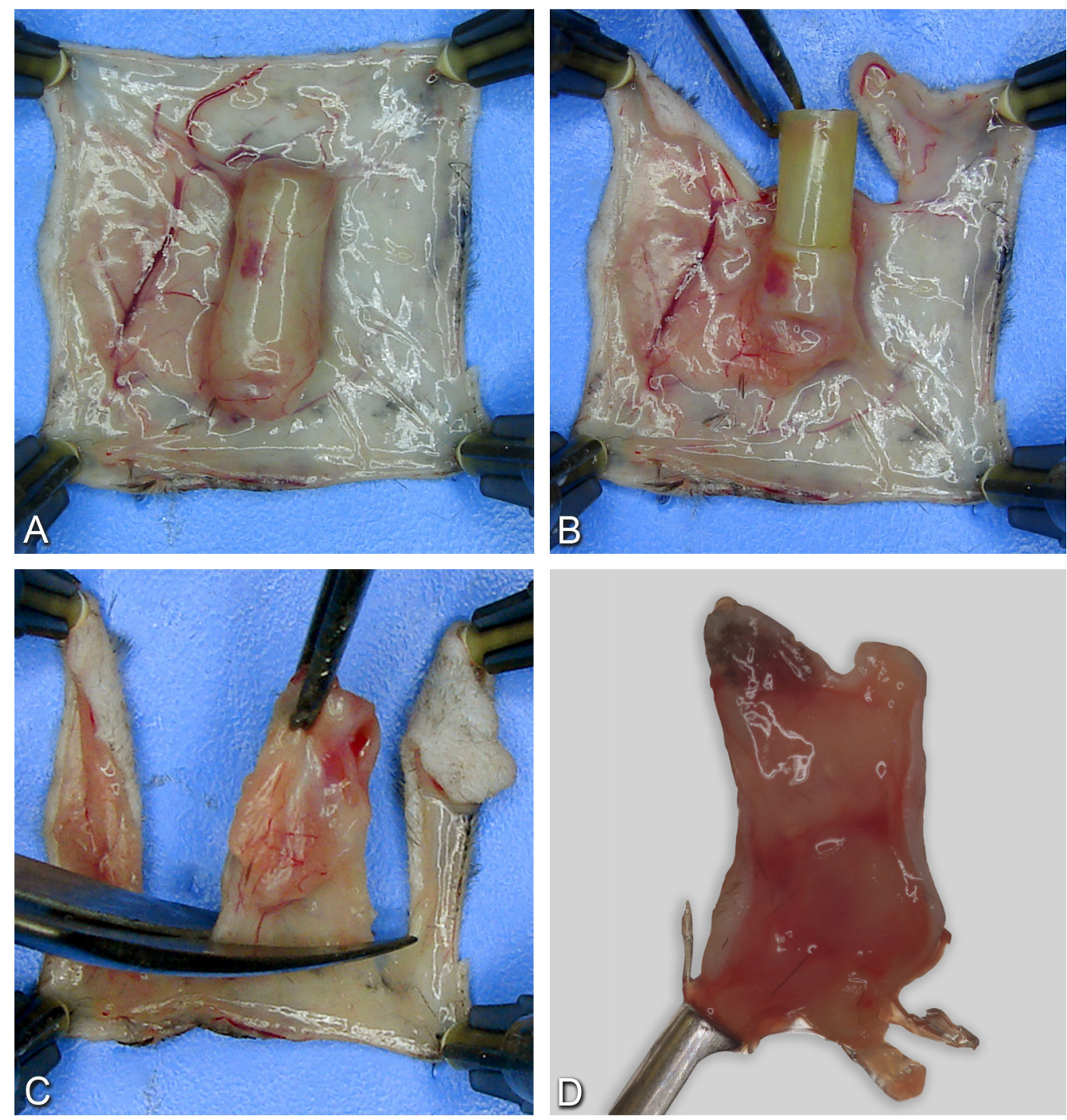

Figura 5 (A) tecido removido de formato retangular com o implante situado ao centro; (B) remoção do implante pela base; (C) remoção do excesso de tecido; (D) tecido correspondente ao implante.

\subsection{Processamento Histológico e análise microscópica descritiva}

Os materiais removidos foram fixados por 48 horas em solução tamponada de formol a $10 \%$ processados e incluídos em blocos de parafina para cortes seriados com 5 micrometros de espessura. Para cada bloco, foram obtidas séries de 8 lâminas com dois cortes cada a partir do ponto em que foi possível observar o implante com intervalo entre as séries de 200 micrometros. A primeira e quinta lâminas de cada séries lâminas serão coradas com hematoxilina e eosina ( $\mathrm{H} \& \mathrm{E})$ as demais foram guardadas para estudos futuros. Os cortes foram realizados paralelos ao longo eixo do implante. 

Os espécimes foram analisados no microscópio Olympus ${ }^{\circledR}$ FSX 100 binocular utilizando objetivas de 4.2 e 20X. Em seguida foi efetuada a análise descritiva.

Nesta etapa da pesquisa foi selecionada uma lâmina representativa de cada grupo onde foi descrita a reação tecidual observada frente aos materiais testados nos diferentes períodos experimentais, sem especificar cada um dos espécimes, mas sim caracterizando o grupo como um todo.
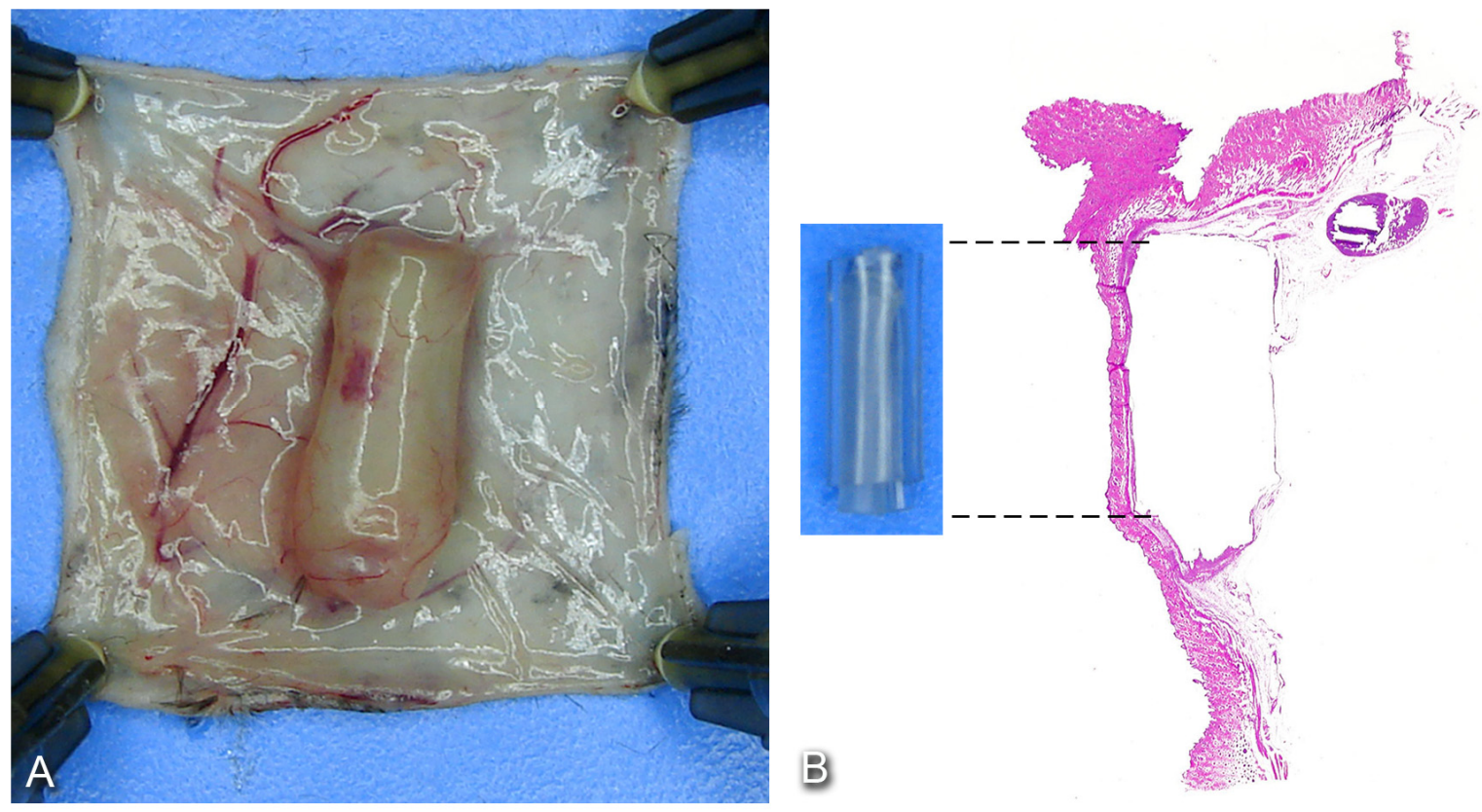

Figura 6 (A) tecido removido de formato retangular com o implante situado ao centro; (B) foto esquemática demosntrando a posição do implante em relação ao tecido.

\subsection{Processamento para a dosagem de citocinas}

Após todos os tempos experimentais, as amostras para a quantificação de citocinas foram pesadas e homogeneizadas em $0.5 \mathrm{ml}$ de uma solução formada por $0.480 \mathrm{ml}$ de tampão de lise RIPA ${ }^{2}$ associado a $0.020 \mathrm{ml}$ da solução de inibidor de protease ${ }^{3}$. O sobrenadante foi utilizado para as dosagens, após a centrifugação a 10.000 Kgf por 10 minutos a $4^{\circ} \mathrm{C}$.

\footnotetext{
${ }^{2}$ Tris-HCL 10mM, pH= 7.4; EDTA 5mM; NACl 150 mM; Triton X-100 1\%; deoxicolato de sódio 1\%; SDS 0,1\%; aprotinina $1 \%$ e $\mathrm{NA}_{3} \mathrm{VO}_{4} 0,1 \mathrm{mM}$.

${ }^{3}$ Complete, EDTA-free - Protease Inhibitor Cocktail Tablets Roche ${ }^{\circledR} 1$ comprimido dissolvido em 2 ml de PBS ph 7,0 .
} 


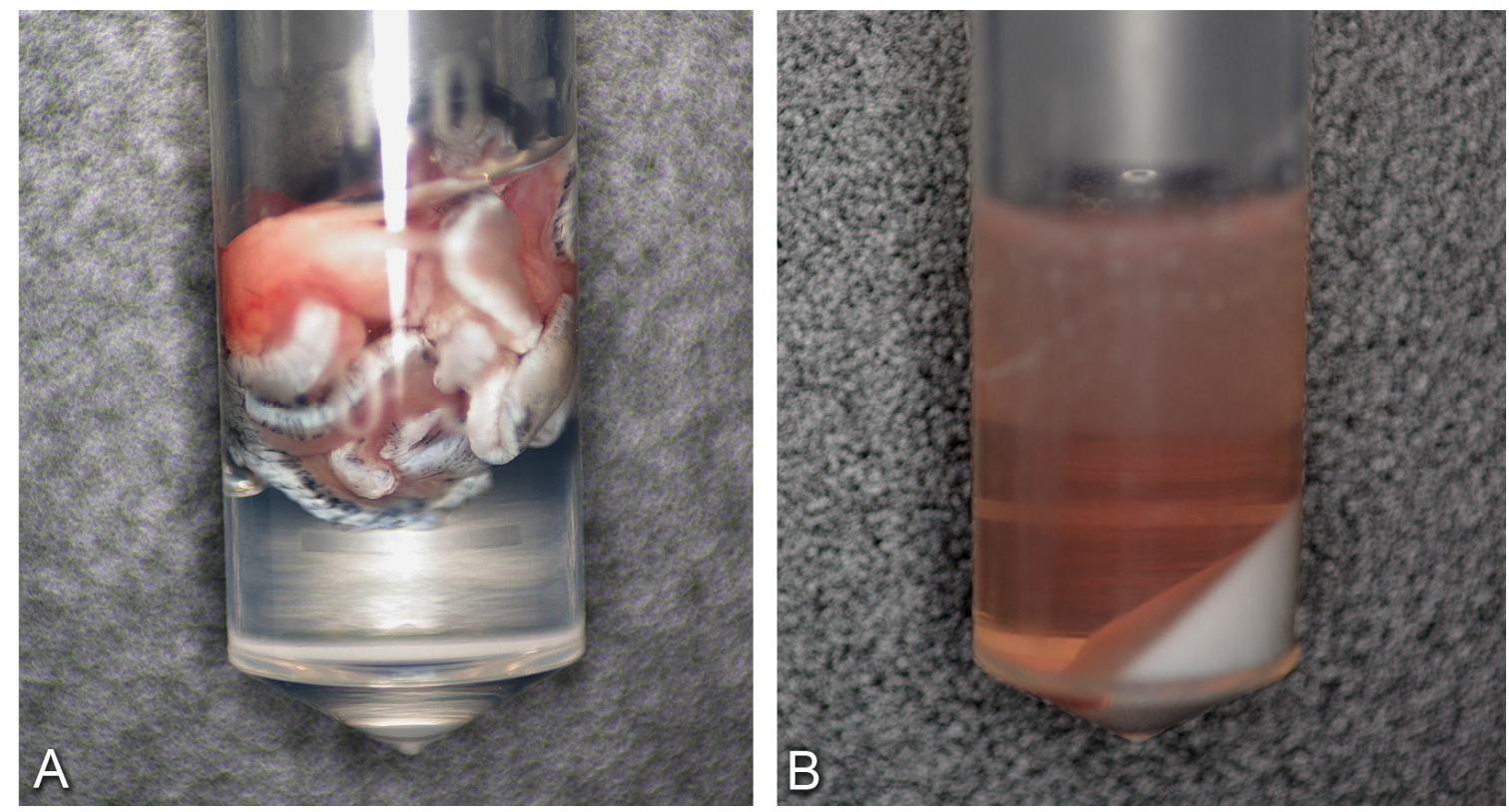

Figura 7 (A) amostra em $0.5 \mathrm{ml}$ de uma solução formada por $0.480 \mathrm{ml}$ de tampão de lise RIPA associado a $0.020 \mathrm{ml}$ da solução de inibidor de protease; (B) amostra após a homogenização e centrigugação.

A dosagem das citocinas interleucina-6 (IL-6), Interleucina-10 (IL-10), Interleucina2 (IL-2), Interleucina-4 (IL-4), Interleucina-17A (IL-17A), Interferon- $\gamma$ (IFN- $\gamma$ ) e Fator de Necrose Tumoral-a (TNF-a) foi feita com o kit CBA mouse-Th1/Th2/Th17 Cytokine Kit (BD Cytometric Bead Array, San Jose, CA, USA).

O kit CBA é composto por uma única população de mesmo tamanho de partículas, as quais possuem intensidade de fluorescência distinta conforme a citocina a ser mensurada. Além da fluorescência, cada partícula é revestida por anticorpos específicos para cada citocina. A detecção das citocinas será realizada através da adição de anticorpos específicos conjugados com fluorescência. A quantificação em pg/mg de cada citocina será baseada em uma curva padrão, realizada com diluições conhecidas, o que possibilitará a construção de um gráfico de intensidade de PE versus $\mathrm{pg} / \mathrm{mg}$. A equação gerada a partir deste gráfico possibilitará o cálculo da concentração das citocinas nas amostras. A leitura do teste CBA foi realizada em citômetro de fluxo e para a análise dos resultados foi utilizado o programa FCAP array. 



\subsection{Análise estatística}

Os dados foram analisados utilizando-se o programa estatístico Graph Pad Prism $5^{\circ}$ (Graph Pad Software In. San Diego, Califórnia, EUA). Os parâmetros foram o material implantado em função da quantidade de citocina detectada em cada período experimental. Para realizar esta comparação utilizou-se o teste $t$ com a correção Welch's quando a comparação das variâncias pelo teste $f$ mostrou-se significativa. $O$ nível de significância adotado foi de $5 \%$. 

Resultados 



\section{RESUltados}

\subsection{Análise Microscópica descritiva}

A análise miscroscópica descritiva não teve por objetivo a comparação das amostras entre os materiais testados. Desta forma não foram realizados comparações qualitativas ou quantitativas entre eles. Realizou-se esta análise apenas com o intuito de fornecer informações a respeito do quadro histológico colaborando com a interpretação dos resultados obtidos pelo CBA na quantificação das citocinas.

\section{Grupo I - Tubo vazio com PBS - 7 dias (Figura 8)}

O corte representativo do grupo mostrou a formação de tecido reacional à frente do tubo assim como uma estrutura capsular envolvendo todo o implante. A análise microscópica demonstrou a presença de uma faixa de necrose seguida de uma camada de fibroblastos com formação de fibras colágenas, permeados por macrófagos, plasmócitos e neutrófilos. Observou-se presença intensa de vaso dilatados e hiperêmicos.
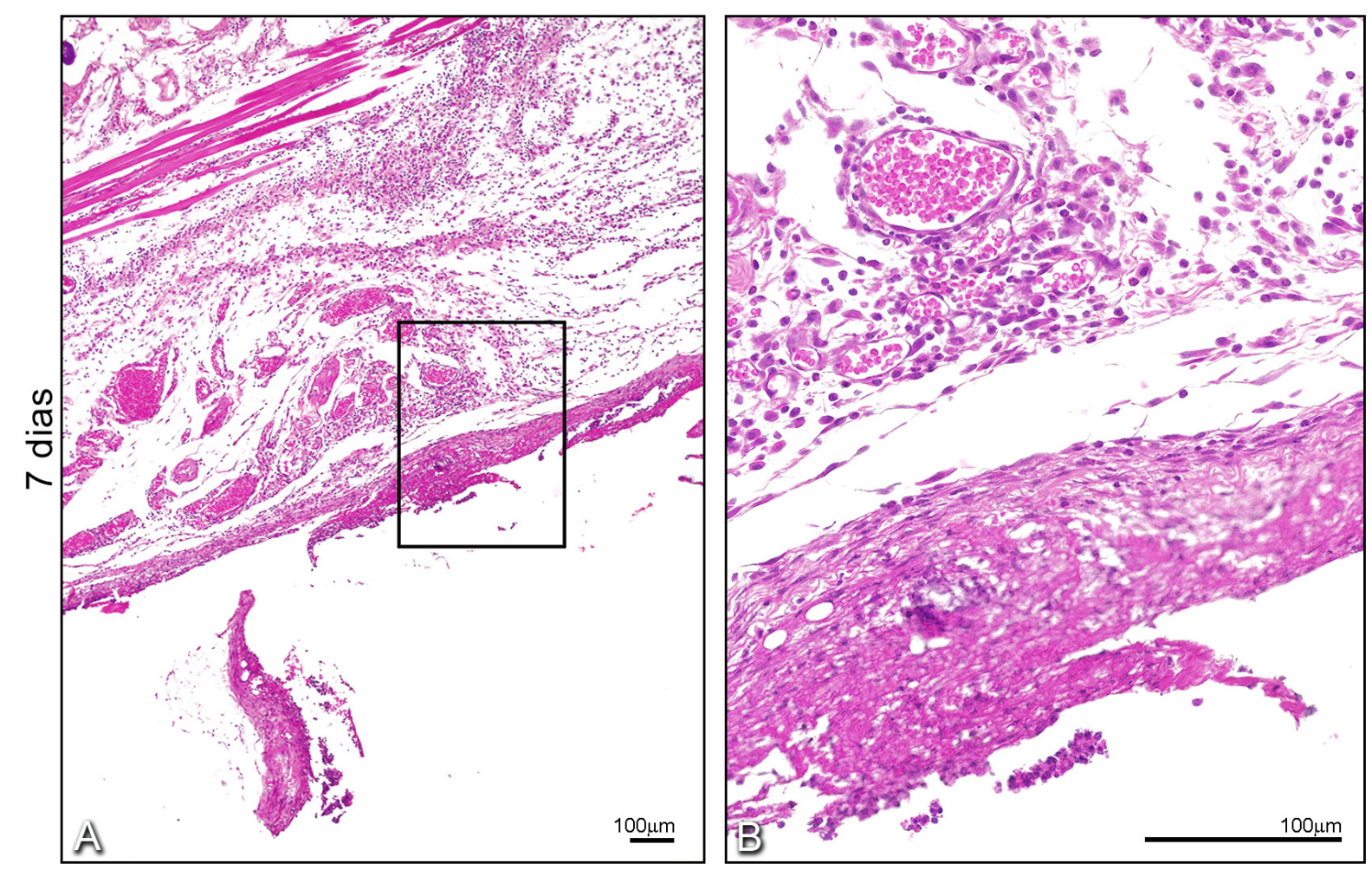

Figura 8 Grupo I - Aspectos microscópicos da reação do tecido conjuntivo subcutâneo de camundongos frente ao implante. (A) Corte histológico corado em HE, objetiva de 4,2X; (B) área destacada da figura (A) objetiva de 20X. 



\section{Grupo II - Tubo vazio com LPS - 7 dias (Figura 9)}

Neste grupo os espécimes apresentaram intenso infiltrado inflamatório à frente do tubo, com a presença intensa de macrófagos, células gigantes multinucleadas, neutrófilos polimorfonucleares e plasmócitos. Foi constatada grande neoformação vascular e fibrosamento sem caracterizar uma cápsula contínua e organizada.
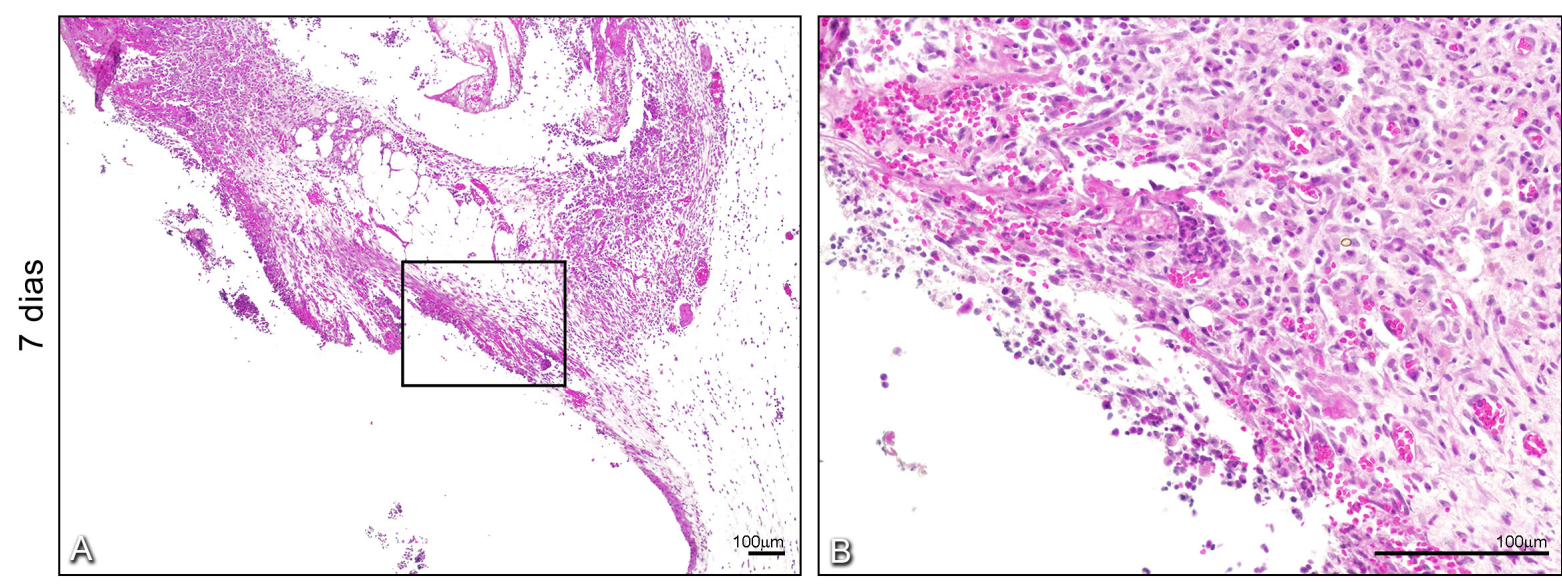

Figura 9 Grupo II - Aspectos microscópicos da reação do tecido conjuntivo subcutâneo de camundongos frente ao implante. (A) Corte histológico corado em HE, objetiva de 4,2X; (B) área destacada da figura (A) com objetiva de $20 x$. 



\section{Grupo III - Sealapex ${ }^{\circledR}$ com PBS - 7 dias (Figura 10)}

A interface com o material testado mostrou a presença de infiltrado inflamatório, com a presença de macrófagos neutrófilos. Havia também a presença de fibroblastos. Nos espécimes representativos avaliados foi possível detectar hemorragia por rexe e vasos sanguineos dilatados. O tecido reacional está subjacente ao tecido adiposo.
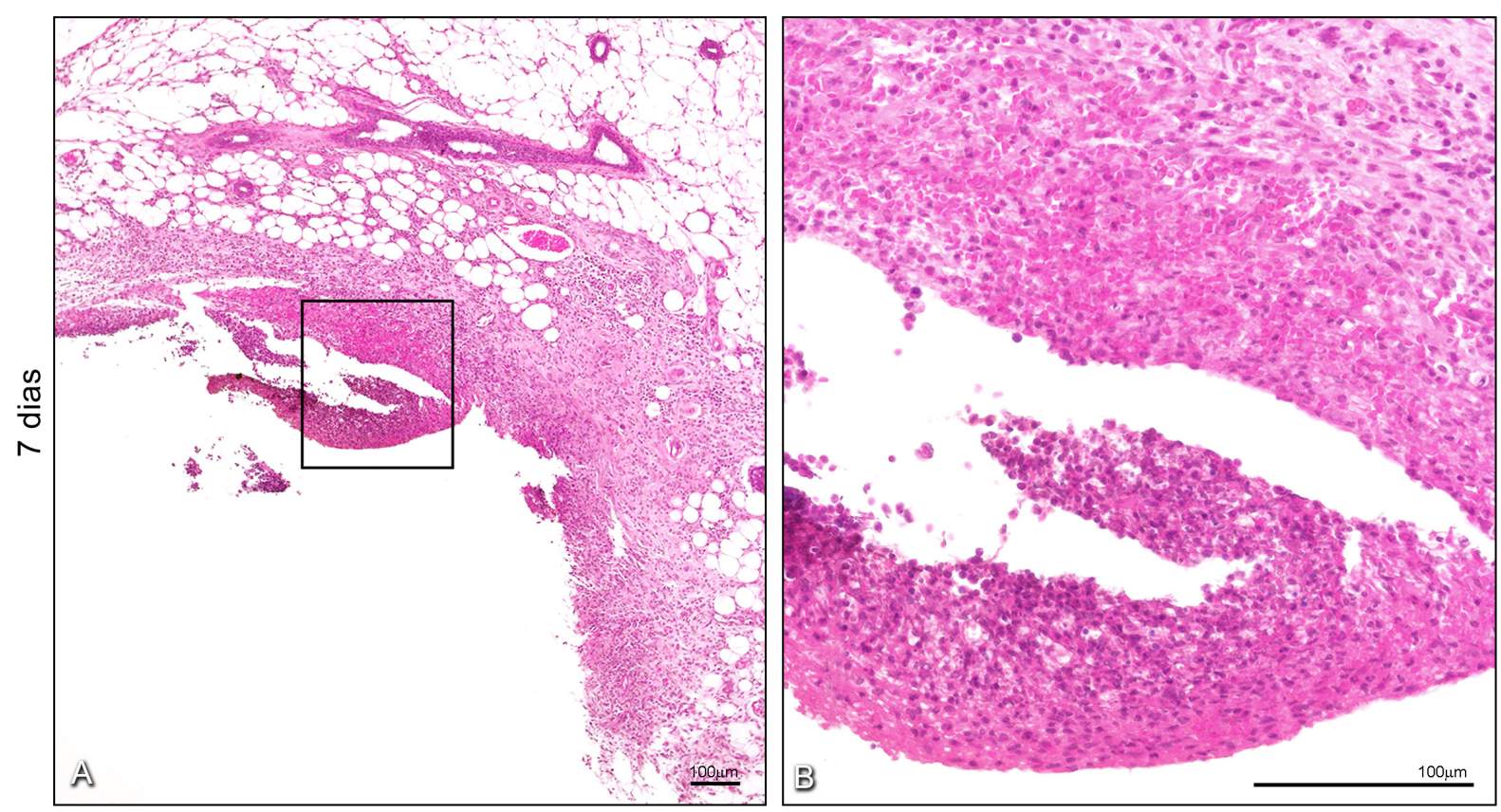

Figura 10 Grupo III - Aspectos microscópicos da reação do tecido conjuntivo subcutâneo de camundongos frente ao implante. (A) Corte histológico corado em HE, objetiva de 4,2X; (B) área destacada da figura (A) com objetiva de $20 x$. 



\section{Grupo IV - Sealapex ${ }^{\circledR}$ com LPS - 7 dias (Figura 11)}

A resposta tecidual ao cimento Sealapex ${ }^{\circledR}$ na presença do LPS caracterizou-se por apresentar uma grande quantidade de neutrófilos polimorfonucleares. Presença intensa de fibroblastos sem o aspecto de um fibrosamento uniforme apresentando-se ora mais espesso ora mais delgado. No espécime representativo foi possível detectar a presença de acúmulo de linfócitos.
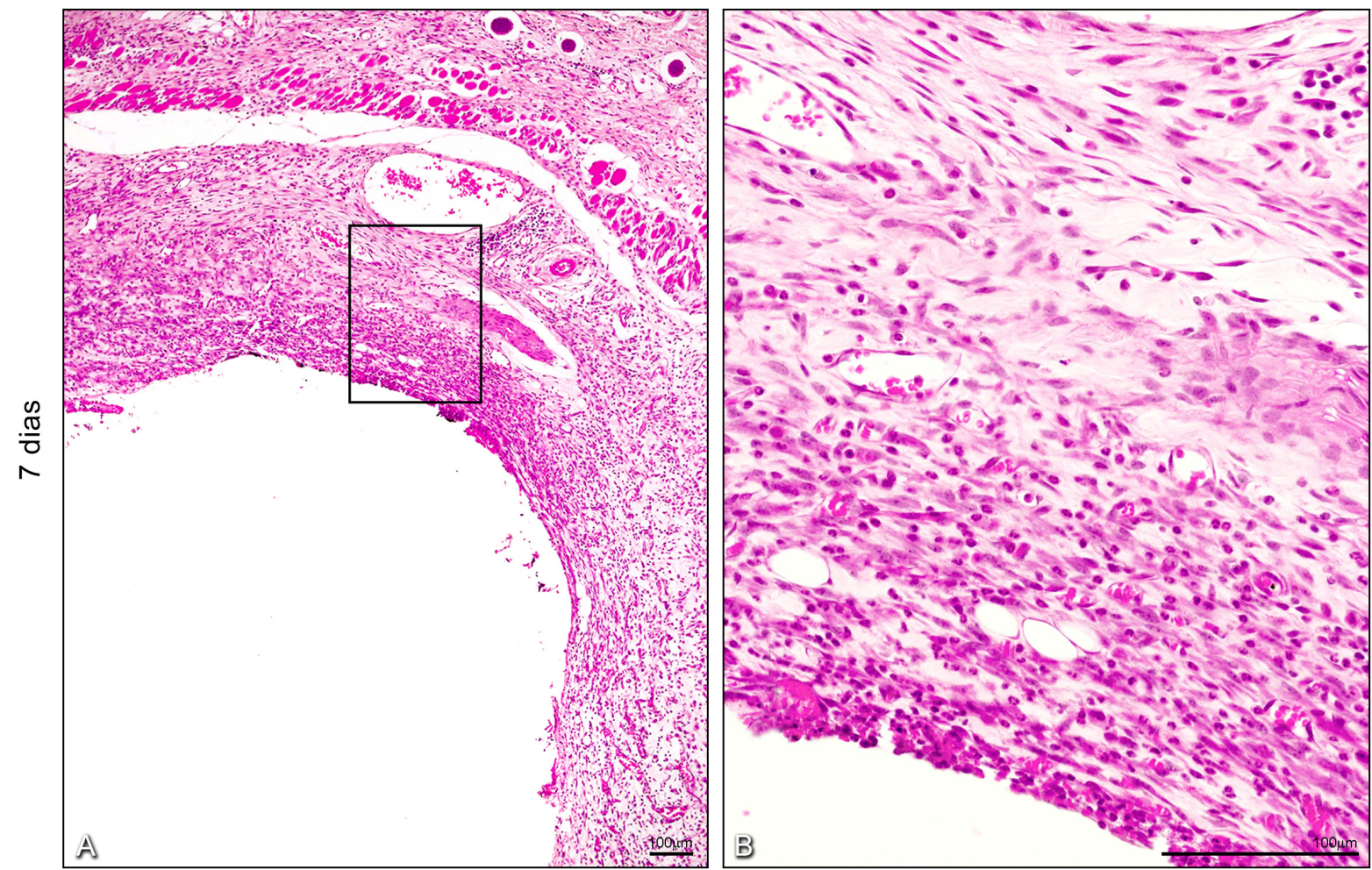

Figura 11 Grupo IV - Aspectos microscópicos da reação do tecido conjuntivo subcutâneo de camundongos frente ao implante. (A) Corte histológico corado em HE, objetiva de 4,2X; (B) área destacada da figura (A) com objetiva de $20 \mathrm{X}$. 



\section{Grupo V - Activ GP ${ }^{\circledR}$ com PBS - 7 dias (Figura 12)}

Os espécimes examinados apresentaram a formação de tecido reacional onde um grande número de células em contato com 0 material foram caracterizadas morfologicamente como macrófagos e neutrófilos. Presença moderada de vasos sanguíneos além de áreas com condensação de fibras colágenas.
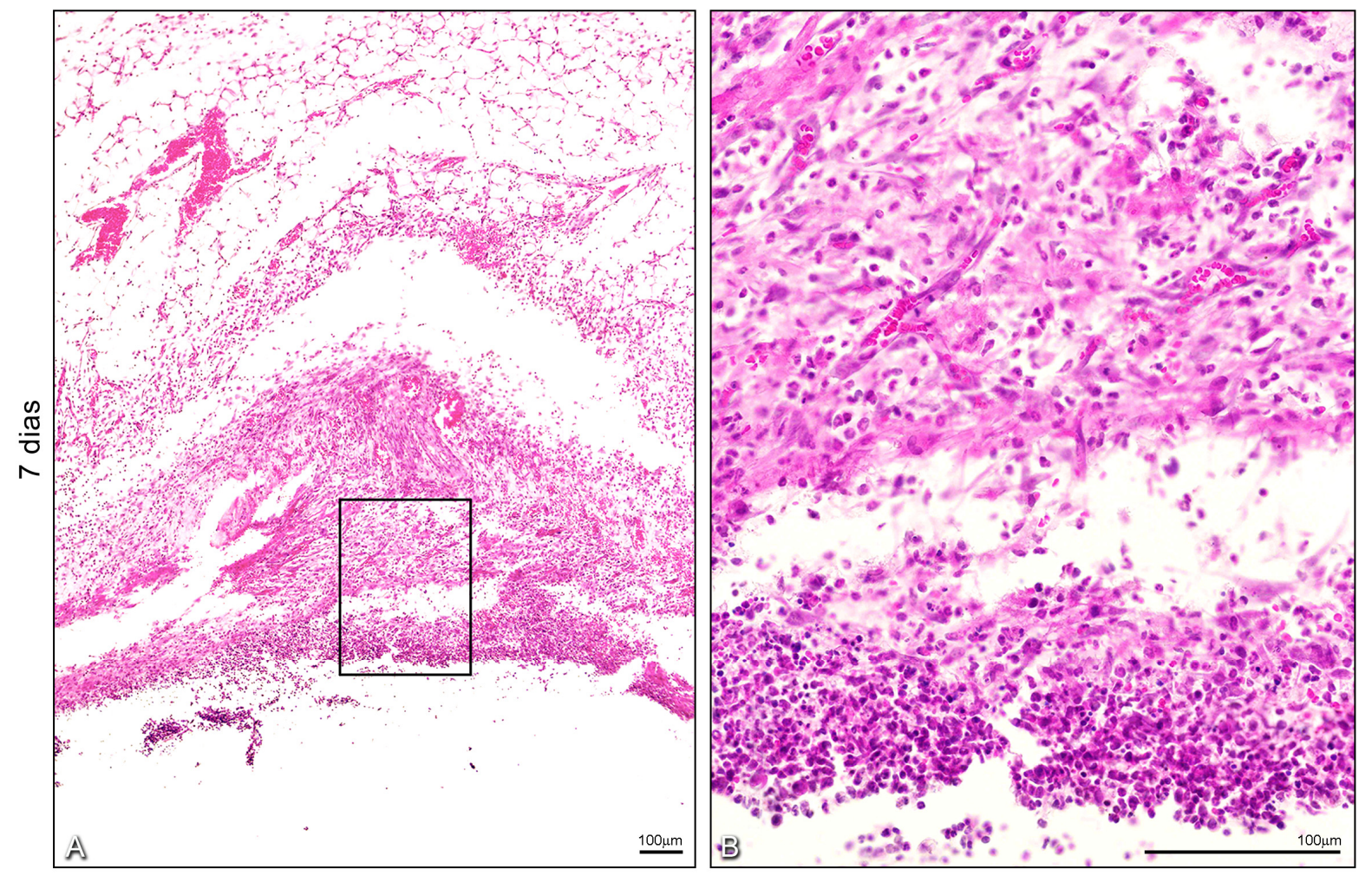

Figura 12 Grupo V - Aspectos microscópicos da reação do tecido conjuntivo subcutâneo de camundongos frente ao implante. (A) Corte histológico corado em $\mathrm{HE}$, objetiva de 4,2X; (B) área destacada da figura (A) com objetiva de 20X. 



\section{Grupo VI - Activ GP ${ }^{\circledR}$ com LPS - 7 dias (Figura 13)}

Neste grupo houve uma resposta inflamatória mais intensa. Pode-se observar frente ao material testado uma faixa de necrose com a presença de uma camada subjacente de fibroblastos, macrófagos e neutrófilos. Presença de neoformação vascular e hemorragia por rexe.
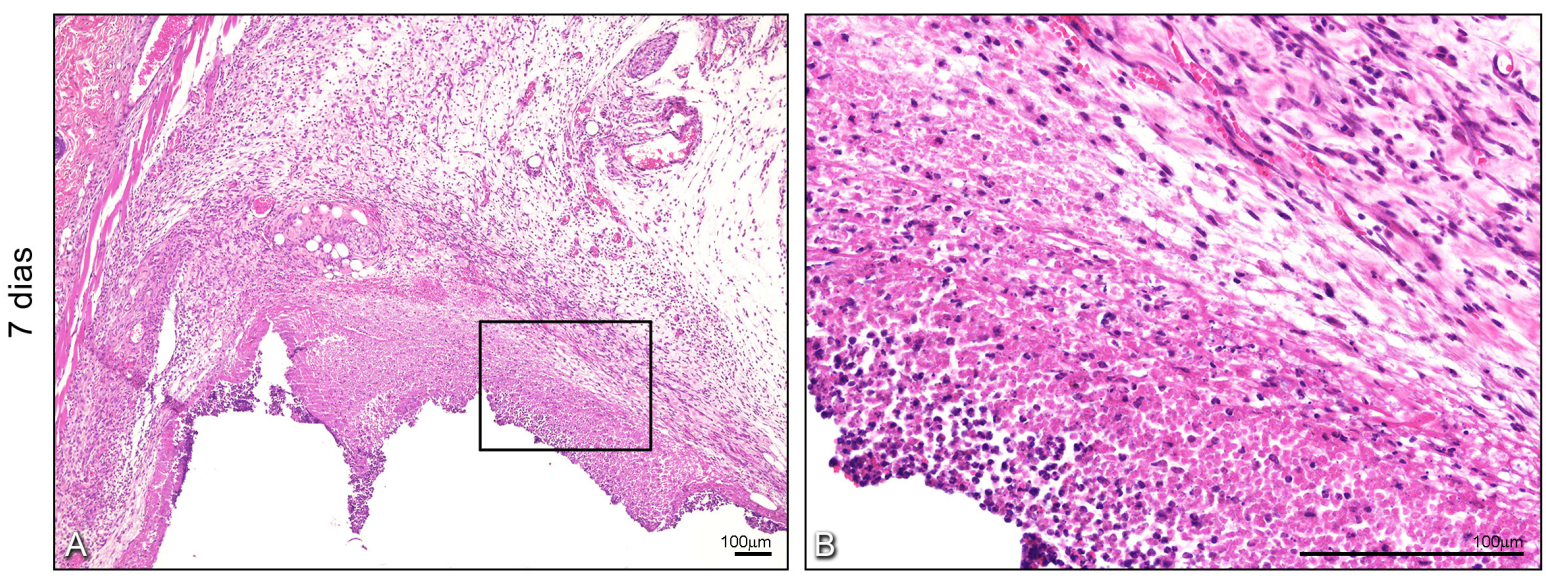

Figura 13 Grupo VI - Aspectos microscópicos da reação do tecido conjuntivo subcutâneo de camundongos frente ao implante. (A) Corte histológico corado em $\mathrm{HE}$, objetiva de 4,2X, (B) área destacada da figura (A) com objetiva de 20X. 



\section{Grupo VII - AH-PIus ${ }^{\circledR}$ Com PBS - 7 dias (Figura 14)}

Os espécimes representativos do grupo mostraram a presença de infiltrado inflamatório caracterizado pela presença abundante de macrófagos com o citoplasma vacuolado. Presença de células gigantes multinucleadas e pequena incidência de neutrófilos. Houve neoformação vascular de forma moderada e formação de cápsula fibrosa envolvendo o implante.
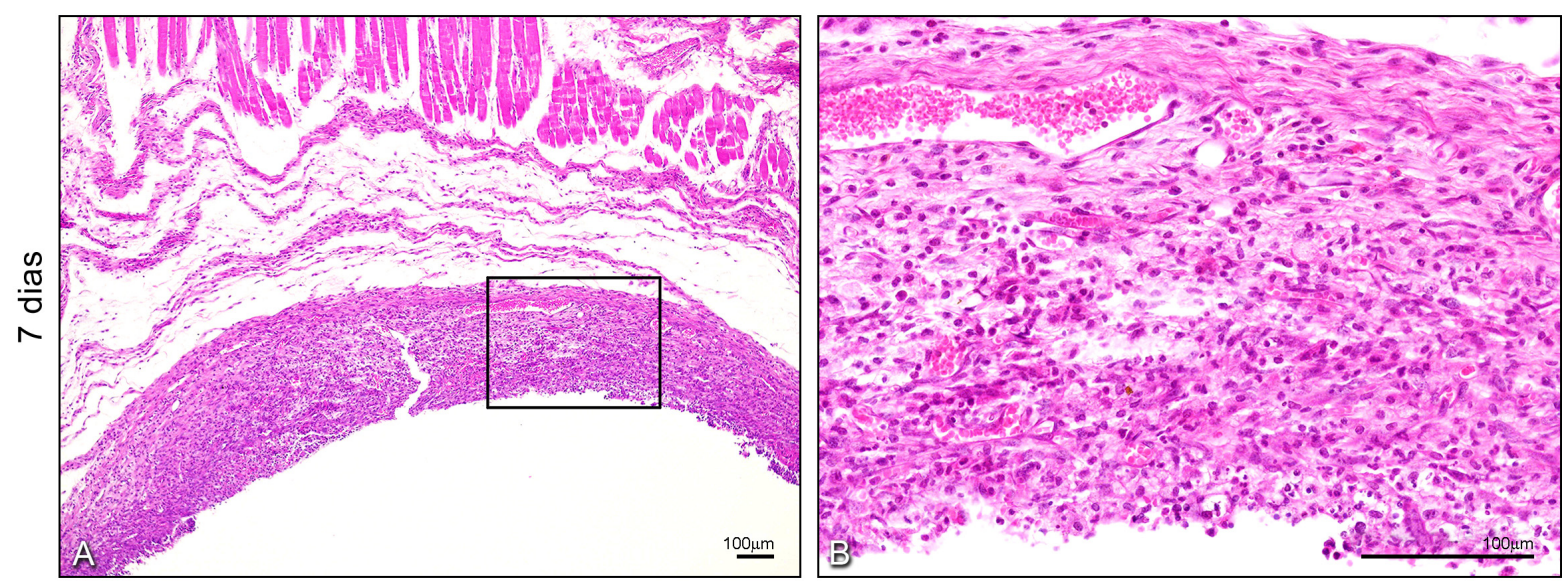

Figura 14 Grupo VII - Aspectos microscópicos da reação do tecido conjuntivo subcutâneo de camundongos frente ao implante. (A) Corte histológico corado em HE, objetiva de 4,2X; (B) área destacada da figura (A) com objetiva de 20X. 



\section{Grupo VIII - AH-PIus ${ }^{\circledR}$ com LPS - 7 dias (Figura 15)}

A resposta tecidual se caracterizou pela presença de uma faixa de tecido hialino com fragmentação celular na interface com o material. Acima desta faixa, pôde-se observar células inflamatórias com macrófagos, neutrófilos, plasmócitos e em pequena quantidade células gigantes multinucleadas. Presença de fibrosamento mas não de forma organizada e capsular.
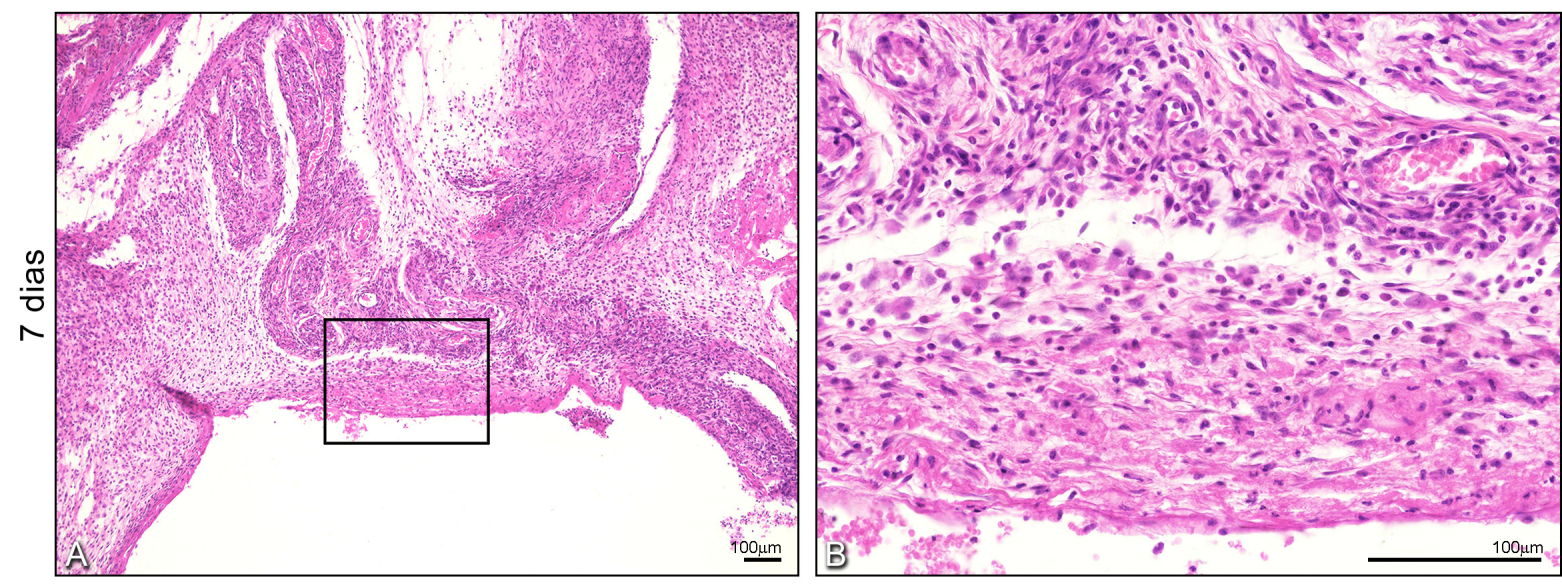

Figura 15 Grupo VIII - Aspectos microscópicos da reação do tecido conjuntivo subcutâneo de camundongos frente ao implante. (A) Corte histológico corado em HE, objetiva de 4,2X; (B) área destacada da figura (A) com objetiva de 20X. 



\section{Grupo IX - Tubo vazio com PBS - 21 dias (Figura 16)}

O tecido reacional na extremidade do tubo apresentou-se mais organizado, com um menor infiltrado inflamatório e capsula fibrosa bem delimitada. Houve diminuição da hiperemia, sendo ainda possível visualizar a presença de macrófagos e neutrófilos porém em menor quantidade.
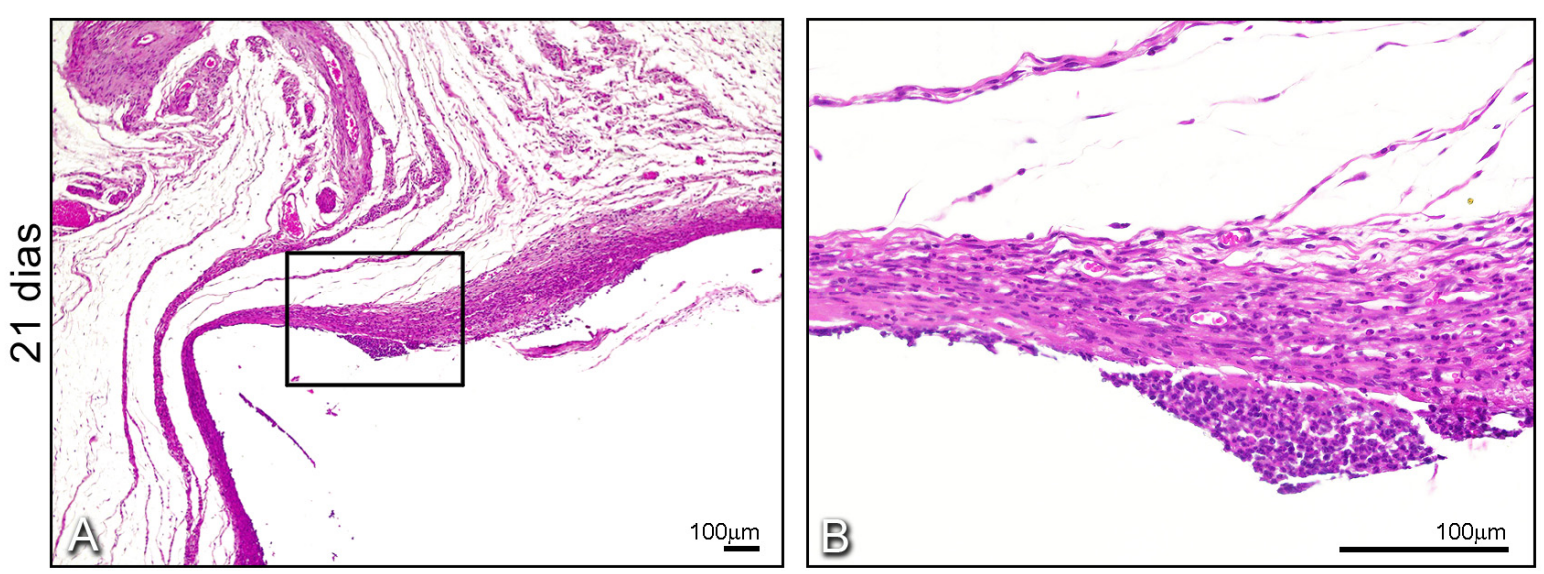

Figura 16 Grupo IX - Aspectos microscópicos da reação do tecido conjuntivo subcutâneo de camundongos frente ao implante. (A) Corte histológico corado em HE, objetiva de 4,2X; (B) área destacada da figura (A) com objetiva de $20 \mathrm{X}$.

\section{Grupo X - Tubo vazio com LPS - 21 dias (Figura 17)}

Neste grupo, o fibrosamento, na reação tecidual frente ao tubo, estava mais organizado, sendo possível visualizar o infiltrado neutrofílico, a presença de plasmócitos e macrófagos.
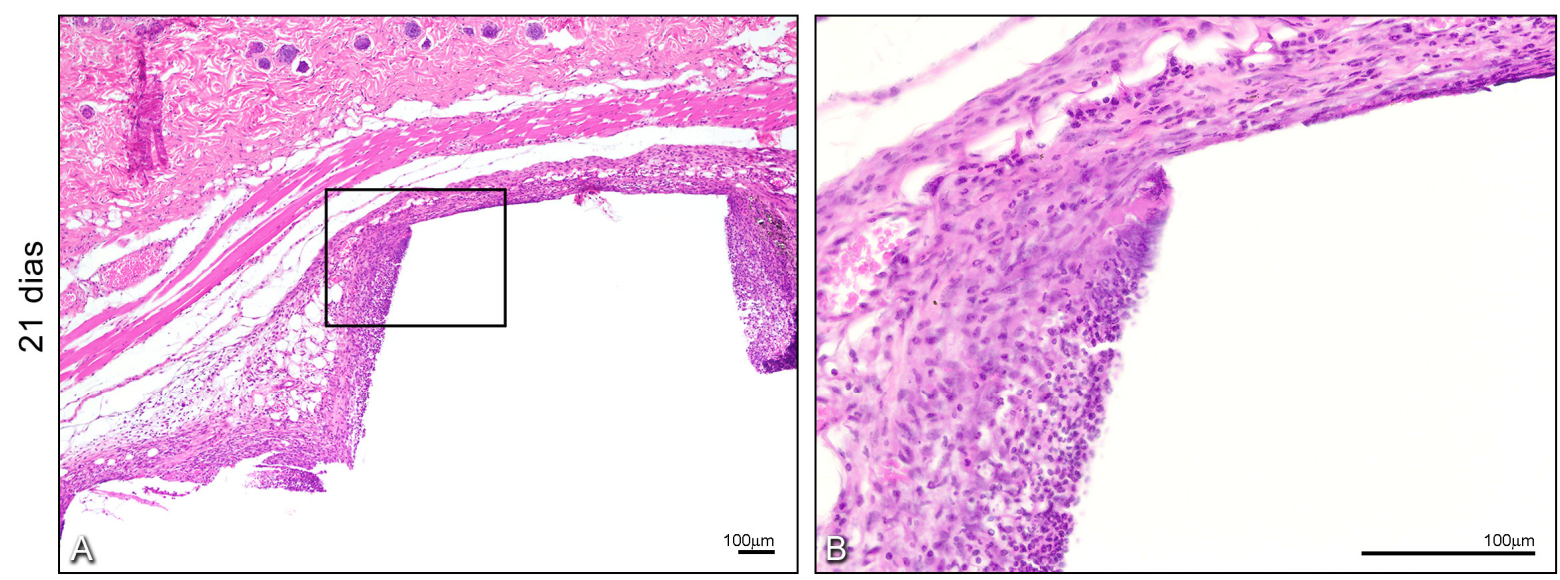

Figura 17 Grupo $X$ - Aspectos microscópicos da reação do tecido conjuntivo subcutâneo de camundongos frente ao implante. (A) Corte histológico corado em HE, objetiva de 4,2X; (B) área destacada da figura (A) com objetiva de $20 \mathrm{X}$. 



\section{Grupo XI - Sealapex ${ }^{\circledR}$ com PBS - 21 dias (Figura 18)}

O grupo XII apresentava-se com cápsula fibrosa organizada. $\mathrm{Na}$ interface do material com o tecido estava presente uma faixa de tecido hialino. Subjacente a esta faixa pode-se observar o infiltrado neutrofílico. Macrófagos e células gigantes multinucleadas foram observados de permeio ao tecido.
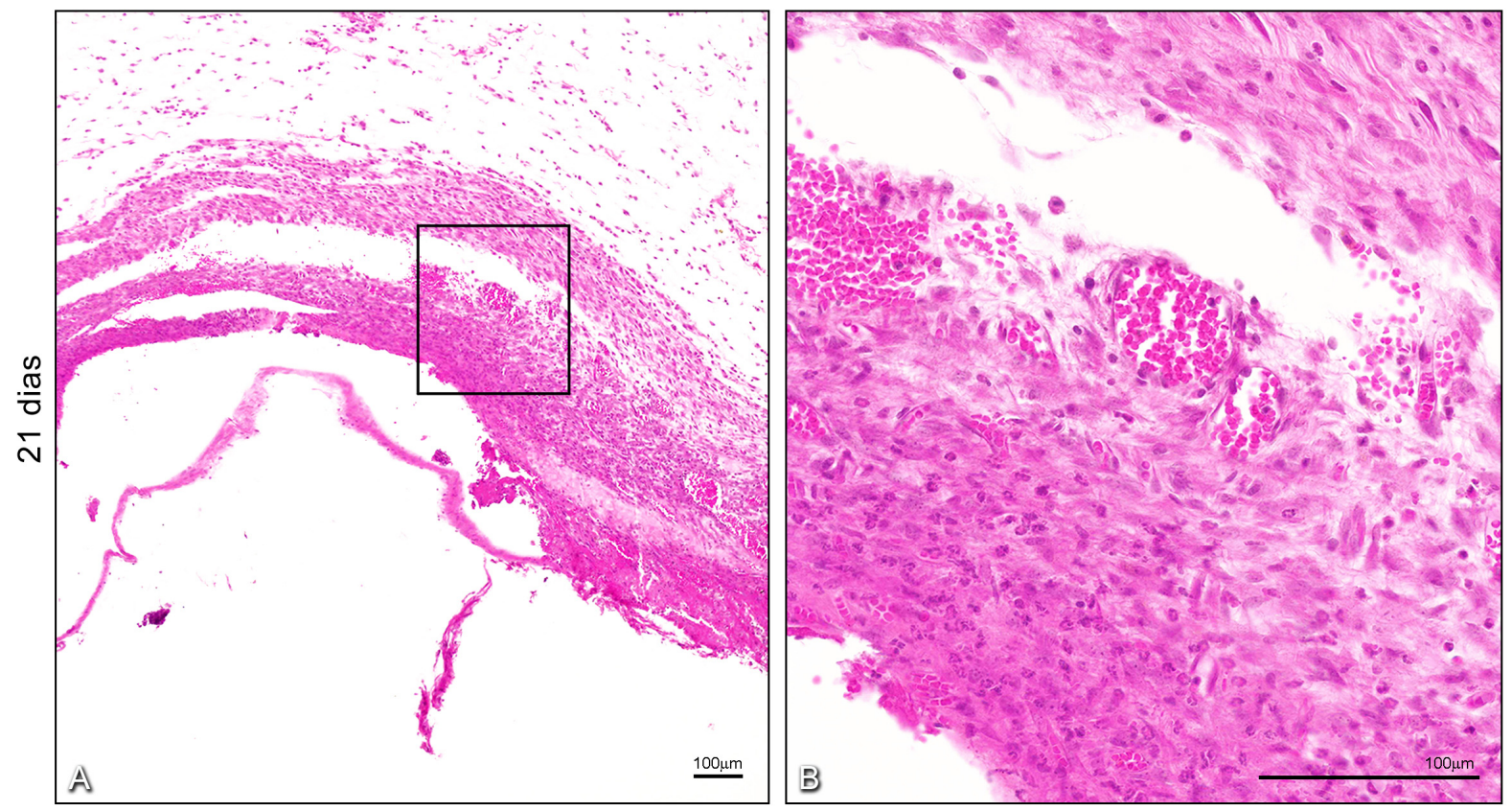

Figura 18 Grupo XI - Aspectos microscópicos da reação do tecido conjuntivo subcutâneo de camundongos frente ao implante. (A) Corte histológico corado em $\mathrm{HE}$, objetiva de 4,2X; (B) área destacada da figura (A) com objetiva de $20 \mathrm{X}$. 



\section{Grupo XII - Sealapex ${ }^{\circledR}$ com LPS - 21 dias (Figura 19)}

Na reação tecidual frente ao cimento Sealapex ${ }^{\circledR}$ em associação com LPS, após 21 dias, houve a diminuição do infiltrado inflamatório e aumento do fibrosamento da cápsula. No espécime representativo deste grupo, pode-se visualizar a presença de hemorragia por rexe. Observou-se a invaginação do tecido no interior do tubo com a presença de neutrófilos e macrófagos.
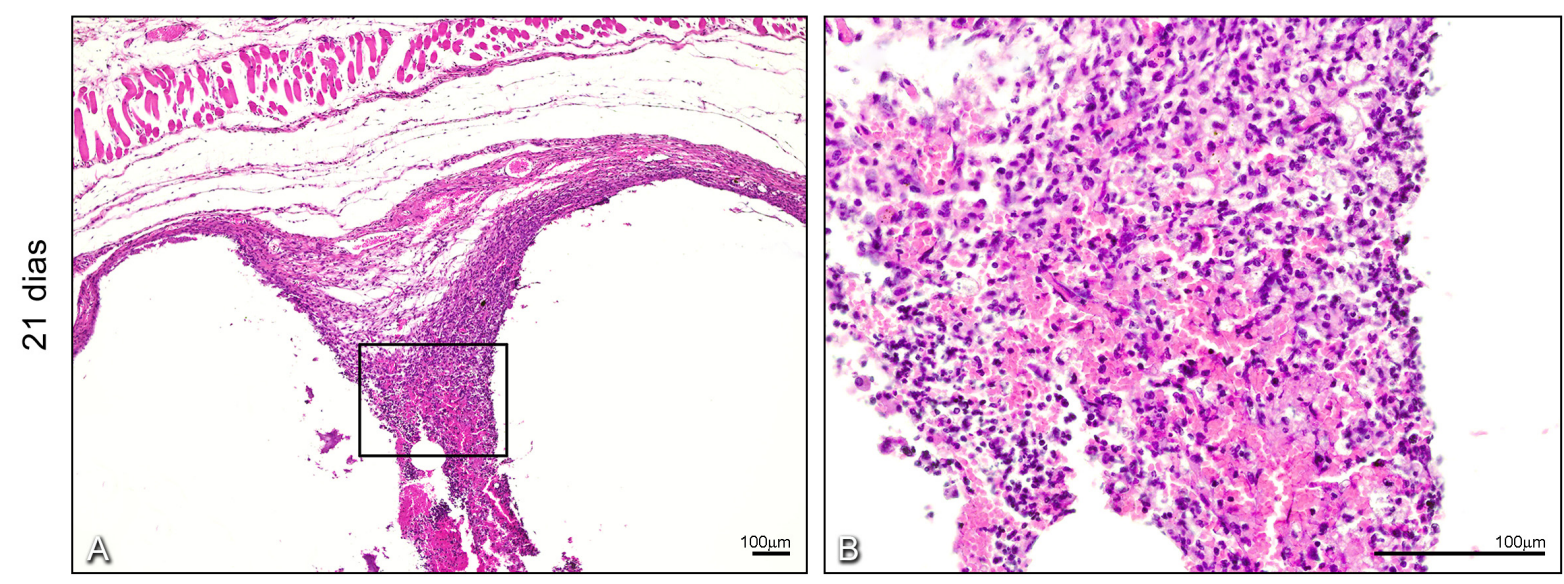

Figura 19 Grupo XII - Aspectos microscópicos da reação do tecido conjuntivo subcutâneo de camundongos frente ao implante. (A) Corte histológico corado em HE, objetiva de 4,2X; (B) área destacada da figura (A) com objetiva de 20X.

\section{Grupo XIII - Activ GP ${ }^{\circledR}$ com PBS - 21 dias (Figura 20)}

$\mathrm{Na}$ interface com o material, o tecido reacional apresentou uma melhora na organização tecidual com redução do infiltrado inflamatório e aumento do fibrosamento. Entre os fibroblastos eram visíveis neutrófilos, macrófagos.
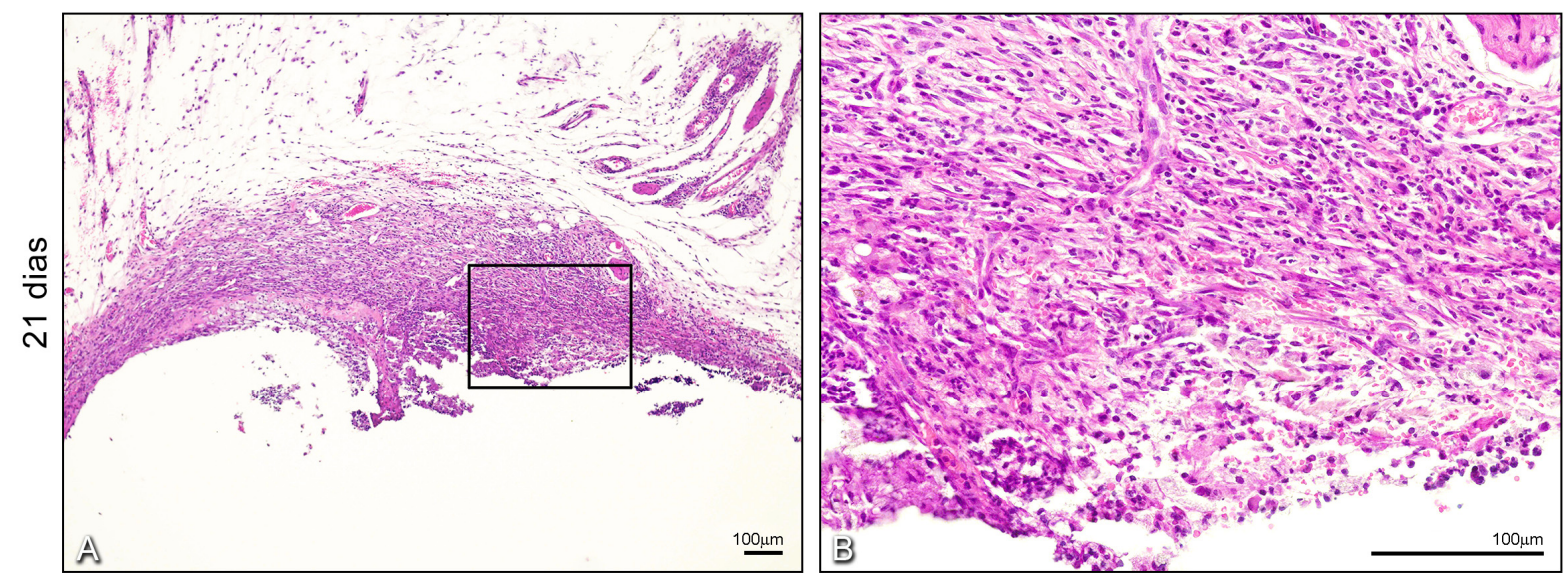

Figura 20 Grupo XIII - Aspectos microscópicos da reação do tecido conjuntivo subcutâneo de camundongos frente ao implante. (A) Corte histológico corado em HE, objetiva de 4,2X; (B) área destacada da figura (A) com objetiva de 20X. 



\section{Grupo XIV - Activ GP ${ }^{\circledR}$ com LPS - 21 dias (Figura 21)}

A espessura da resposta tecidual, aos 21 dias frente ao Activ $\mathrm{GP}^{\circledR}$, revelou-se fina com fibrosamento moderado e bem organizada, além de um pequeno infiltrado inflamatório com poucos neutrófilos e macrófagos. Também foi possível detectar a invaginação do tecido para o interior do tubo.
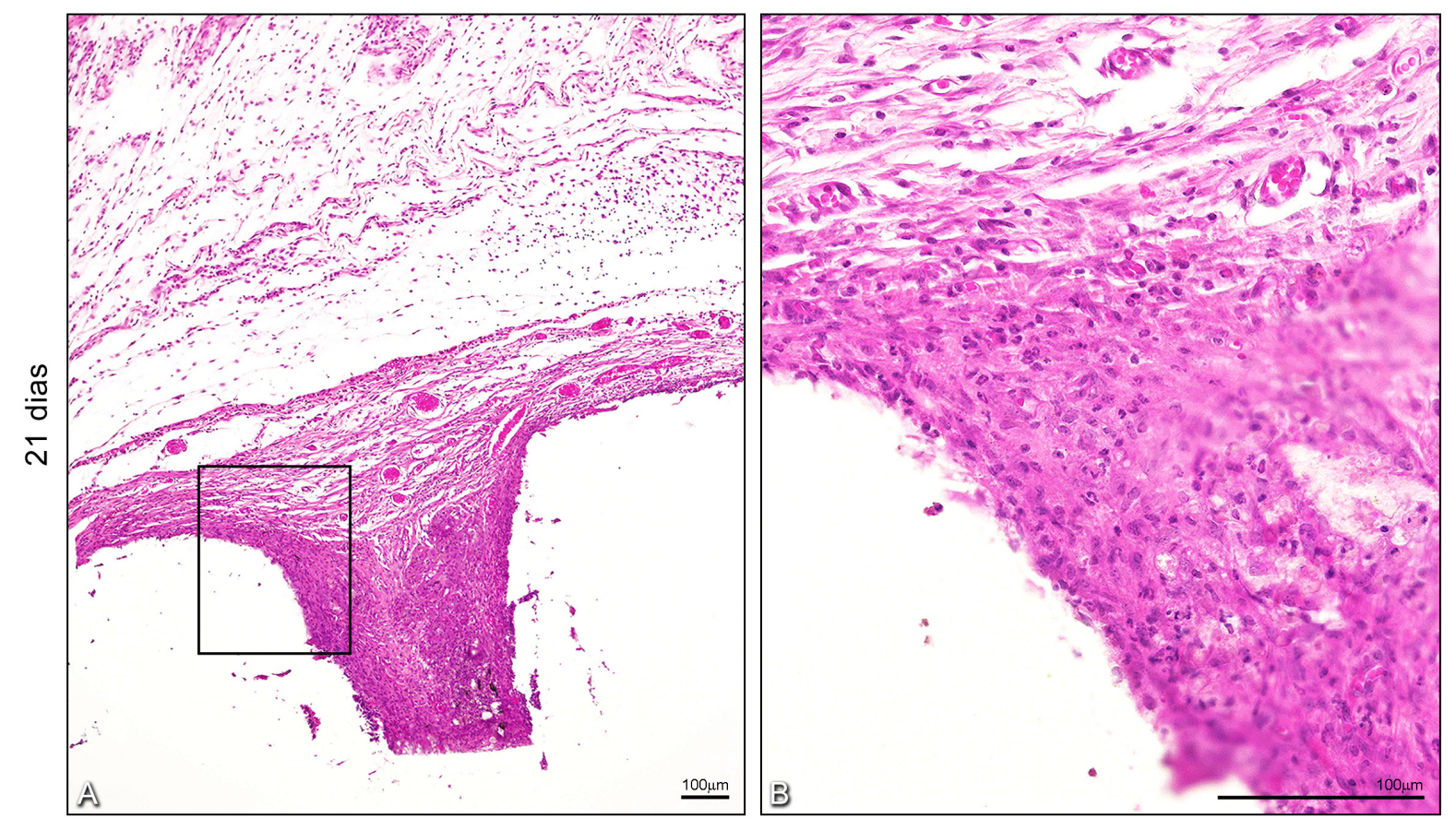

Figura 21 Grupo XIV - Aspectos microscópicos da reação do tecido conjuntivo subcutâneo de camundongos frente ao implante. (A) Corte histológico corado em HE, objetiva de 4,2X; (B) área destacada da figura (A) com objetiva de 20X. 



\section{Grupo XV-AH-P/us ${ }^{\circledR}$ com PBS - 21 dias (Figura 22)}

Este grupo teve a presença de infiltrado inflamatório moderado caracterizado pela abundância de macrófagos com o citoplasma vacuolado. Células gigantes multinucleadas e pequena incidência de neutrófilos. Houve uma maior organização do tecido e dos feixes de fibras colágenas.
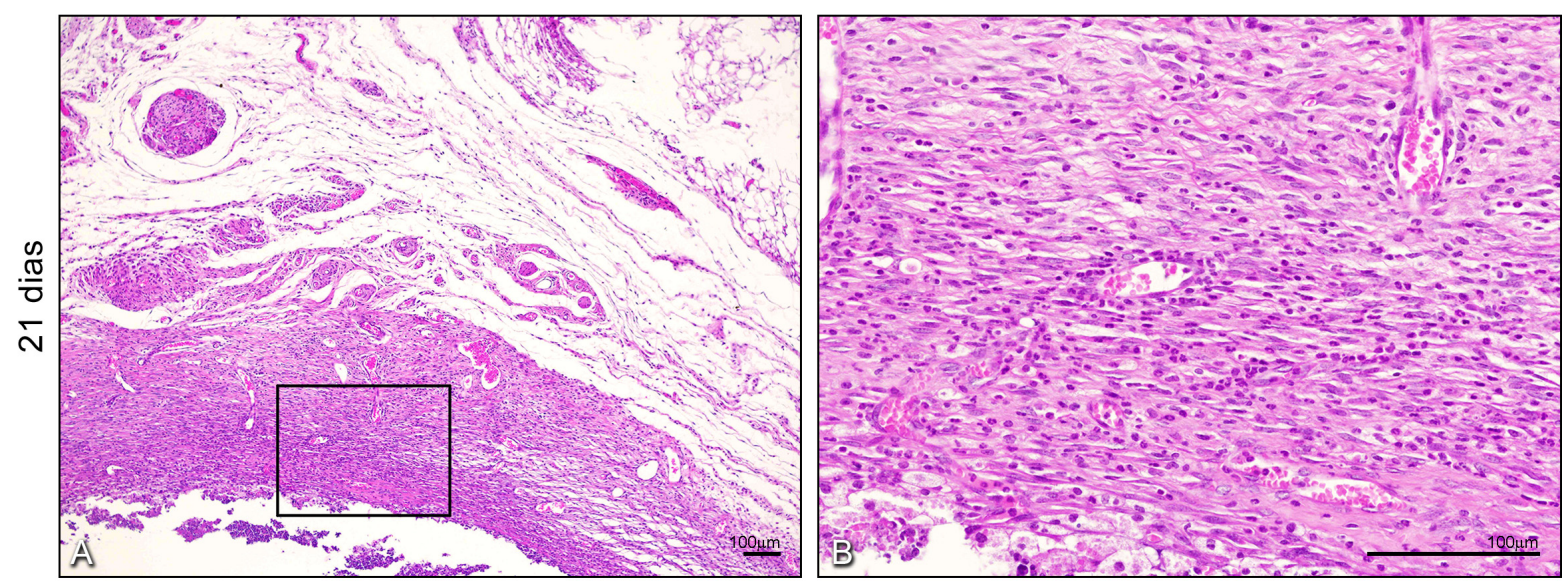

Figura 22 Grupo XV - Aspectos microscópicos da reação do tecido conjuntivo subcutâneo de camundongos frente ao implante. (A) Corte histológico corado em HE, objetiva de 4,2X; (B) área destacada da figura (A) com objetiva de $20 x$.

\section{Grupo XVI - AH-Plus ${ }^{\circledR}$ com LPS - 21 dias (Figura 23)}

Neste grupo pode-se observar a redução do infiltrado inflamatório e aumento da organização do tecido quando comparado com o período de 7 dias. No espécime representativo foi possível detectar a presença do material de permeio ao tecido e no interior do citoplasma dos macrófagos. A quantidade de neutrófilos foi bastante reduzida.
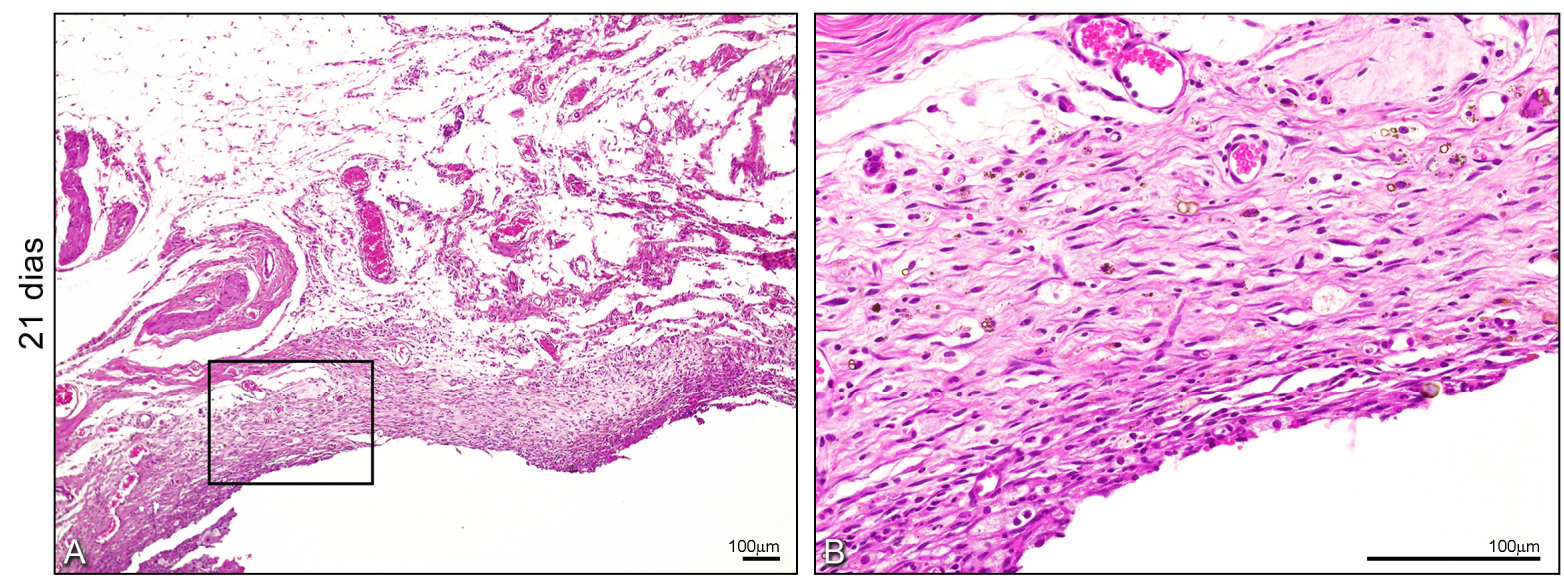

Figura 23 Grupo XVI - Aspectos microscópicos da reação do tecido conjuntivo subcutâneo de camundongos frente ao implante. (A) Corte histológico corado em HE, objetiva de 4,2X; (B) área destacada da figura (A) com objetiva de 20X. 

Com 63 dias, podemos observar o aumento da densidade das fibras colágenas que se apresentam bem organizadas em feixes paralelos. Presença de poucas células inflamatórias, neutrófilos e macrófagos de permeio ao tecido. É possível observar a redução do processo inflamatório no decorrer dos períodos experimentais.
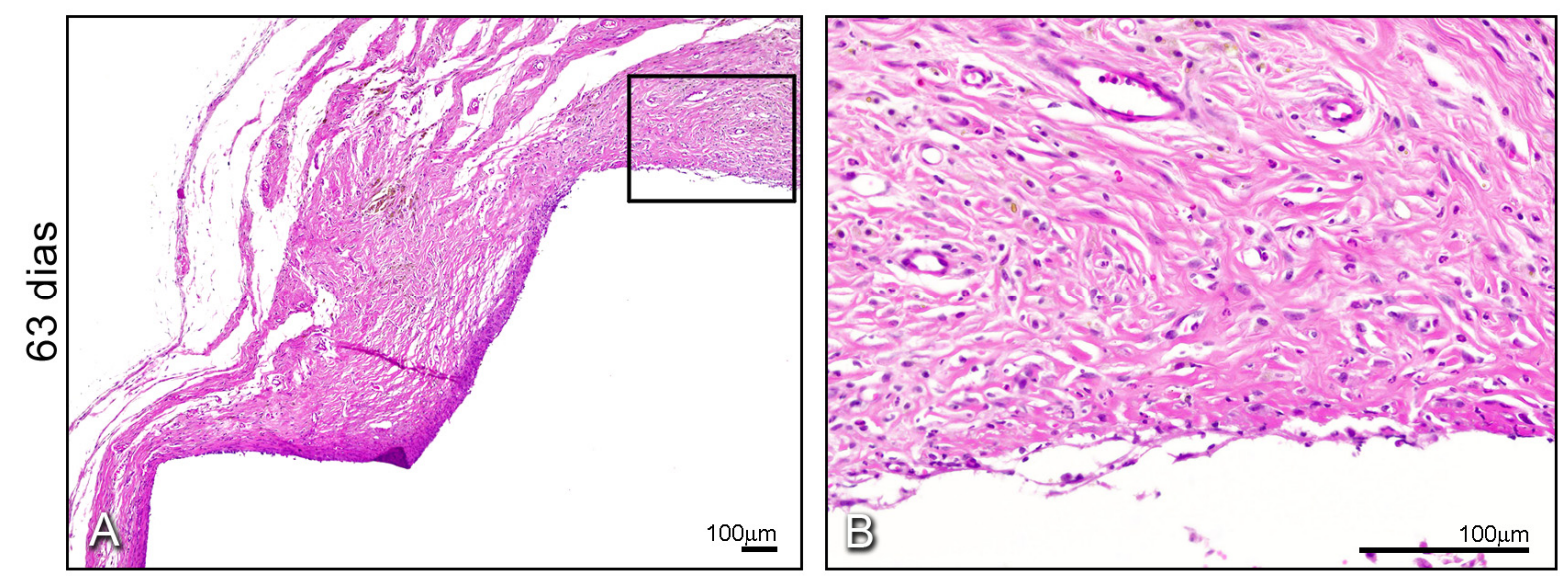

Figura 24 Grupo XVII - Aspectos microscópicos da reação do tecido conjuntivo subcutâneo de camundongos frente ao implante. (A) Corte histológico corado em HE, objetiva de 4,2X; (B) área destacada da figura (A) com objetiva de 20X.

\section{Grupo XVIII - Tubo vazio com LPS - 63 dias (Figura 25)}

Após os 63 dias, o tecido reacional aumentou seu grau de fibrosamento e diminuiu de espessura. Foi possível observar a presença de macrófagos e neutrófilos em quantidade bem inferior a apresentada aos 7 e 21 dias.
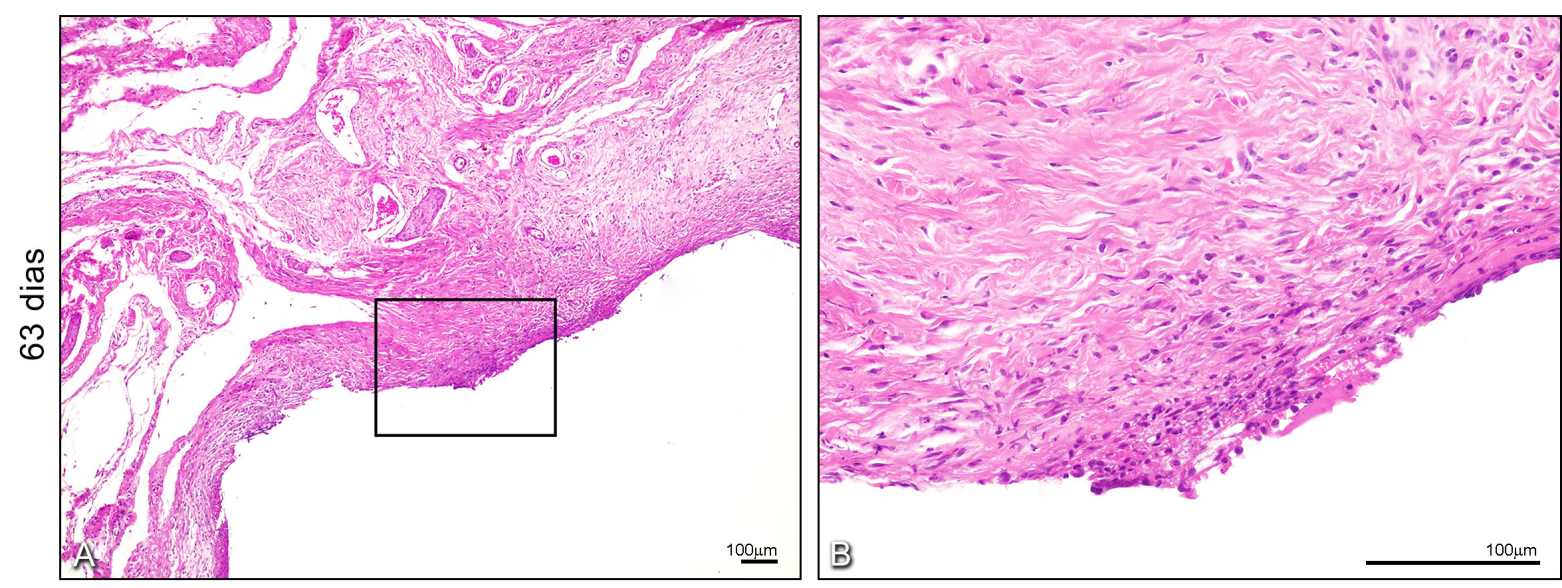

Figura 25 Grupo XVIII - Aspectos microscópicos da reação do tecido conjuntivo subcutâneo de camundongos frente ao implante. (A) Corte histológico corado em HE, objetiva de 4,2X; (B) área destacada da figura (A) com objetiva de 20X. 



\section{Grupo IXX - Sealapex ${ }^{\circledR}$ com PBS - 63 dias (Figura 26)}

Neste grupo observa-se a permanência do infiltrado inflamatório na interface do material com o tecido reacional. Pode-se visualizar o aumento da cápsula fibrosa e a presença de macrófagos, neutrófilos e células gigantes multinucleadas por entre os fibroblastos.
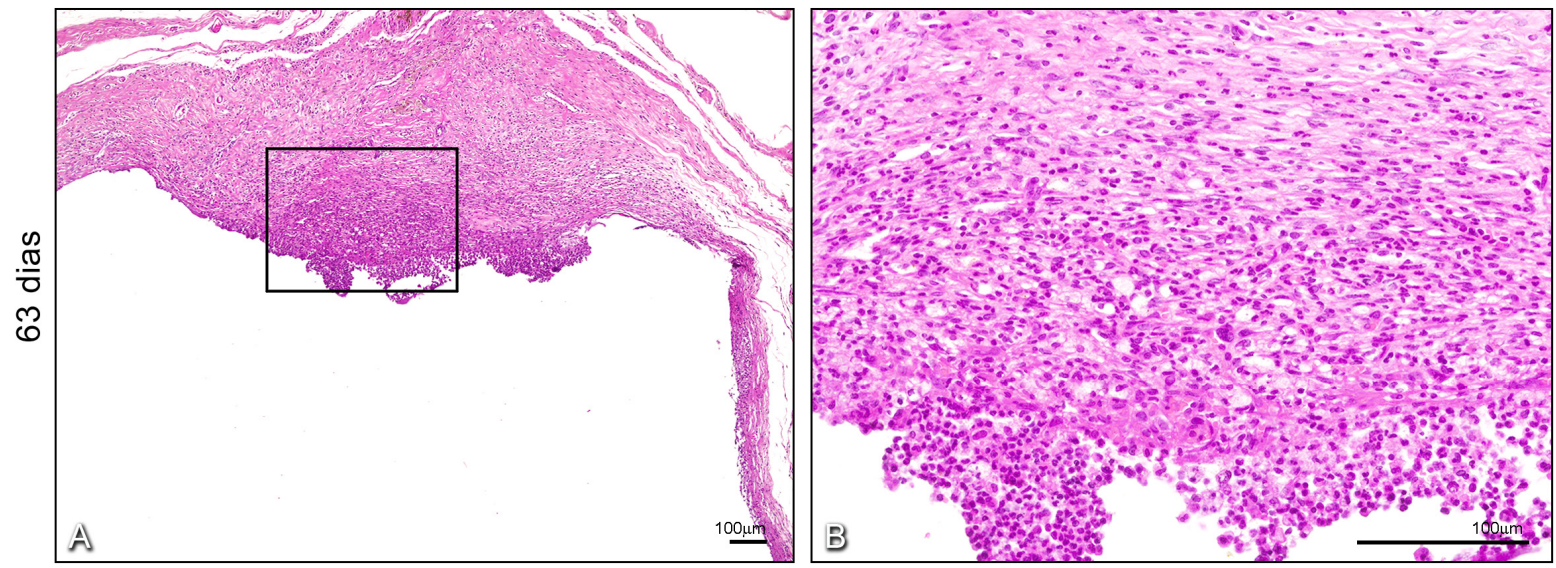

Figura 26 Grupo XIX - Aspectos microscópicos da reação do tecido conjuntivo subcutâneo de camundongos frente ao implante. (A) Corte histológico corado em HE, objetiva de 4,2X; (B) área destacada da figura (A) com objetiva de 20X.

\section{Grupo XX - Sealapex ${ }^{\circledR}$ com LPS - 63 dias (Figura 27)}

A resposta tecidual ao implante evidenciou a presença de infiltrado inflamatório com a participação de macrófagos, neutrófilos e células gigantes multinucleadas. Houve um aumento da densidade de fibras colágenas quando comparado aos outros períodos experimentais.
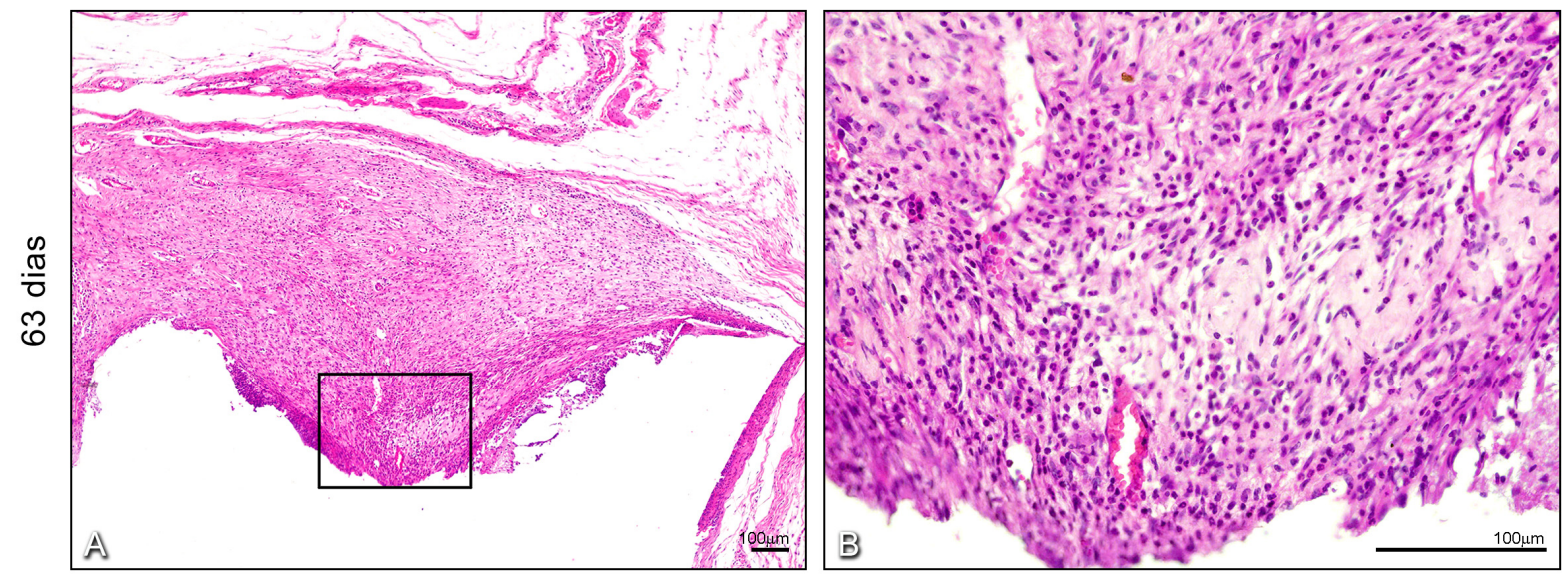

Figura 27 Grupo XX - Aspectos microscópicos da reação do tecido conjuntivo subcutâneo de camundongos frente ao implante. (A) Corte histológico corado em HE, objetiva de 4,2X; (B) área destacada da figura (A) com objetiva de 20X. 



\section{Grupo XXI - Activ GP ${ }^{\circledR}$ com PBS - 63 dias (Figura 28)}

Após 63 dias, o tecido reacional se limita a uma fina cápsula de tecido conjuntivo fibroso com as fibras colágenas densas e organizadas com a presença escassa de macrófagos por entre os fibroblastos.
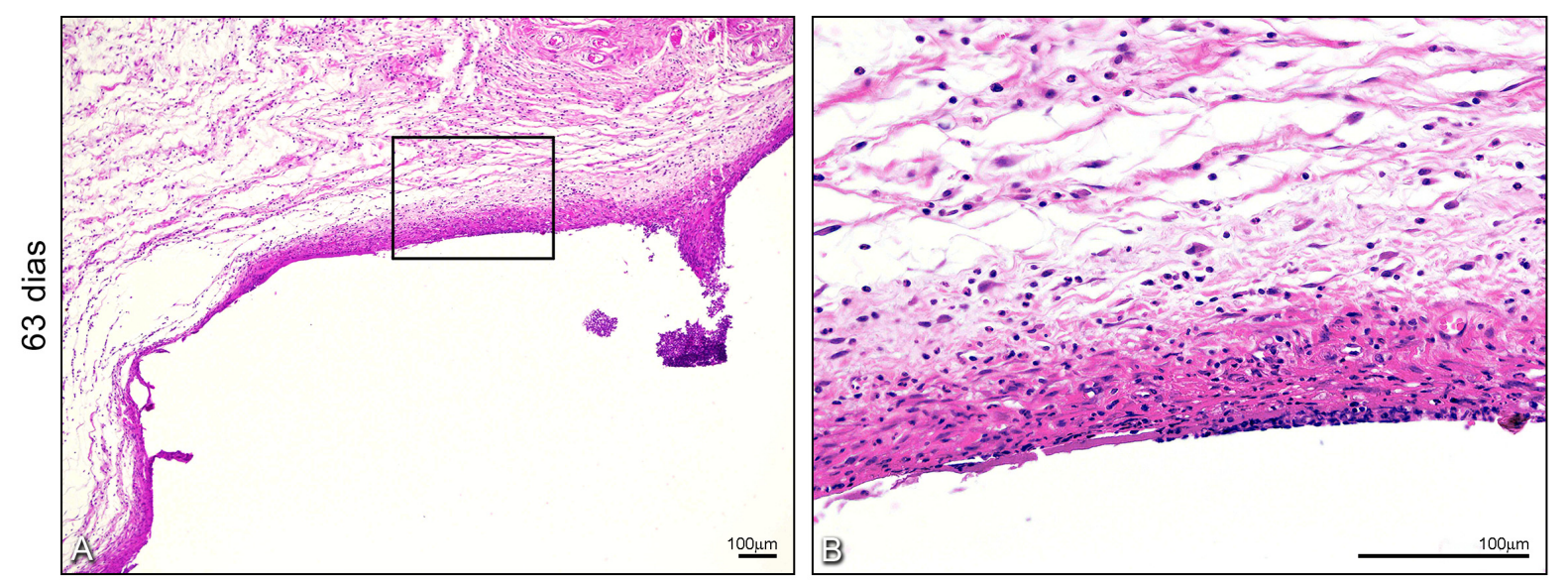

Figura 28 Grupo XXI - Aspectos microscópicos da reação do tecido conjuntivo subcutâneo de camundongos frente ao implante. (A) Corte histológico corado em HE, objetiva de 4,2X; (B) área destacada da figura (A) com objetiva de 20X.

\section{Grupo XXII - Activ GP ${ }^{\circledR}$ com LPS - 63 dias (Figura 29)}

Presença de cápsula fibrosa bem definida e organizada com fibroblastos envoltos em grande quantidade de fibras colágenas. Infiltrado inflamatório discreto com a presença de poucos macrófagos na periferia do tecido.
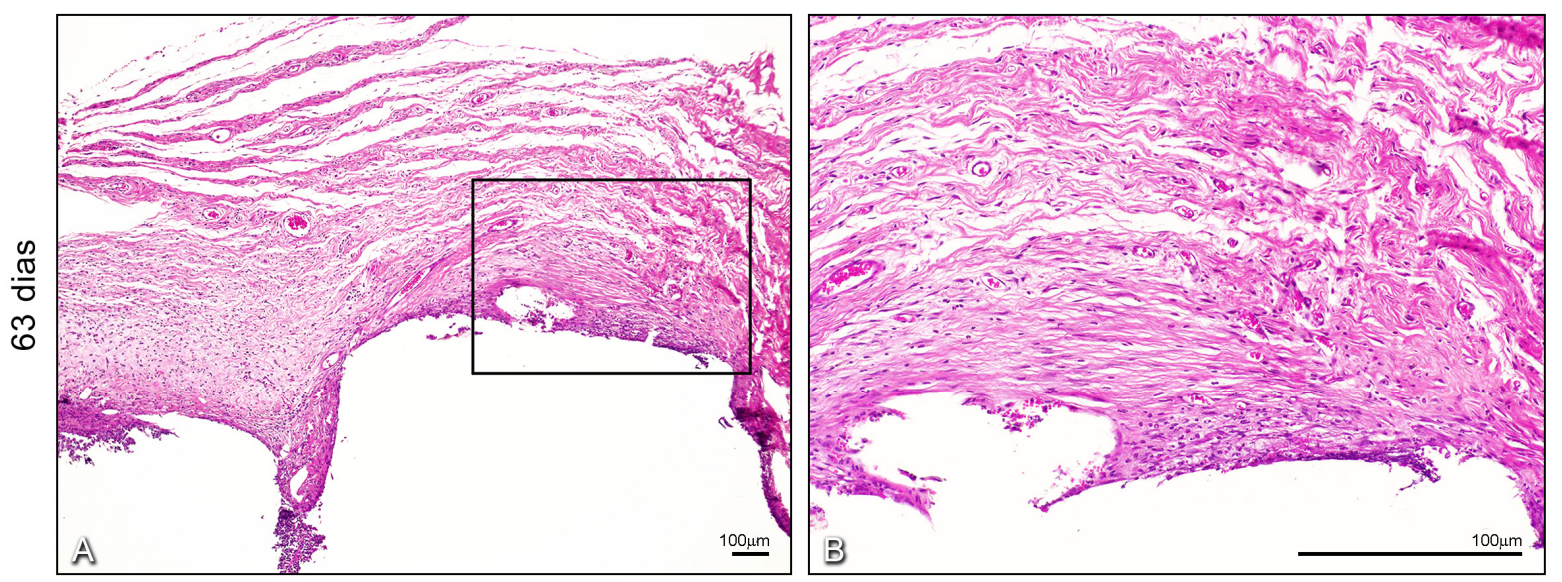

Figura 29 Grupo XXII - Aspectos microscópicos da reação do tecido conjuntivo subcutâneo de camundongos frente ao implante. (A) Corte histológico corado em HE, objetiva de 4,2X; (B) área destacada da figura (A) com objetiva de 20X. 



\section{Grupo XXIII- AH-PIus ${ }^{\circledR}$ Com PBS - 63 dias (Figura 30)}

As 63 dias as características histológicas deste grupo foram semelhantes ao descrito no período anterior (grupo XVI) não apresentando mudanças significativas com relação à capsula fibrosa e infiltrado inflamatório.
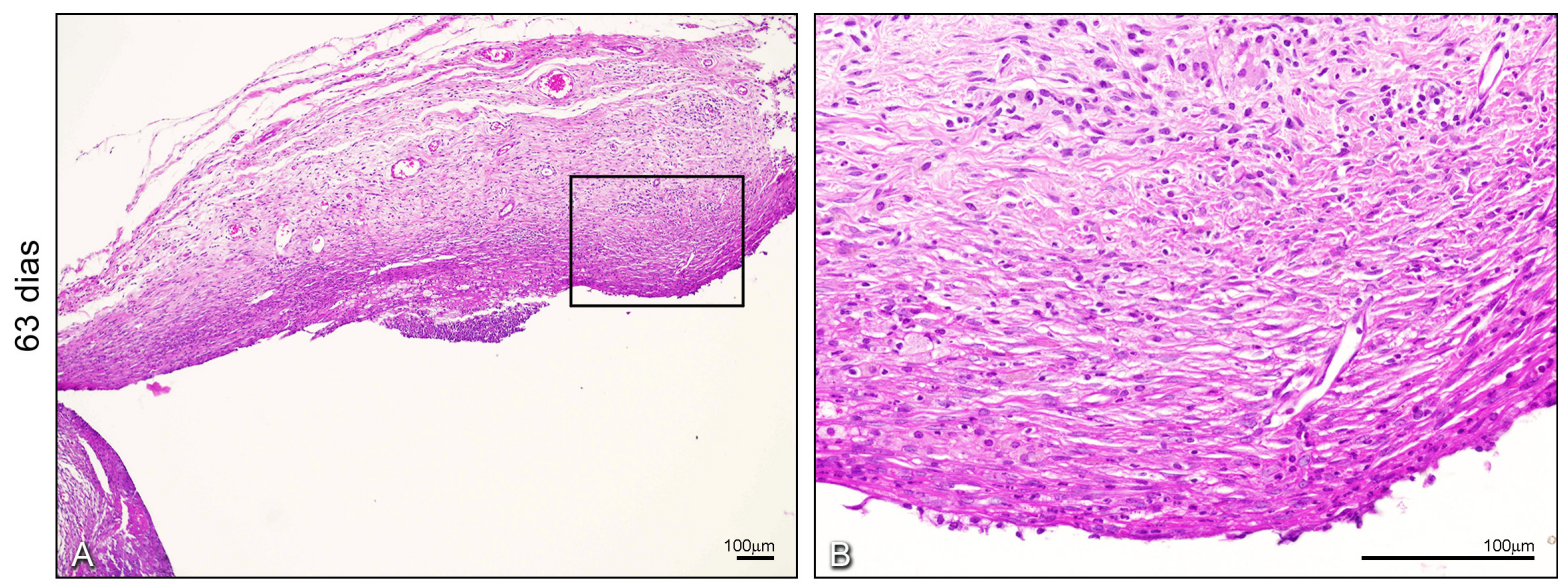

Figura 30 Grupo XXIII - Aspectos microscópicos da reação do tecido conjuntivo subcutâneo de camundongos frente ao implante. (A) Corte histológico corado em HE, objetiva de 4,2X; (B) área destacada da figura (A) com objetiva de 20X.

\section{Grupo XXIV-AH-PIus ${ }^{\circledR}$ Com LPS - 63 dias (Figura 31)}

Houve um aumento da deposição de fibras colágenas em relação aos períodos anteriores. O infiltrado inflamatório ainda estava bem evidente com a presença de macrófagos e neutrófilos.
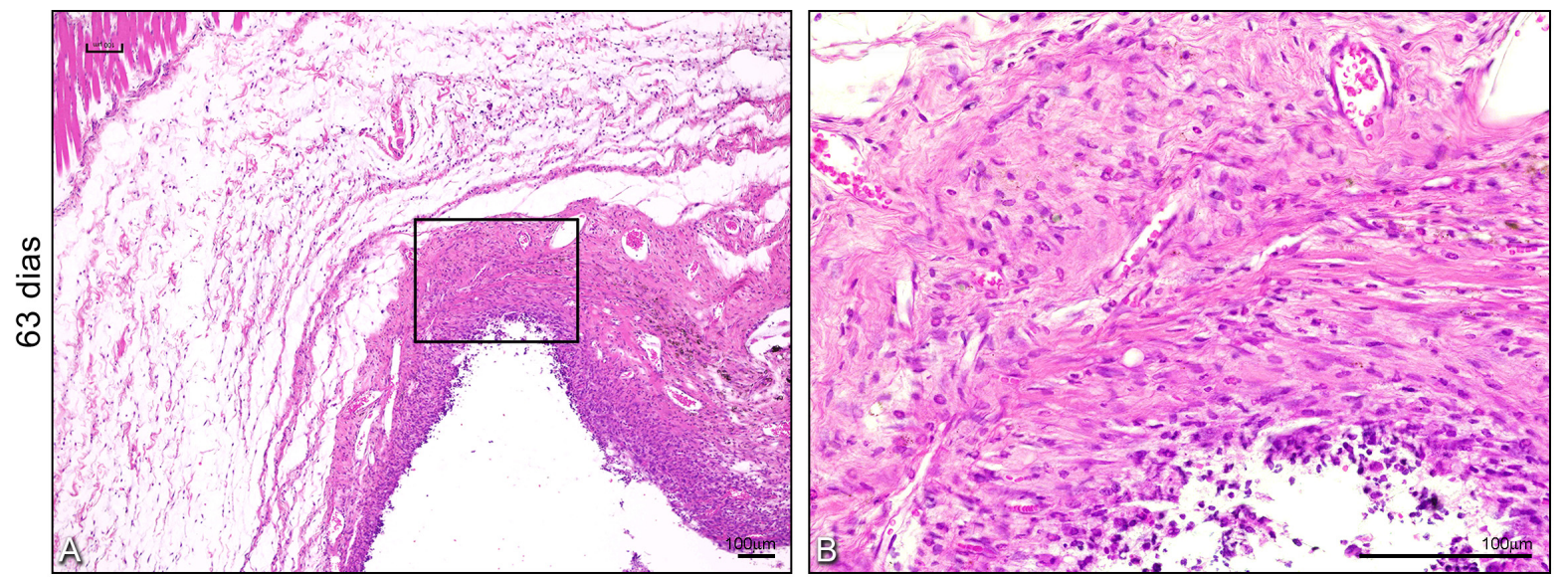

Figura 31 Grupo XIV - Aspectos microscópicos da reação do tecido conjuntivo subcutâneo de camundongos frente ao implante. (A) Corte histológico corado em HE, objetiva de 4,2X; (B) área destacada da figura (A) com objetiva de 20X. 



\subsection{Variação da produção de citocinas frente aos diferentes cimentos nos diferentes tempos experimentais - Teste CBA}

\section{IL-2}

A citocina IL-2 apresentou maiores valores para os grupos controle e Sealapex ${ }^{\circledR}$ aos 21 dias. No período de 7 dias houve diferença estatística apenas entre os grupos AH-Plus ${ }^{\circledR}$ e Activ-GP $^{\circledR}(p=0,0391)$. No período de 21 dias foram detectadas diferenças entre o grupo controle e AH-Plus ${ }^{\circledR}(p=0,0402)$ e entre o grupo Sealapex ${ }^{\circledR}$ e AH-Plus ${ }^{\circledR}(p=0,0244)$. Aos 63 dias, não houve diferença estatística entre os grupos(Figura 32).

Cinética IL-2

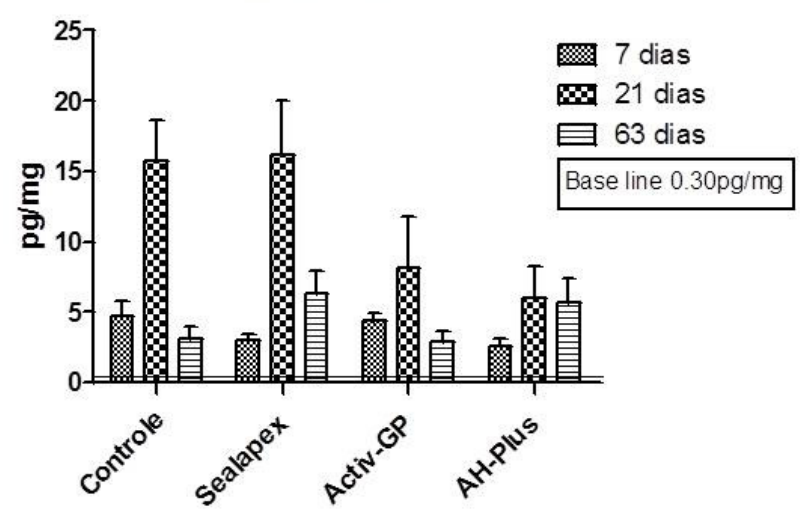

21 dias

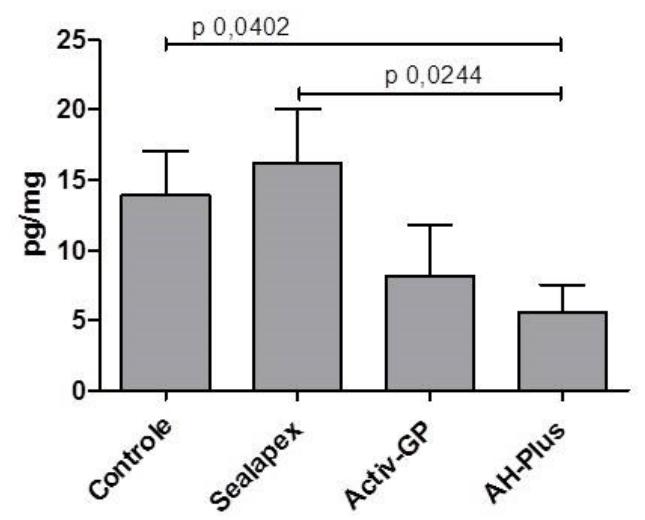

7 dias

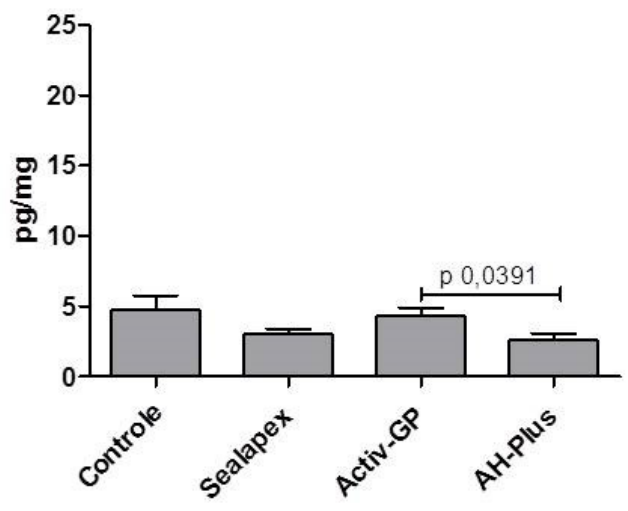

63 dias

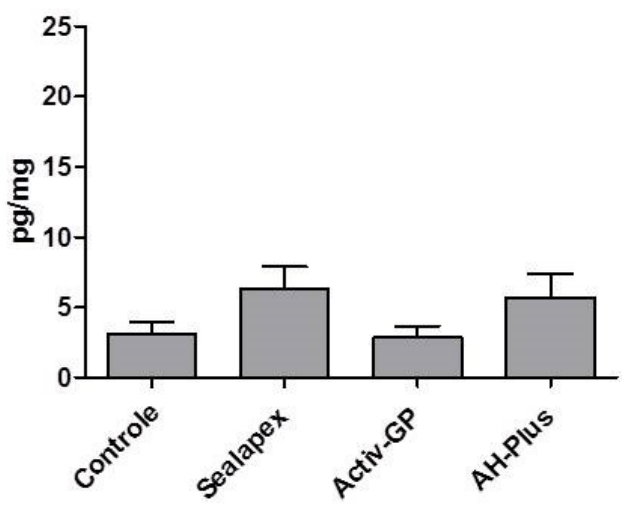

Figura 32 Média e desvio padrão da citocina IL-2, nos diferentes grupos avaliados. 


\section{IL-6}

A produção de IL-6 reduziu ao longo dos tempos experimentais. Os picos de produção foram aos 7 dias para todos os grupos. No primeiro tempo experimental (7 dias) foi detectada diferença apenas entre os grupos Activ-GP ${ }^{\circledR}$ e $A H-P l u s{ }^{\circledR}(p=0,0286)$. Com 21 dias, o cimento AH-Plus ${ }^{\circledR}$ apresentou resultados estatisticamente maiores quando comparado ao controle e Activ-GP ${ }^{\circledR}$. Após 63 não foram detectadas diferenças entre os grupos (Figura 33).

\section{Cinética IL-6}

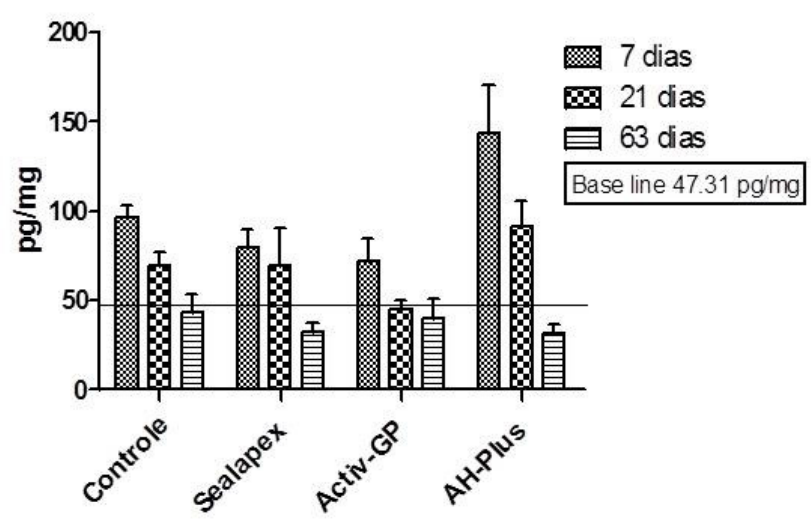

21 dias

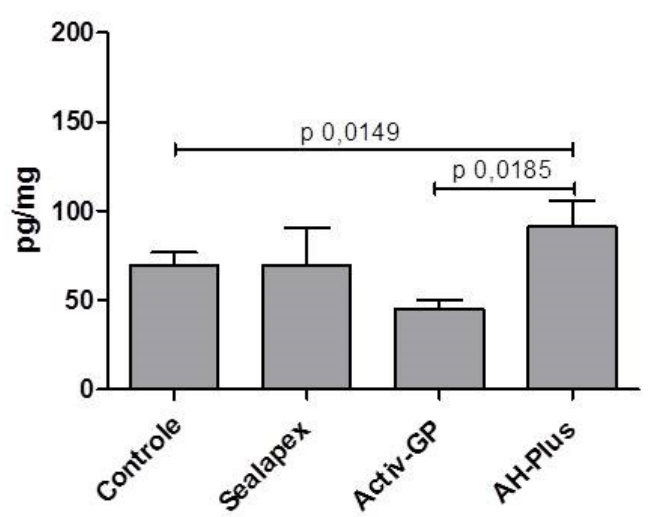

7 dias

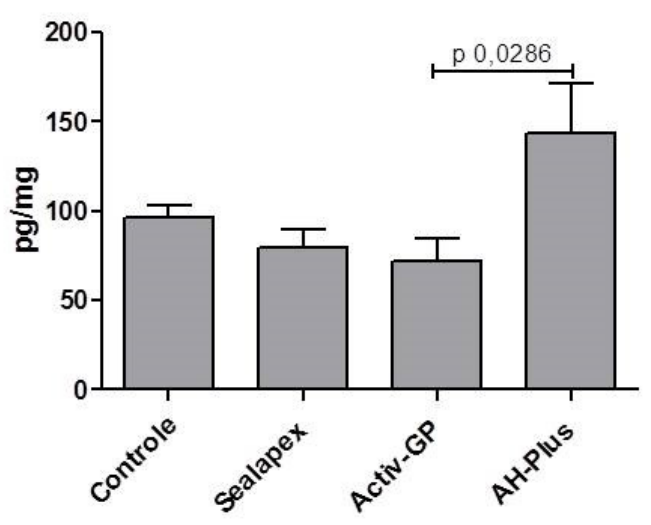

63 dias

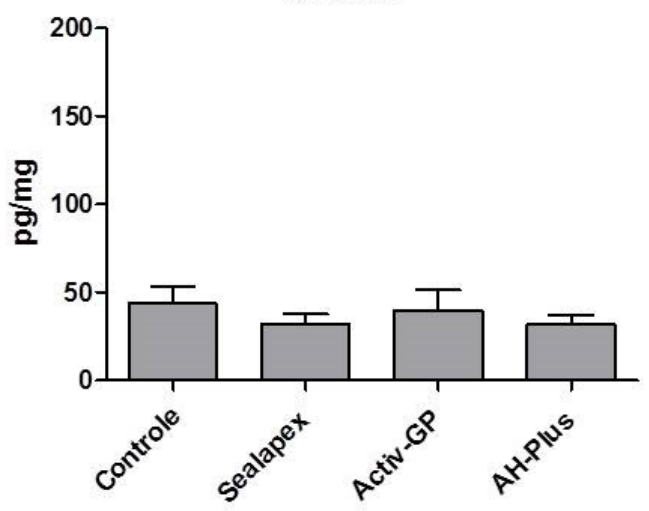

Figura 33 Média e desvio padrão da citocina IL-6, nos diferentes grupos avaliados. 


\section{TNF-c}

O TNF-a apresentou declínio de sua concentração ao longo dos períodos experimentais. O cimento $\mathrm{AH}-\mathrm{Plus}{ }^{\circledR}$ estimulou a liberação de quantidades maiores de TNF-a quando comparado ao grupo controle, Sealapex ${ }^{\circledR}$ e Activ-GP ${ }^{\circledR}$. Os demais grupos não apresentaram diferenças entre si. No tempos 21 e 63 dias não foram detectadas diferenças (Figura 34).
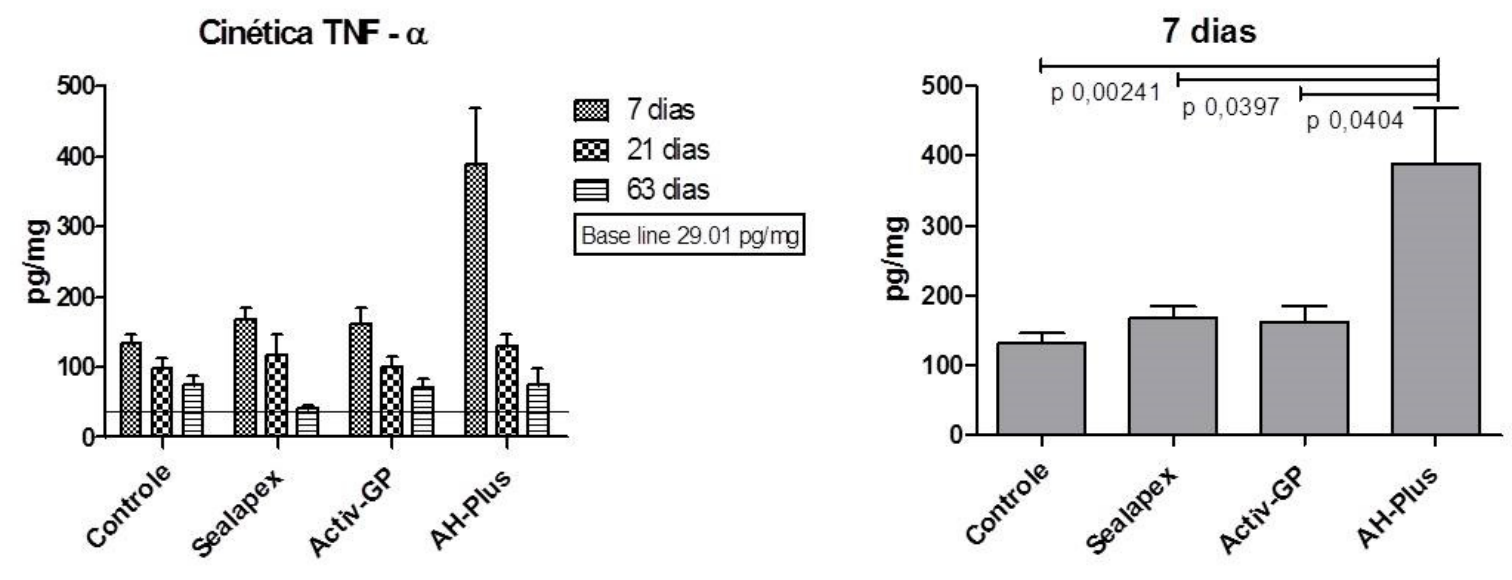

21 dias

63 dias
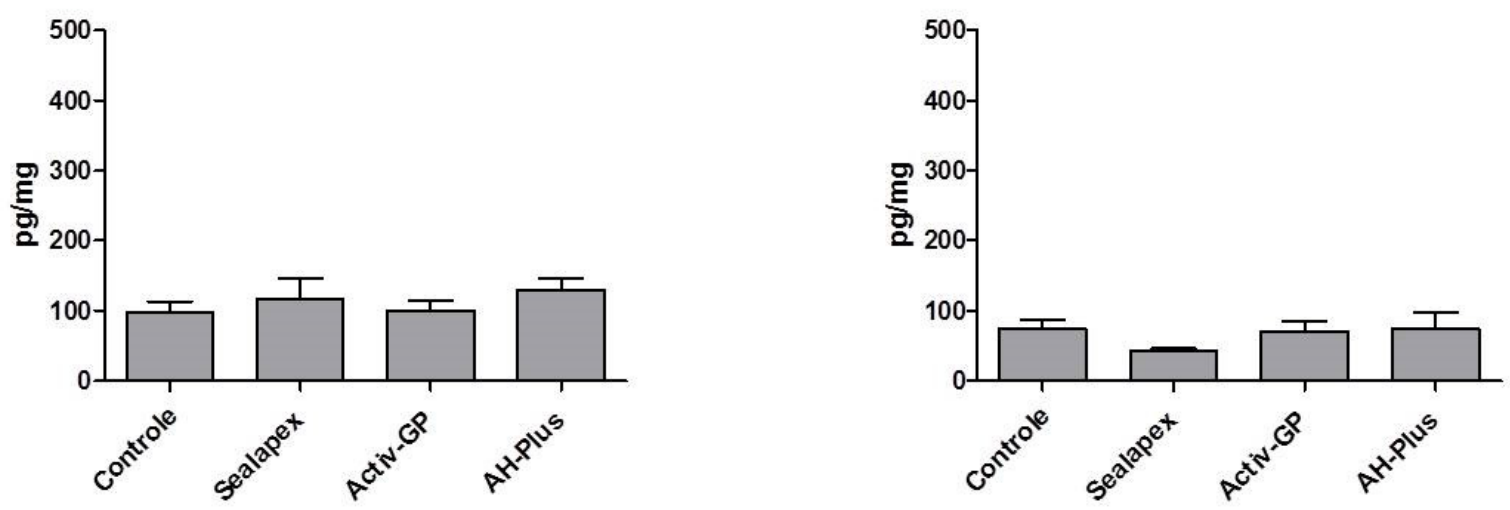

Figura 34 Média e desvio padrão da citocina TNF-a, nos diferentes grupos avaliados. 


\section{IFN-gamma}

Para os grupos controle e Sealapex ${ }^{\circledR}$ houve um pico de liberação de IFN-· com 21 dias e para os grupos Activ-GP ${ }^{\circledR}$ e AH-Plus ${ }^{\circledR}$ o pico foi aos 7 dias. Quando avaliado o período de 7 dias, apenas o grupo controle e Sealapex ${ }^{\circledR}$ apresentaram diferença $(p=0,0007)$. Aos 21 dias, os maiores valores foram encontrados para o grupo controle seguido por Sealapex ${ }^{\circledR}$,

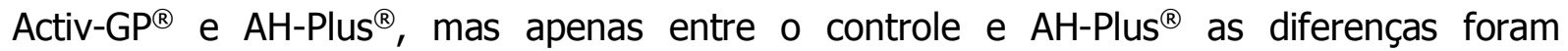
significantes ( $p=0,0193)$. Não houve diferença aos 63 dias (Figura 35).

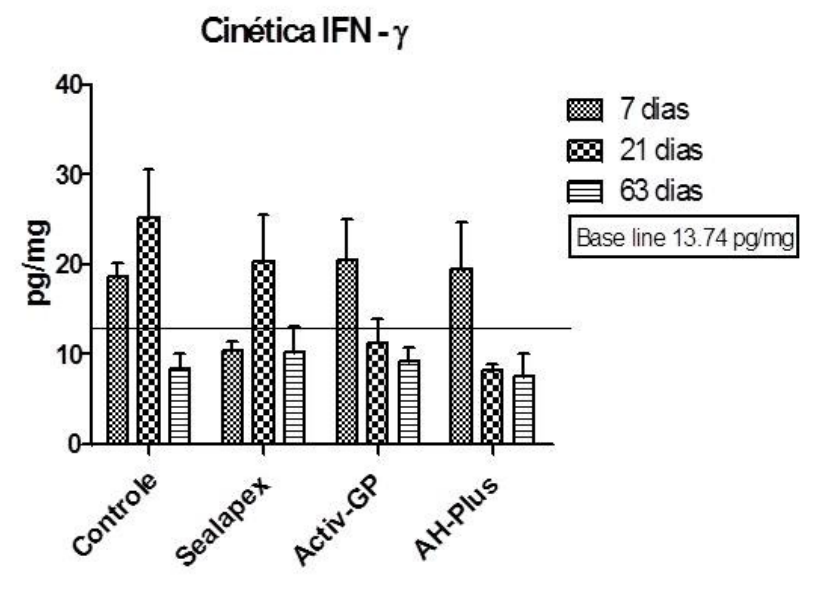

21 dias

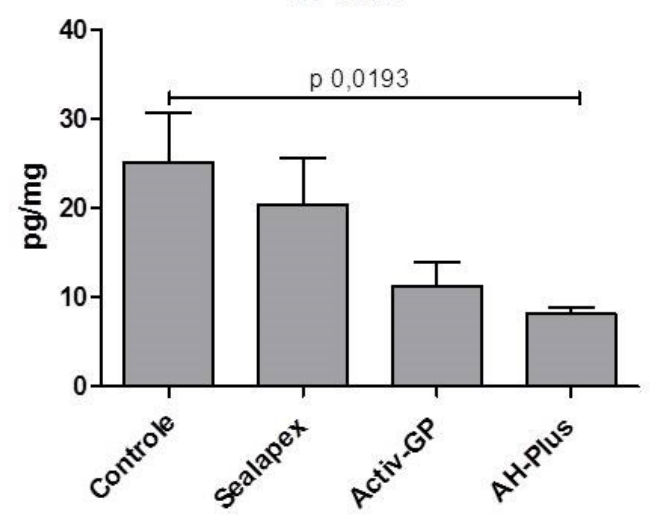

7 dias

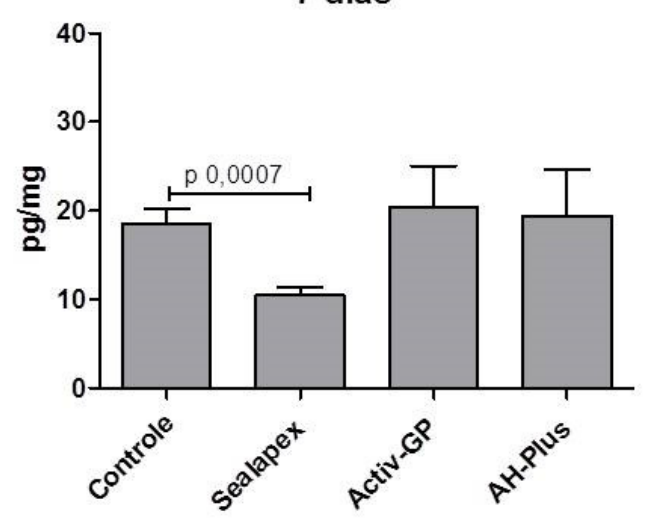

63 dias

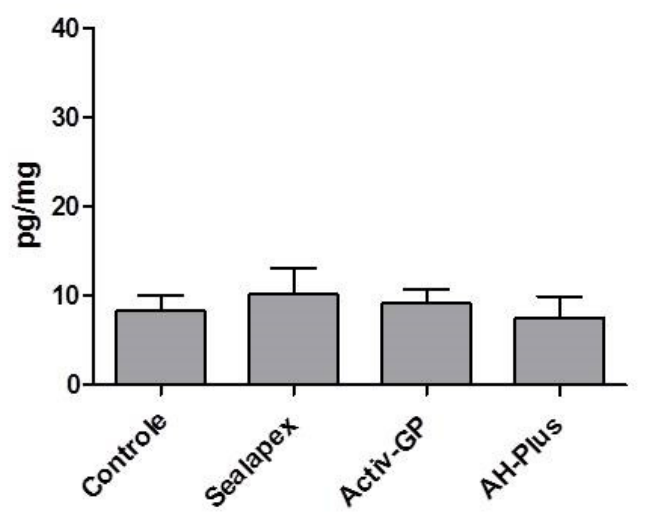

Figura 35 Média e desvio padrão da citocina IFN-Y, nos diferentes grupos avaliados. 
O nível de detecção da IL-4 foi muito baixo e por isso não foi possível realizar as análise estatísticas ente os grupos controle e Activ-GP ${ }^{\circledR}$, controle e AH-Plus ${ }^{\circledR}$, Sealapex ${ }^{\circledR}$ e Activ-GP ${ }^{\circledR}$, Sealapex ${ }^{\circledR}$ e AH-Plus ${ }^{\circledR}$ e Activ-GP ${ }^{\circledR}$ e AH-Plus ${ }^{\circledR}$ no período de 7 dias. Entre o grupo controle e Sealapex ${ }^{\circledR}$ a diferença foi detectada com $p=0,0158$. Nos demais períodos, não houveram diferenças (Figura 36).

Cinética IL-4

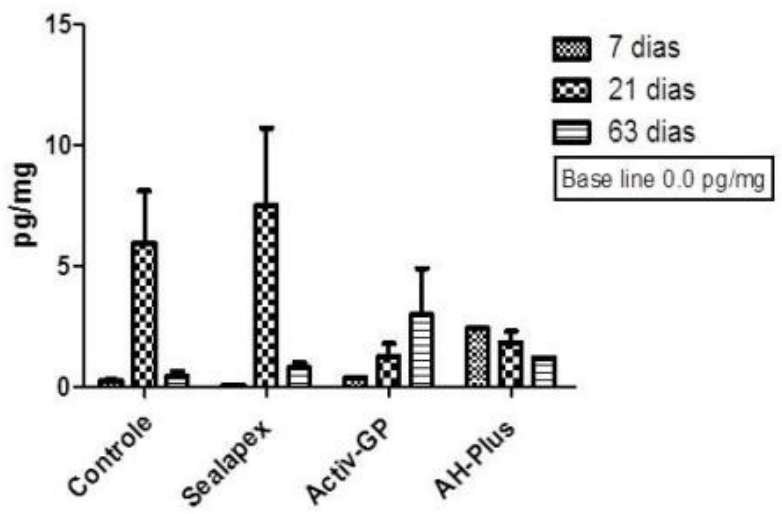

21 dias

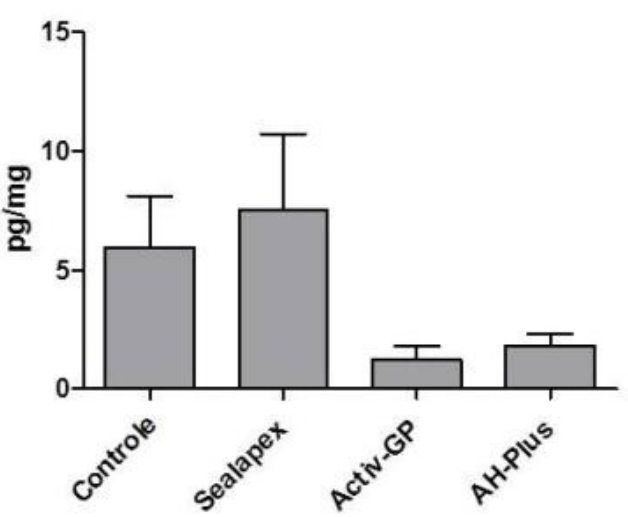

7 dias

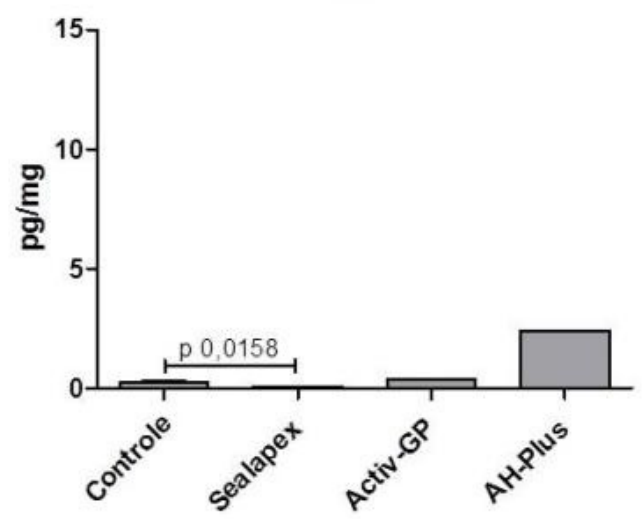

63 dias

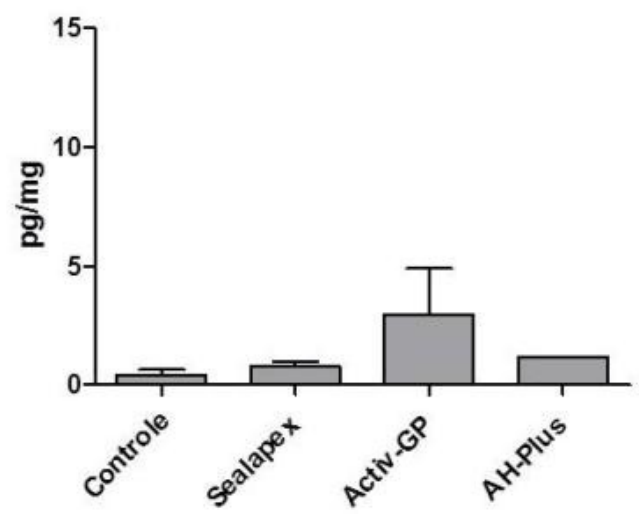

Figura 36 Média e desvio padrão da citocina IL-4, nos diferentes grupos avaliados. 


\section{IL-10}

Todos os grupos apresentaram picos de produção aos 21 dias. Os valores com 7 e 63 dias não apresentaram diferenças estatisticamente significantes. Apenas o grupo controle e Activ GP ${ }^{\circledR}$ apresentaram diferenças significantes aos 21 dias $(p=0,0471)$ (Figura 37).

Cinética IL-10

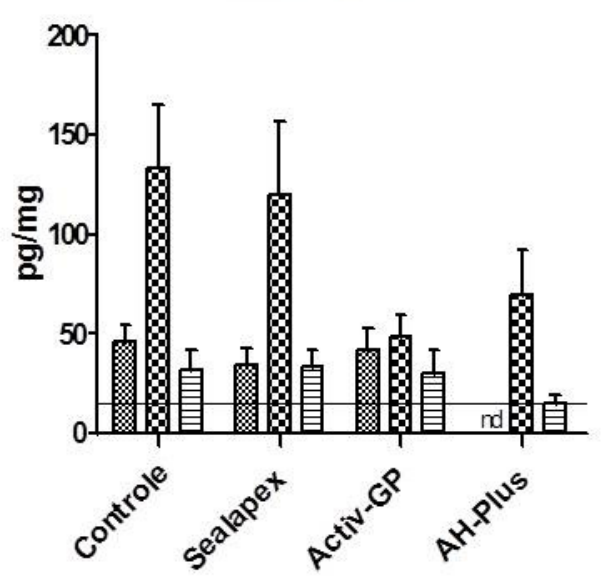

21 dias

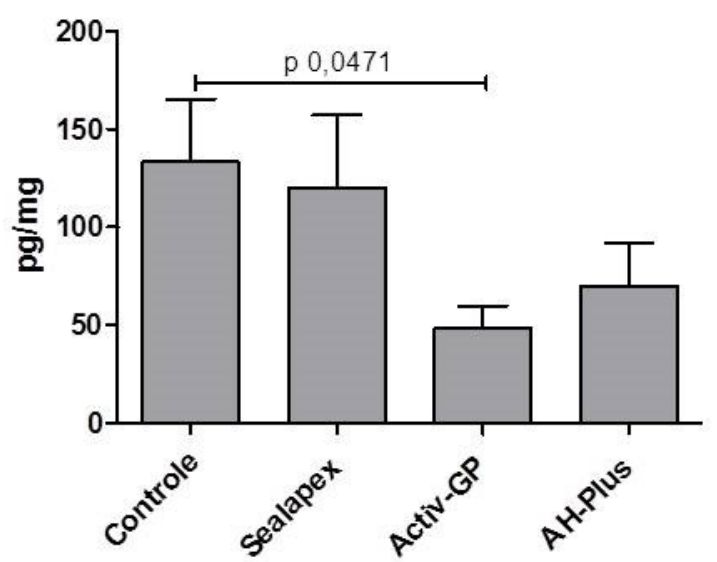

7 dias

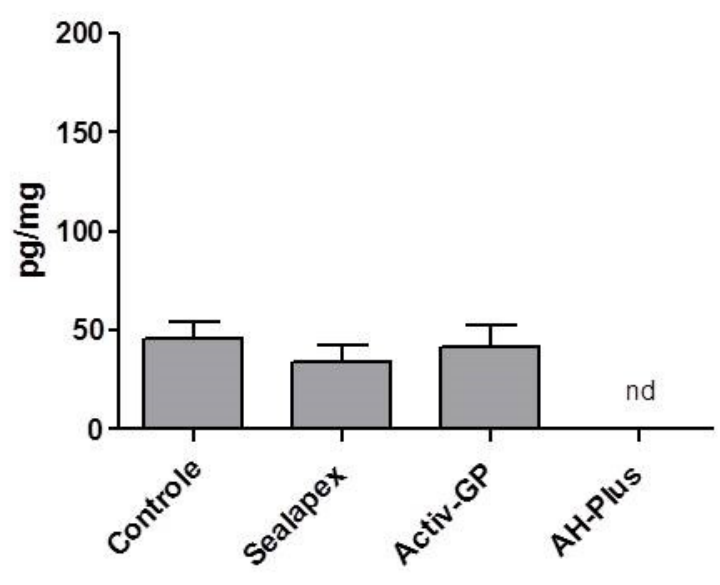

63 dias

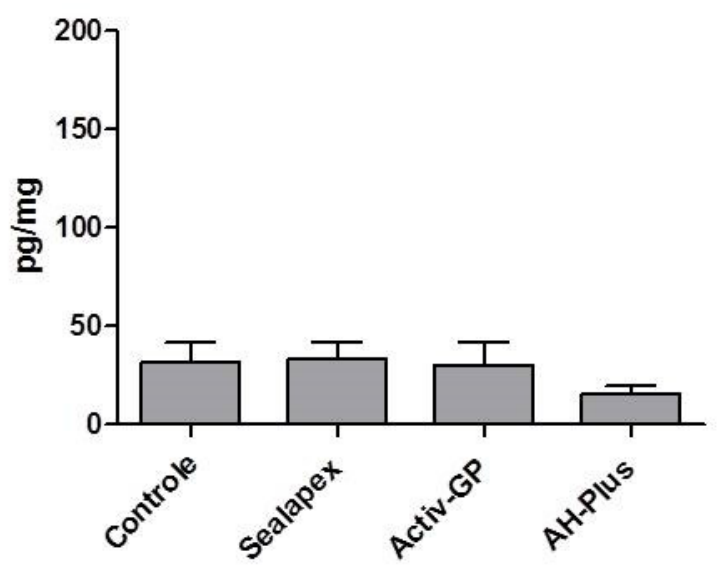

Figura 37 Média e desvio padrão da citocina IL-10, nos diferentes grupos avaliados. 


\section{IL-17}

Não houveram diferenças estatísticas entre os grupos nos períodos de 7 e 63 dias. No período de 21 dias, observou-se os maiores valores para o grupo controle seguido pelo Sealape ${ }^{\circledR}$, Activ-GP ${ }^{\circledR}$ e AH-Plus ${ }^{\circledR}$. Foram detectadas diferenças entre os grupos Controle e AH-Plus $^{\circledR}(p=0,0121)$, Controle e Activ-GP ${ }^{\circledR}(p=0,0262)$ e entre Sealapex ${ }^{\circledR}$ e Activ $G P^{\circledR}$ $(p=0,0314)$ (Figura 38).

Cinética IL-17

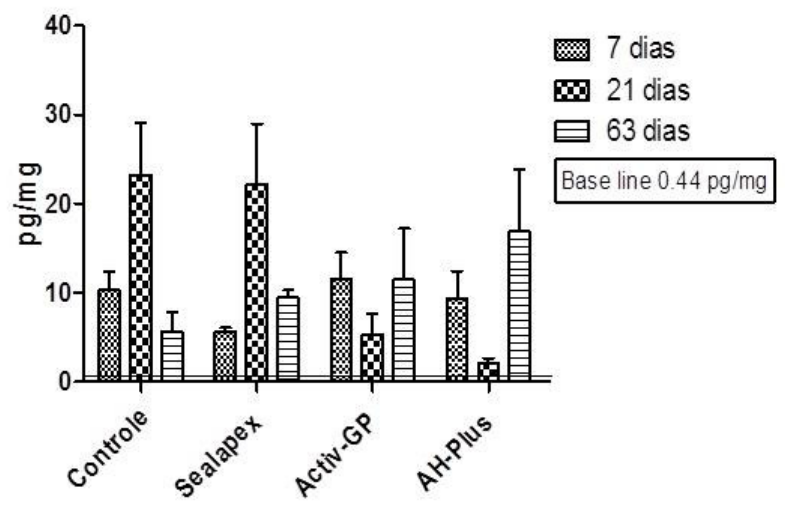

21 dias

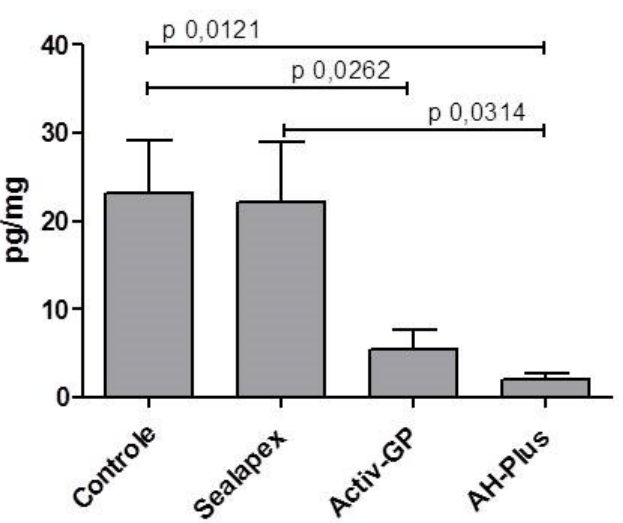

7 dias

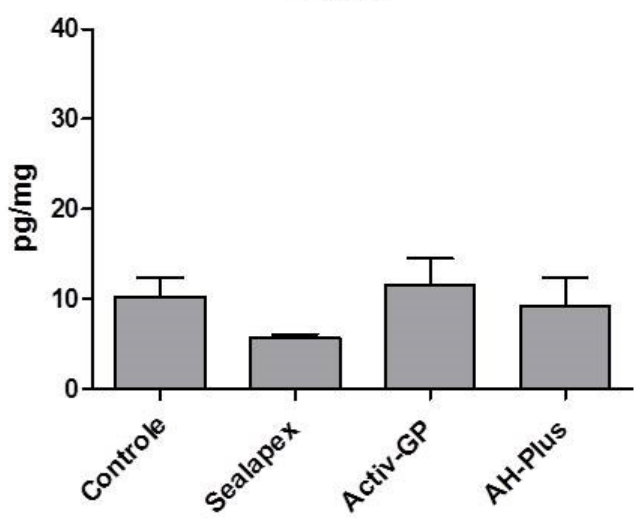

63 dias

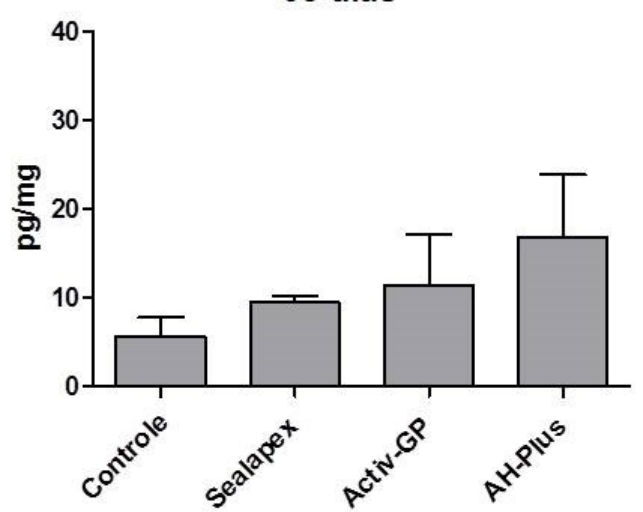

Figura 38 Média e desvio padrão da citocina IL-17, nos diferentes grupos avaliados. 

$D_{\text {iscussão }}$ 



\section{DISCUSSÃo}

\subsection{Metodologia}

Para avaliar a biocompatibilidade de cimentos endodônticos, optou-se pelo método "teste de implantação subcutânea", utilizados para avaliar a resposta biológica do tecido frente ao material implantado. Este modelo experimental, idealizado por Torneck et al. (1966), é clássico e já foi desccrito pela ISO 10993-6 (2007) sendo utilizado em inúmeros trabalhos (Valera, Leonardo et al., 2004; Farhad, Hasheminia et al., 2011; Khashaba, Moussa et al., 2011; Silva-Herzog, Ramirez et al., 2011; Silveira, Pinto et al., 2011)

Segundo Olsson et al. (1981) e Ozbas et al. (2003) as reações inflamatórias possuem as mesmas características em todos os tecidos conjuntivos, não sofrendo variação em função de sua localização. Para a avaliação da reação tecidual a cimentos endodônticos existem diversas técnicas com difetentes locais para a colocação do material, como a injeção direta nos tecidos (Figueiredo, Pesce et al., 2001; Silva-Herzog, Ramirez et al., 2011), implantes de copos de teflon em contato direto como o tecido ósseo de cobaias (Sousa, Loyola et al., 2004; Sousa, Montes et al., 2006) e a utilização de recipientes onde o material é acondicionado e implantado no tecido subcutâneo (De Oliveira, Oliveira Filho et al., 2010; Yamanaka, Shigetani et al., 2011). Na execução deste estudo, utilizou-se tubos de cloreto de polivinila (PVC) provinientes de sonda nasogástrica por estes serem atóxicos, apirogênicos, estéreis e de fácil aquisição.

O deslocamento dos tubos no interior do tecido, é um dos fatores que devem ser considerados, pois a movimentação destes poderia gerar resposta inflamatória, retardar o processo de reparo, contato entre os implantes, ou até a expulsão dos mesmos (Maurício, Comelli Lia et al., 1986). A formação de uma cápsula de tecido conjuntivo fibroso nas paredes laterais do implante, sem a presença de infiltrado inflamatório é considerado por Torneck et al. (1966) uma evidência de que não ocorreu o deslocamento dos tubos. Nossos achados corroboram com esta afirmação, onde foi possível detectar a cápsula fibrosa em todos os grupos do estudo, validando a aplicabilidade desse modelo.

Outro fator a ser avaliado é a forma de inserção dos implantes no tecido subcutâneo. Esta pode ser realizada através de um aplicador (Bortoluzzi, 2005) ou ser levado diretamente a loja cirúrgica com o auxílio de uma pinça clínica (De Oliveira, Oliveira Filho et al., 2010; Queiroz, Assed et al., 2011; Yamanaka, Shigetani et al., 2011). Segundo Moraes (2005), a utilização da pinça pode ocasionar a compressão do tubo durante a sua inserção causando o extravazamento do cimento endodôntico, invibializando a amostra. Outra 
desvantagem em relação ao uso da pinça é a dificuldade em se padronizar a posição do tubo em relação a incisão. Com a utilização do aplicador, confeccionado para a realização deste estudo, foi possível padronizar a profundidade de inserção do implante em relação a incisão, minimizando-se o contato manual com o mesmo e diminuindo as chances de contaminação. O material pôde ser depositado sem que ocorresse o contato com as paredes e bordas da loja cirúrgica confeccionada.

De acordo com a ISO 10993-6(2007) animais de pequeno porte são os mais indicados para este tipo de avaliação, podendo ser: ratos(Valera, Leonardo et al., 2004; Veloso, Do Santos et al., 2006; Farhad, Hasheminia et al., 2011; Silva-Herzog, Ramirez et al., 2011; Silveira, Pinto et al., 2011), porquinho da Índia (Sousa, Montes et al., 2006) ou camundongos(Bilginer, Esener et al., 1997; Silva, Leonardo et al., 1997; Queiroz, Assed et al., 2011). Os camundongos utilizados neste estudo foram do tipo isogênico, linhagem C57BL/6, machos. Os animais escolhidos apresentam o mesmo padrão genético e consequentemente a mesma resposta frente aos materiais testados, sendo possível implantar apenas um material em cada animal e efetuar as comparações entre eles. A escolha destes animais também foi influenciada pela possibilidade de se trabalhar em pesquisas futuras com linhagens knockout. Preferiu-se a utilização de animais machos para que não ocorressem variações hormonais durante o período experimental. 0 tamanho dos camundongos facilita o seu manejo e permite que animais pertencentes ao mesmo grupo fiquem alojados na mesma caixa, recebendo desta forma a mesma nutrição e não sofrendo variações ambientais. A área escolhida para a colocação dos implantes foi a parte dorsal do animal, por ser uma região em que a movimentação do animal pouco interfere no risco de expulsão dos implantes.

Os tempos adotados neste trabalho foram de sete, vinte e um e sessenta e três dias, de acordo com a ISO 10993-6 (2007) que define os tempos para os testes de implantação de materiais não degradáveis e não reabsorvíveis em tecido subcutâneo de camundongos nos períodos de uma a doze semanas.

\subsubsection{Da utlização do LPS}

Inumeros trabalhos demonstram que o LPS é um impotante antígeno na formação e manutenção das lesões periapicais (Fouad e Acosta, 2001; Nelson-Filho, Leonardo et al., 2002; Silva, Nelson-Filho et al., 2002; Hong, Lin et al., 2004; Leonardo, Silva et al., 2004; Da Silva, Da Silva et al., 2008). Ele é capaz de ativar macrófagos neutrófilos e fibroblastos, 
liberando uma grande variedade de citocinas (Takahashi, 1998; Matsushita, Tajima et al., 1999).

Com o intuito de criar um processo inflamatório semelhante ao que ocorre na região periapical optou-se por implantar juntamente com o cimento o LPS bacteriano, para desta forma mostrar não apenas a resposta biológica do tecido frente aos materiais testados mas também o seu comportamento frente a um processo inflamatório.

Segundo Sant'anna, Spolidorio et al. (2008), os efeitos tóxicos da endotoxina são dose-depentete e apresentam reações diferentes em função da concentração. Neste estudo utilizou-se o LPS de Escherichia coli (Serotype 055:B5 Sigma - Aldrich Sigma Chemical CO. St. Louis, MO, USA) na concentração de $10 \mathrm{mg} / \mathrm{ml}$ por ser um modelo já utilizado em diversos trabalhos na literatura (Dwyer e Torabinejad, 1981; Nelson-Filho, Leonardo et al., 2002; Da Silva, Da Silva et al., 2008; Sant'anna, Spolidorio et al., 2008). O volume utilizado foi de $5 \mu$ l o suficiente para embeber a tira de esponja de gelatina liofilizada de origem porcina de $1 \mathrm{~mm}$ de largura e $10 \mathrm{~mm}$ de comprimento (Hemospon Tape ${ }^{\circledR}$ - Technew, Rio de Janeiro, Brasil), sem que ocorresse extravazamento da solução. A utilização de esponjas de colágeno como carreadores para substâncias é frequentemente utilizada nas terapias de regeneração óssea (Calixto, Lima et al., 2011; Choi, Yun et al., 2012; De Brito Bezerra, Mendes Brazao et al., 2012; Olmos-Zuniga, Gonzalez-Lopez Md et al., 2012; Margolis, Wu et al., 2013).

\subsubsection{Da dosagem das citocinas}

A possíbilidade de mensurar mediadores solúveis envolvidos nos processos imunológicos vem sendo alvo dos pesquisadores nas ultimas décadas (Morgan, Varro et al., 2004). O conhecimento dos níveis destes mediadores nos tecidos em situações fisiológicas e patológicas nos permite entender o funcionamento da complexa rede de comunicação celular. Vários trabalhos na literatura mostram diferentes metodologias e reagentes comerciais para a realização destas medições (Pinna, Reimund et al., 2004; Ooi, Galatowicz et al., 2006; Yamasaki, Morimoto et al., 2006; Timmons, Hamadeh et al., 2009; Richens, Urbanowicz et al., 2010).

Para este trabalho optou-se pela utilização do CBA por ser possível detectar sete citocinas em uma mesma amostra de apenas $25 \mu \mathrm{l}$ do sobrenadante. Reduzindo desta forma a quantidade de animais utilizados, o tempo e o custo total da pesquisa. Na literatura é possível encontrar trabalhos, que confirmam esta afirmação além de comparar a metodologia empregada no teste CBA com a utilizada no teste imunoenzimático ELISA 
(Enzyme-Linked Immunosorbant Assay) onde pode-se constatar a concordância entre os resultados (Tarnok, Hambsch et al., 2003; Morgan, Varro et al., 2004; Pinna, Reimund et al., 2004; Jimenez, Ramirez et al., 2005; Ooi, Galatowicz et al., 2006; Timmons, Hamadeh et al., 2009).

\subsection{Dos Resultados}

\subsubsection{Grupos com a presença do LPS}

Em nossos estudos com o intuito de quantificar as citocinas das respostas Th1(IL-2, IL-6, TNF-a e IFN-y), Th2 (Il-4 e IL-6) e Th17 (Il-17) em uma condição semelhante ao encontrado na região periapical na presença de lesão inflamatória, optou-se por inocular juntamente com o cimento endodôntico o LPS bacteriano. Desta maneira era esperado um padrão de resposta inflamatória mais intensa quando comparado aos grupos controle. No entanto, a resposta esperada não ocorreu e os grupos onde os implantes continham o LPS apresentaram valores menores que os encontrados nos grupos controle. Como não se observaram resultados estatisticamente diversos daqueles obtidos com os grupos tratados com os cimentos sem a presença do LPS, optou-se por não apresenta-los neste estudo. Acredita-se que uma das razões para estes resultados esteja relacionada com o volume e concentração da solução de LPS utilizados, que podem ter sido insuficientes para gerar o padrão de resposta esperado.

Sant Anna, et al. (2008), após a implantação de tubos (2mm de diâmetro por $10 \mathrm{~mm}$ de comprimento) preenchidos com solução estéril de PBS e LPS de Echerichia coli na concentração de $10 \mathrm{mg} / \mathrm{ml}$ na região dorsal de camundongos, constataram, após os períodos esperimentais de 7, 15, e 30 dias, uma reação tecidual intensa nos tempos de 7 e 15 dias com a pesença de necrose, infiltrado inflamatório com neutrofilos, monócitos, vasodilatação e hemorragia. No período de 30 dias não foi observada a presença de necrose e o tecido mostrou-se com infiltrado inflamatório crônico. A diferenças encontradas neste trabalho em relação aos nossos estudos pode ser atribuída ao volume utilizado de aproximadamene 30 $\mu$ l que pode ter influenciado de forma positiva a resposta inflamatória. Ademais, é possível que o volume de 5 microlitros aplicados nesse estudo não tenha sido o suficiente para desencadear uma resposta inflamatória seguida da produçãoo de níveis de citocinas detectáveis pelo método CBA. 


\subsubsection{Grupos sem a presença do LPS}

Em nossos estudos o cimento AH-Plus ${ }^{\circledR}$ mostou-se capaz de inbir a liberação da citocina IL-2 no período de 7 dias quando comparado ao Activ-GP ${ }^{\circledR}(p=0,0391)$. Além disso, no período de 21 dias o $\mathrm{AH}^{-P l u s}{ }^{\circledR}$ promoveu a supressão da liberação da IL-2 quando comparado ao grupo controle $(p=0,0402)$ e ao cimento Sealapex ${ }^{\circledR}(p=0,0244)$ (Figura 32 Média e desvio padrão da citocina IL-2, nos diferentes grupos avaliados.). Sabendo-se do papel regulatório exercido pela IL-2 sobre os linfócitos T-helper e a presença predominante destes nas lesões periapicais em fase de expansão, supõe-se que a IL-2 desempenha um papel importante na inflamação periapical.

Yamasaki et al. (2006), avaliaram através de técnicas de imunohistoquímica os efeitos da supressão da citocina IL-2 na evolução da lesão periapical induzida em molares de ratos com 14 e 28 dias. Houve um aumento no número de células marcadas com o anticorpo anti-IL-2 aos 28 dias para o grupo controle e o mesmo não foi observado para o grupo teste. Ao avaliarem a progressão da lesão periapical, a inibição da IL-2 correlacionou-se com um aumento no tamanho da lesão nos dois períodos. Segundo os autores, a redução da IL-2 pode estar associada com a formação de lesões periapicais maiores por reduzir o número de linfócitos T-helper, diminuindo assim a capacidade de limitar a propagação periradicular das bactérias e produtos bacterianos. Sendo assim, é provável que o cimento AH-Plus ${ }^{\circledR}$ interfira na resposta imunológica nesses tipos de lesões por interferir na expansão de linfócitos $T$ induzidos pela IL-2.

Ao avaliar a liberação da citocina IL-6 em função da presença dos cimentos e períodos experimentais testados pode-se observar que o cimento AH-Plus ${ }^{\circledR}$ promoveu uma maior liberação desta citocina quando comparado ao Activ-GP ${ }^{\circledR}$ no período de $7(p=0,0286)$ e $21(p=0,0185)$ dias. Também ocorreu uma maior liberação quando comparado ao grupo controle no período de 21 ( $p=0,0149)$ dias. A citocina IL-6 apresenta um comportamento pleiotrópico, podendo atuar como pró-inflamatória e anti-inflamatória (Akira, Taga et al., 1993; Papanicolaou, Wilder et al., 1998). A IL-6 é considerada um dos fatores envolvidos na reabsorção óssea periapical (Martinho, Chiesa et al., 2012; Nibali, Fedele et al., 2012). Essa citocina pode ser produzida por osteoblastos frente o estímulo pelo paratormônio e, juntamente com a IL-3 induzem a formação de osteoclastos a partir de células precursora (Sugihara, Maeda et al., 1998). No entanto, animais IL-6 knockout apresentam maior progressão da lesão periapical associado aumento no número de osteoclastos (Huang, Do et al., 2001). É provável que tal achado, aparentemente controverso, tenha a ver com a regulação negativa que a IL-6 exerce sobre citocinas pró-inflamatórias como TNF-a e IL-1 
(alpha e beta) (principais ativadores de osteoclastos). Nesse trabalho, a expressão de IL-1ß foi encontrada aumentada nos animais IL-6 knockout. Outros trabalhos como o de Huang et al. (2001) reforçam a assertiva de que a lesão periapical em camundongos IL-6 knockout progride mais ao longo dos tempos operatórios comparando-se ao camundongo selvagem.

Em relação à cinética da IL-6, nossos resultados demonstraram que o pico de liberação de IL-6 ocorreu aos 7 dias (Figura 33 Média e desvio padrão da citocina IL-6, nos diferentes grupos avaliados.) e o cimento AH-Plus ${ }^{\circledR}$ promoveu um aumento de aproximadamente 3 vezes em relação ao nível basal. Além disso, aos 21 dias apenas o cimento Activ-GP ${ }^{\circledR}$ estava abaixo do nível basal e completados 63 dias todos os valores de todos os cimentos estavam abaixo do nível basal. Esses achados contradizem os achados de Kawashima et al. (1999) como os de Huang et al. (2001), que demonstraram que a produção de IL-6 teve seu pico 14 dias após a exposição da polpa em molares de camundongos, atingindo valores até 2 vezes maiores que o nível basal, voltando a níveis de normalidade somente após 28 dias. Obviamente, o retardo no pico de IL-6 demonstrados nos trabalhos supracitados tem relação com o tempo de necrose do tecido pulpar e 0 egresso de endotoxinas do canal radicular para os tecidos periapicais, após a exposição do tecido pulpar. No nosso caso, os cimentos testados já estão em contato direto com o tecido conjutivo subcutâneo o que torna a resposta mais rápida e, consequentemente, observandose os picos com 7 dias.

A existência de citocinas pró-inflamatórias como a IL-1 e o TNF-a que induzem a reabsorção óssea na lesão periapical já foi relatada por diversos autores (Stashenko, Yu et al., 1992; Wang, Tani-Ishii et al., 1997; Kawashima e Stashenko, 1999). Segundo Stashenko et al. (1998), a expressão do TNF-a ocorre no início da infecção sendo secretado em grande quantidade pelos macrófagos, bem como por outros tipos celulares, incluindo queratinócitos, fibroblastos, osteoblastos e osteoclástos. Em nossos achados podemos verificar que o pico de liberação do TNF-a ocorreu em 7 dias e apenas o cimento AH-Plus ${ }^{\circledR}$ foi estatísticamente superior em relação aos demais grupos (Figura 34 Média e desvio padrão da citocina TNF-a, nos diferentes grupos avaliados.).

Perassi et al. (2004), comparou a capacidade dos cimentos endodônticos Sealapex ${ }^{\circledR}$ e Endomethasone de estimular a liberação de TNF-a em cultura de células de macrófagos presentes no peritôneo de camundongos, utilizando-se 3 concentrações diferentes dos cimentos $(25,50,100 \mathrm{mg} / \mathrm{ml})$. Todas as soluções do cimento Sealapex ${ }^{\circledR}$ liberaram uma quantidade menor de TNF-a quando comparadas ao Endomethasone. Este resultados sugerem que a detecção de altos níves de TNF-a no período de 7 dias possa estar associada 
com a reação macrofágica frente a presença do cimento (Figura 34 Média e desvio padrão da citocina TNF-a, nos diferentes grupos avaliados.).

Em relação ao IFN- $\gamma$, pode-se observar em nossos resultados que aos 7 dias ocorreu um aumento de sua liberação em comparação ao nível basal para os grupos controle, Activ-GP ${ }^{\circledR}$, e AH-Plus ${ }^{\circledR}$. O grupo Sealapex ${ }^{\circledR}$ não apresentou aumento, sendo estatisticamente inferior ao grupo controle no período de 7 dias $(p=0,0007)$. Após 21 dias, os grupos controle e Sealapex ${ }^{\circledR}$ apresentaram aumento em relação ao período anterior e os grupos Activ-GP ${ }^{\circledR}$ e AH-Plus ${ }^{\circledR}$ apresentaram uma queda em suas concentrações, estando o grupo controle estatisticamente superior $(p=0,0193)$ ao AH-Plus ${ }^{\circledR}$ neste período. Aos 63 dias não foram detectadas diferenças entre os grupos e todos estavam abaixo do nível basal (Figura 35 Média e desvio padrão da citocina IFN- $\gamma$, nos diferentes grupos avaliados.).

De Rossi et al. (2008) avaliaram os efeitos da citocina IFN- $\gamma$, no desenvolvimento da lesão periapical induzida em camundongos selvagens e knockout nos períodos de 7, 21 e 42 dias. Seus resultados mostraram a presença de lesões maiores nos animais knockout em relação ao grupo controle, sugerindo que o IFN-y possui um efeito protetor nas fases mais tardias da reabsorção óssea periapical in vivo. Esses dados estão em concordância com nosso trabalho pois houve um pico de liberação do IFN-y aos 21 dias em nosso grupo controle (Figura 35 Média e desvio padrão da citocina IFN-Y, nos diferentes grupos avaliados.).

Os mecanismos de reabsorção óssea nas lesões periapicais são regulados pelas citocinas pró-inflamatórias Th1 e anti-inflamatórias Th2, modulando a expressão da IL-1 e TNF-a que estimulam a osteoclastogênese, sendo que as principais citocinas da resposta Th2 são a IL-4 e IL-10. Ao verificar o papel de cada uma delas na modulação da destruição óssea os pesquisadores Sasaki et al. (2000), e De Rossi et al. (2008), induziram a formação de lesões periapicais em animais knockout e compararam o tamanho das lesões com os animais controle. Em ambos os trabalhos foi constatado que a IL-4 não possui capacidade de suprimir o desenvolvimento da lesão e a IL-10 no entanto possui a capacidade de atenuar a sua evolução.

Em nosso trabalho podemos observar em todos os grupos a predominância da resposta Th1 no período de 7 dias juntamente com aumento das concentrações de IL-6 e TNF-a coincidindo com a fase aguda da inflamação. Já aos 21 dias ocorreu a maior liberação de citocinas relacionadas com a resposta Th2, onde observamos os picos de IL-4 e IL-10. Simultaneamente observamos uma tendência de cronificação ou reparo da lesão, com a diminuição dos níveis de IL-6 e TNF-a (Figuras 32,33,34,35,36 e 37). 
A IL-17 é produzida basicamente por uma nova classe de células $\mathrm{T}$ ativadas denominadas Th17. Esta citocina é considerada uma citocina pró-inflamatória, com efeito em diversas células da resposta inata (Kolls e Linden, 2004; Dong, 2006). O papel por ela desempenhado na lesão periapical foi estudado por Oseko et al. (2009), que utilizou linhagens knockout para IL-17A para induzir a formação de lesão periapical em um período de 21 dias. Após esse período os animais foram sacrificados e o tamanho das lesões avaliados. Os animais knockout para IL-17 apresentaram lesões menores que os animais selvagens, concluindo-se que a IL-17 possui um papel importante na formação da lesão periapical. Xiong et al. (2009), quantificaram através de imunohistoquímica as células positivas para IL-17 em lesões periapicais de camundongos nos períodos de 0, 7, 14, 21 e 28 dias bem como a presença de osteoclastos. Foi possível observar o aumento do número de células marcadas para IL-17 ao longo dos tempos experimentais atingindo-se o pico aos 28 dias. A quantidade de osteoclastos subiu consideravelmente até o dia 14, diminuindo gradativamente até o dia 28. Estes resultados sugeriram que a IL-17 pode estar envolvida tanto na resposta inflmatória quanto no processo de reabsorção óssea no periápice.

Em nosso resultados a citocina IL-17 mostrou um comportamento diferente para cada grupo avaliado. Aos 7 dias todos os grupos apresentavam valores maiores que o nível basal, mas sem diferenças estatísticas entre eles. Com 21 dias os grupos controle e Selalapex atingiram o pico de suas concentrações e apresentaram diferenças estatísticas para o grupo AH-Plus ${ }^{\circledR}$. O grupo Acitv-GP ${ }^{\circledR}$ foi estatiticamente inferior ao controle no período de 21 dias. Ainda foi possível observar que os grupos Acitv-GP ${ }^{\circledR}$ e AH-Plus ${ }^{\circledR}$ tiveram redução da IL-17 aos 21 dias em relação ao período anterior. Já com 63 dias houve a redução dos valores de IL-17 para os grupos controle e Sealapex ${ }^{\circledR}$ e ocorreu o aumento dos valores para os grupos Activ-GP ${ }^{\circledR}$ e AH-Plus ${ }^{\circledR}$ (Figura 38 Média e desvio padrão da citocina IL-17, nos diferentes grupos avaliados.). Assim como no trabalho de Xiong et al. (2009), podemos afirmar que a IL-17 está envolvida do processo inflamatório, tendo o seu pico aos 28 dias. No entanto, o modelo utilizado nesse trabalho não deixa claro seu real papel no desenvolvimento das lesões periapicais, sendo necessário estudos adicionais.

Com relação aos cimentos e citocinas avaliados neste estudo, observou-se que estes materiais tem a capacidade de interferir positiva ou negativamente na produção e liberação das citocinas, na medida em que eles entram em contato com o tecido subcutâneo.

O grupo AH-Plus ${ }^{\circledR}$ influenciou muito o perfil de resposta Th1. Pôde-se observar que ocorreu a inibição da liberação de IL-2 aos 7 dias, um pico de liberação da IL-6 aos 7 dias e após 21 dias ainda apresentava valores superiores aos grupos controle e Activ-GP ${ }^{\circledR}$, com diferenças estatisticamente significantes. Os valores obtidos para TNF-a no grupo AH-Plus ${ }^{\circledR}$, 
também apresentaram diferenças estatisticamente significantes em relação aos demais grupos no período de 7 dias. A citocina IFN-y teve sua liberação inibida pelo cimento $\mathrm{AH}-$ Plus $^{\circledR}$ em relação ao grupo controle no período de 21 dias.

Portanto, podemos afirmar que em nosso modelo experimental asséptico o cimento AH-Plus ${ }^{\circledR}$ modulou a resposta das citocinas pró-inflamatórias Th1. No, entanto, devemos salientar que as citocinas possuem efeitos pleiotrópicos, o que nos impede de afirmar se esse fenômeno auxiliaria ou não na destruição dos antígenos egressos quando pensamos no contexto da inflamação periapical.

Ao analisarmos os grupos controle, Sealapex ${ }^{\circledR}$ e Activ-GP ${ }^{\circledR}$ observamos 0 predomínio de uma resposta Th1 aos 7 dias e Th2 em 21 dias. Após 63 dias, observou-se a cronificação ou reparo do processo.

Com relação à resposta Th-17, esta foi mais acentuada aos 21 dias para o grupo controle e Sealapex ${ }^{\circledR}$ e os grupos Activ-GP ${ }^{\circledR}$ e AH-Plus ${ }^{\circledR}$ tiveram os menores valores de resposta aos 21 dias. 

Conclusão 



\section{CONCLUSÃo}

Com base nos resultados obtidos conclui-se que:

1. Os cimentos testados foram capazes de modular as respostas Th1, Th2, Th17 através da inibição ou estimulação da liberação das citocinas testadas.

2. O cimento Sealapex ${ }^{\circledR}$ apresentou um comportamento semelhante ao grupo controle com relação as citocinas avaliadas.

3. O cimento AH-Plus ${ }^{\circledR}$ promoveu as maiores diferenças no perfil de resposta Th1 para as citocinas IL-2, IL-6 e IFN- $\gamma$ aos 21 dias e para TNF-a aos 7 dias. 

Referências 



\section{REFERENCIAS}

Abbas, A. K. L., A.H.; Pillai, S. Imunologia celular e molecular. Rio de Janeiro: Elsevier. 2008

Aggarwal, S. e A. L. Gurney. IL-17: prototype member of an emerging cytokine family. J Leukoc Biol, v.71, n.1, Jan, p.1-8. 2002.

Akira, S., T. Taga, et al. Interleukin-6 in biology and medicine. Adv Immunol, v.54, p.1-78. 1993.

Ansel, K. M., D. U. Lee, et al. An epigenetic view of helper T cell differentiation. Nat Immunol, v.4, n.7, Jul, p.616-23. 2003.

Baldwin, L. e J. A. Hunt. The in vivo cytokine release profile following implantation. Cytokine, v.41, n.3, Mar, p.217-22. 2008.

Bernath, M. e J. Szabo. Tissue reaction initiated by different sealers. Int Endod J, v.36, n.4, Apr, p.256-61. 2003.

Bilginer, S., T. Esener, et al. The investigation of biocompatibility and apical microleakage of tricalcium phosphate based root canal sealers. J Endod, v.23, n.2, Feb, p.105-9. 1997.

Block, R. M., A. Bushell, et al. A histopathologic, histobacteriologic, and radiographic study of periapical endodontic surgical specimens. Oral Surg Oral Med Oral Pathol, v.42, n.5, Nov, p.656-78. 1976.

Bortoluzzi, E. A. Avaliação da reação do tecido subcutâneo de ratos à implantação dos cimentos MTA e Portland brancos acrescidos de radiopacificadores. (Dissertação). Faculdade de Odontologia de Bauru, Universidade de São Paulo, Bauru, 2005. 175 p.

Calixto, J. C., C. E. Lima, et al. The influence of local administration of simvastatin in calvarial bone healing in rats. J Craniomaxillofac Surg, v.39, n.3, Apr, p.215-20. 2011.

Choi, Y., J. H. Yun, et al. Sinus augmentation using absorbable collagen sponge loaded with Escherichia coli-expressed recombinant human bone morphogenetic protein 2 in a standardized rabbit sinus model: a radiographic and histologic analysis. Clin Oral Implants Res, v.23, n.6, Jun, p.682-9. 2012.

Coico, R. S., Geoffrey. Imunologia. Rio de Janeiro: Guanabara Koogan. 2010

Colic, M., D. Gazivoda, et al. Proinflammatory and immunoregulatory mechanisms in periapical lesions. Mol Immunol, v.47, n.1, Nov, p.101-13. 2009.

Colic, M., S. Vasilijic, et al. Interleukin-17 plays a role in exacerbation of inflammation within chronic periapical lesions. Eur J Oral Sci, v.115, n.4, Aug, p.315-20. 2007. 
Commins, S. P., L. Borish, et al. Immunologic messenger molecules: cytokines, interferons, and chemokines. J Allergy Clin Immunol, v.125, n.2 Suppl 2, Feb, p.S53-72. 2010.

Consolaro, A. Inflamação e Reparo: um sílabo para a compreemsão clínica e implicações terapeuticas. Maringá: Dental Press. 2009

Da Silva, L. A., R. A. Da Silva, et al. Quantitative radiographic evaluation of periapical bone resorption in dog's teeth contaminated with bacterial endotoxin (LPS) associated or not with calcium hydroxide. Braz Dent J, v.19, n.4, p.296-300. 2008.

De Brito Bezerra, B., M. A. Mendes Brazao, et al. Association of hyaluronic acid with a collagen scaffold may improve bone healing in critical-size bone defects. Clin Oral Implants Res, v.23, n.8, Aug, p.938-42. 2012.

De Oliveira Mendes, S. T., A. P. Ribeiro Sobrinho, et al. In vitro evaluation of the cytotoxicity of two root canal sealers on macrophage activity. J Endod, v.29, n.2, Feb, p.95-9. 2003.

De Oliveira, R. L., R. S. Oliveira Filho, et al. Influence of calcium hydroxide addition to AH Plus sealer on its biocompatibility. Oral Surg Oral Med Oral Pathol Oral Radiol Endod, v.109, n.1, Jan, p.e50-4. 2010.

De Rossi, A., L. B. Rocha, et al. Interferon-gamma, interleukin-10, Intercellular adhesion molecule-1, and chemokine receptor 5 , but not interleukin-4, attenuate the development of periapical lesions. J Endod, v.34, n.1, Jan, p.31-8. 2008.

Dong, C. Diversification of T-helper-cell lineages: finding the family root of IL-17-producing cells. Nat Rev Immunol, v.6, n.4, Apr, p.329-33. 2006.

Dwyer, T. G. e M. Torabinejad. Radiographic and histologic evaluation of the effect of endotoxin on the periapical tissues of the cat. J Endod, v.7, n.1, Jan, p.31-5. 1981.

Farhad, A. R., S. Hasheminia, et al. Histopathologic evaluation of subcutaneous tissue response to three endodontic sealers in rats. J Oral Sci, v.53, n.1, p.15-21. 2011.

Figueiredo, J. A., H. F. Pesce, et al. The histological effects of four endodontic sealers implanted in the oral mucosa: submucous injection versus implant in polyethylene tubes. Int Endod J, v.34, n.5, Jul, p.377-85. 2001.

Fouad, A. F. e A. W. Acosta. Periapical lesion progression and cytokine expression in an LPS hyporesponsive model. Int Endod J, v.34, n.7, Oct, p.506-13. 2001.

Gaffen, S. L., J. M. Kramer, et al. The IL-17 cytokine family. Vitam Horm, v.74, p.255-82. 2006. 
Gomes-Filho, J. E., P. F. Bernabe, et al. Reaction of rat connective tissue to a new calcium hydroxide-based sealer. Oral Surg Oral Med Oral Pathol Oral Radiol Endod, v.106, n.2, Aug, p.e71-6. 2008.

Gomes-Filho, J. E., A. C. Gomes, et al. Evaluation of tissue reaction, cell viability and cytokine production induced by Sealapex Plus. J Appl Oral Sci, Jun 3. 2011.

Gomes-Filho, J. E., S. Watanabe, et al. Evaluation of the effects of endodontic materials on fibroblast viability and cytokine production. J Endod, v.35, n.11, Nov, p.1577-9. 2009.

Grossman, L. I. Physical properties of root canal cements. J Endod, v.2, n.6, Jun, p.166-75. 1976.

Holland, R. e V. De Souza. Ability of a new calcium hydroxide root canal filling material to induce hard tissue formation. J Endod, v.11, n.12, Dec, p.535-43. 1985.

Hong, C. Y., S. K. Lin, et al. The role of lipopolysaccharide in infectious bone resorption of periapical lesion. J Oral Pathol Med, v.33, n.3, Mar, p.162-9. 2004.

Huang, G. T., M. Do, et al. Effect of interleukin-6 deficiency on the formation of periapical lesions after pulp exposure in mice. Oral Surg Oral Med Oral Pathol Oral Radiol Endod, v.92, n.1, Jul, p.83-8. 2001.

Iso10993-6, I. S. Biological evalution of medical devices - Part 6: Test for local effects after implantation: 1-21 p. 2007.

Jimenez, R., R. Ramirez, et al. Cytometric bead array (CBA) for the measurement of cytokines in urine and plasma of patients undergoing renal rejection. Cytokine, v.32, n.1, Oct 7, p.45-50. 2005.

Kawashima, N. e P. Stashenko. Expression of bone-resorptive and regulatory cytokines in murine periapical inflammation. Arch Oral Biol, v.44, n.1, Jan, p.55-66. 1999.

Kettering, J. D. e M. Torabinejad. Presence of natural killer cells in human chronic periapical lesions. Int Endod J, v.26, n.6, Nov, p.344-7. 1993.

Khashaba, R. M., M. M. Moussa, et al. The response of subcutaneous connective tissue to newly developed calcium phosphate-based root canal sealers. Int Endod J, v.44, n.4, Apr, p.342-52. 2011.

Kolls, J. K. e A. Linden. Interleukin-17 family members and inflammation. Immunity, v.21, n.4, Oct, p.467-76. 2004.

Leonardo, M. R., R. A. Silva, et al. Importance of bacterial endotoxin (LPS) in endodontics. J Appl Oral Sci, v.12, n.2, Jun, p.93-8. 2004. 
Leonardo, M. R. L., J.M. Endodontia. Tratamento dos Canais Radiculares. São Paulo. 1991

Margolis, D. S., E. W. Wu, et al. Axonal loss in murine peripheral nerves following exposure to recombinant human bone morphogenetic protein-2 in an absorbable collagen sponge. J Bone Joint Surg Am, v.95, n.7, Apr 3, p.611-9. 2013.

Martinho, F. C., W. M. Chiesa, et al. Correlation between clinical/radiographic features and inflammatory cytokine networks produced by macrophages stimulated with endodontic content. J Endod, v.38, n.6, Jun, p.740-5. 2012.

Marton, I. J. e C. Kiss. Protective and destructive immune reactions in apical periodontitis. Oral Microbiol Immunol, v.15, n.3, Jun, p.139-50. 2000.

Matsushita, K., T. Tajima, et al. Inflammatory cytokine production and specific antibody responses to lipopolysaccharide from endodontopathic black-pigmented bacteria in patients with multilesional periapical periodontitis. J Endod, v.25, n.12, Dec, p.795-9. 1999.

Maurício, C. V., R. C. Comelli Lia, et al. Estudo histomorfológico do tecido conjuntivo subcutâneo do rato ao implante de pastas à base de hidróxido de cálcio, contidas em tubos de dentina humana. Rev Odont UNESP, v.15/16, p.23-38. 1986.

Moraes, F. G. D. Biocompatibilidade dos cimentos Sealer 26 e Óxido de Zinco e Eugenosl protegidos ou não com dois diferentes tipos de própolis. Análise em tecido subcutâneo de ratos. (Dissertação). Faculdade de Odontologia de Bauru, Universidade de São Paulo, Bauru, 2005.

Morgan, E., R. Varro, et al. Cytometric bead array: a multiplexed assay platform with applications in various areas of biology. Clin Immunol, v.110, n.3, Mar, p.252-66. 2004.

Nair, P. N. Apical periodontitis: a dynamic encounter between root canal infection and host response. Periodontol 2000, v.13, Feb, p.121-48. 1997.

Nair, S. P., S. Meghji, et al. Bacterially induced bone destruction: mechanisms and misconceptions. Infect Immun, v.64, n.7, Jul, p.2371-80. 1996.

Nassri, M. R., R. C. Lia, et al. [Analysis of the tissue answer regarding two root canal sealers.]. J Appl Oral Sci, v.11, n.1, Mar, p.9-14. 2003.

Nelson-Filho, P., M. R. Leonardo, et al. Radiographic evaluation of the effect of endotoxin (LPS) plus calcium hydroxide on apical and periapical tissues of dogs. J Endod, v.28, n.10, Oct, p.694-6. 2002.

Nibali, L., S. Fedele, et al. Interleukin-6 in oral diseases: a review. Oral Dis, v.18, n.3, Apr, p.236-43. 2012. 
Olmos-Zuniga, J. R., R. Gonzalez-Lopez Md, et al. Effects of middle ear packing with collagen polyvinylpyrrolidone and hyaluronic acid in guinea pigs. J Invest Surg, v.25, n.6, Dec, p.398404. 2012.

Olsson, B., A. Sliwkowski, et al. Subcutaneous implantation for the biological evaluation of endodontic materials. J Endod, v.7, n.8, Aug, p.355-67. 1981.

Ooi, K. G., G. Galatowicz, et al. Multiplex cytokine detection versus ELISA for aqueous humor: IL-5, IL-10, and IFNgamma profiles in uveitis. Invest Ophthalmol Vis Sci, v.47, n.1, Jan, p.272-7. 2006.

Oseko, F., T. Yamamoto, et al. IL-17 is involved in bone resorption in mouse periapical lesions. Microbiol Immunol, v.53, n.5, May, p.287-94. 2009.

Ozbas, H., M. Yaltirik, et al. Reactions of connective tissue to compomers, composite and amalgam root-end filling materials. Int Endod J, v.36, n.4, Apr, p.281-7. 2003.

Papanicolaou, D. A., R. L. Wilder, et al. The pathophysiologic roles of interleukin-6 in human disease. Ann Intern Med, v.128, n.2, Jan 15, p.127-37. 1998.

Paul, W. Imunologia Fundamental. Philadelphia: Lippincott-Raven. 1999

Paula-Silva, F. W., L. A. Da Silva, et al. Matrix metalloproteinase expression in teeth with apical periodontitis is differentially modulated by the modality of root canal treatment. J Endod, v.36, n.2, Feb, p.231-7. 2010.

Perassi, F. T., I. B. Filho, et al. Secretion of tumor necrosis factor-alpha by mouse peritoneal macrophages in the presence of dental sealers, sealapex and endomethasone. J Endod, v.30, n.7, Jul, p.534-7. 2004.

Pinna, G., J. M. Reimund, et al. [How to test at once six cytokines in samples as small as 25 microl?]. Ann Biol Clin (Paris), v.62, n.1, Jan-Feb, p.59-63. 2004.

Queiroz, A. M., S. Assed, et al. Subcutaneous connective tissue response to primary root canal filling materials. Braz Dent J, v.22, n.3, p.203-11. 2011.

Richens, J. L., R. A. Urbanowicz, et al. Quantitative validation and comparison of multiplex cytokine kits. J Biomol Screen, v.15, n.5, Jun, p.562-8. 2010.

Rietschel, E. T. e H. Brade. Bacterial endotoxins. Sci Am, v.267, n.2, Aug, p.54-61. 1992.

Rocha, C. T., M. A. Rossi, et al. Biofilm on the apical region of roots in primary teeth with vital and necrotic pulps with or without radiographically evident apical pathosis. Int Endod J, v.41, n.8, Aug, p.664-9. 2008. 
Rossi, D. e A. Zlotnik. The biology of chemokines and their receptors. Annu Rev Immunol, v.18, p.217-42. 2000.

Sant'anna, A. T., L. C. Spolidorio, et al. Histological analysis of the association between formocresol and endotoxin in the subcutaneous tissue of mice. Braz Dent J, v.19, n.1, p.405. 2008.

Sasaki, H., L. Hou, et al. IL-10, but not IL-4, suppresses infection-stimulated bone resorption in vivo. J Immunol, v.165, n.7, Oct 1, p.3626-30. 2000.

Silva-Herzog, D., T. Ramirez, et al. Preliminary study of the inflammatory response to subcutaneous implantation of three root canal sealers. Int Endod J, v.44, n.5, May, p.440-6. 2011.

Silva, L., P. Nelson-Filho, et al. Effect of calcium hydroxide on bacterial endotoxin in vivo. J Endod, v.28, n.2, Feb, p.94-8. 2002.

Silva, L. A., M. R. Leonardo, et al. Inflammatory response to calcium hydroxide based root canal sealers. J Endod, v.23, n.2, Feb, p.86-90. 1997.

Silva, T. A., G. P. Garlet, et al. Chemokines in oral inflammatory diseases: apical periodontitis and periodontal disease. J Dent Res, v.86, n.4, Apr, p.306-19. 2007.

Silveira, C. M., S. C. Pinto, et al. Biocompatibility of four root canal sealers: a histopathological evaluation in rat subcutaneous connective tissue. Braz Dent J, v.22, n.1, p.21-7. 2011.

Sousa, C. J., A. M. Loyola, et al. A comparative histological evaluation of the biocompatibility of materials used in apical surgery. Int Endod J, v.37, n.11, Nov, p.738-48. 2004.

Sousa, C. J., C. R. Montes, et al. Comparison of the intraosseous biocompatibility of AH Plus, EndoREZ, and Epiphany root canal sealers. J Endod, v.32, n.7, Jul, p.656-62. 2006.

Stashenko, P., F. E. Dewhirst, et al. Synergistic interactions between interleukin 1, tumor necrosis factor, and lymphotoxin in bone resorption. J Immunol, v.138, n.5, Mar 1, p.1464-8. 1987.

Stashenko, P., R. Teles, et al. Periapical inflammatory responses and their modulation. Crit Rev Oral Biol Med, v.9, n.4, p.498-521. 1998.

Stashenko, P., S. M. Yu, et al. Kinetics of immune cell and bone resorptive responses to endodontic infections. J Endod, v.18, n.9, Sep, p.422-6. 1992. 
Sugihara, A., O. Maeda, et al. Expression of cytokines enhancing the osteoclast activity, and parathyroid hormone-related protein in prostatic cancers before and after endocrine therapy: an immunohistochemical study. Oncol Rep, v.5, n.6, Nov-Dec, p.1389-94. 1998.

Takahashi, K. Microbiological, pathological, inflammatory, immunological and molecular biological aspects of periradicular disease. Int Endod J, v.31, n.5, Sep, p.311-25. 1998.

Takahashi, K., T. Azuma, et al. The potential role of interleukin-17 in the immunopathology of periodontal disease. J Clin Periodontol, v.32, n.4, Apr, p.369-74. 2005.

Tarnok, A., J. Hambsch, et al. Cytometric bead array to measure six cytokines in twenty-five microliters of serum. Clin Chem, v.49, n.6 Pt 1, Jun, p.1000-2. 2003.

Tayal, V. e B. S. Kalra. Cytokines and anti-cytokines as therapeutics--an update. Eur J Pharmacol, v.579, n.1-3, Jan 28, p.1-12. 2008.

Timmons, B. W., M. J. Hamadeh, et al. Two methods for determining plasma IL-6 in humans at rest and following exercise. Eur J Appl Physiol, v.105, n.1, Jan, p.13-8. 2009.

Torneck, C. D. Reaction of rat connective tissue to polyethylene tube implants. I. Oral Surg Oral Med Oral Pathol, v.21, n.3, Mar, p.379-87. 1966.

Valera, M. C., M. R. Leonardo, et al. Biological compatibility of some types of endodontic calcium hydroxide and glass ionomer cements. J Appl Oral Sci, v.12, n.4, Dec, p.294-300. 2004.

Veloso, H. H., R. A. Do Santos, et al. Histological analysis of the biocompatibility of three different calcium hydroxide-based root canal sealers. J Appl Oral Sci, v.14, n.5, Oct, p.37681. 2006.

Wang, C. Y., N. Tani-Ishii, et al. Bone-resorptive cytokine gene expression in periapical lesions in the rat. Oral Microbiol Immunol, v.12, n.2, Apr, p.65-71. 1997.

$\mathrm{Wu}, \mathrm{Y} ., \mathrm{L}$. Zhu, et al. Regulation of matrix metalloproteinases, tissue inhibitor of matrix metalloproteinase-1, and extracellular metalloproteinase inducer by interleukin-17 in human periodontal ligament fibroblasts. J Endod, v.39, n.1, Jan, p.62-7. 2013.

Xiong, H., L. Wei, et al. Immunohistochemical localization of IL-17 in induced rat periapical lesions. J Endod, v.35, n.2, Feb, p.216-20. 2009.

Yamanaka, Y., Y. Shigetani, et al. Immunohistochemical analysis of subcutaneous tissue reactions to methacrylate resin-based root canal sealers. Int Endod J, Mar 6. 2011.

Yamasaki, M., T. Morimoto, et al. Role of IL-2 and helper T-lymphocytes in limiting periapical pathosis. J Endod, v.32, n.1, Jan, p.24-9. 2006. 

Anexo 



\title{
ANEXo
}

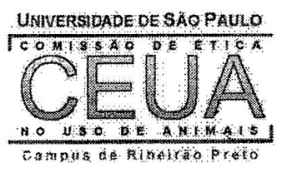

\author{
UNIVERSIDADE DE SÃO PAULO \\ Campus de Ribeirão Preto \\ Comissão de Ética no Uso de Animais
}

\section{E R T I F I C A D O}

Certificamos que o trabalho (Protocolo $n^{\circ}$ 11.1.1455.53.5), intitulado "Avaliação da Liberação de Citocinas no Tecido Subcutâneo de Camundongos na Presença de Cimento Endodôntico com e sem a Estimulação por LPS Bacteriano", de autoria de Leonardo Bíscaro Pereira, e de Mário Roberto Leonardo por estar de acordo com os Princípios Éticos na Experimentação Animal adotado pela Comissão de Ética no Uso de Animais (CEUA) do Campus de Ribeirão Preto - USP foi aprovado em reunião da CEUA de 07/03/2012.

Colaboradores: Marcelo José Barbosa silva

This is to certify that the work (Protocol number 11.1.1455.53.5), entitled: "Avaliação da Liberação de Citocinas no Tecido Subcutâneo de Camundongos na Presença de Cimento Endodôntico com e sem a Estimulação por LPS Bacteriano", by Leonardo Bíscaro Pereira and Mário Roberto Leonardo, is in accordance with the Ethic Principles in Animal Experimentation adopted by Ethic Commission for the Use of Animals (CEUA) of the Campus of Ribeirão Preto - USP, and was approved in the meeting, March 07, 2012.

Ribeirão Preto, 13 de março de 2012.

Presidente da CEUA

Profa.Dra. Claudia Maria Padovan

Secretária da CEUA

Maria Angélica Depiro

Recebi o originat Dats $22,3,12$

Av. Bandeirantes, 3900 - CEP 14040-900 - Ribeirão Preto - São Paulo Fone: (16) 36024469 - Fax: (16) 36337964 